UNIVERSIDADE DE BRASÍLIA

PÓS-GRADUAÇÃO EM GEOGRAFIA

AVALIAÇÃO DA QUALIDADE DA ÁGUA DO LENÇOL FREÁTICO E SUA CORRELAÇÃO COM O USO E OCUPAÇÃO DA TERRA NA BACIA DO ALTO RIO JARDIM (DF)

Luane Souza de Araújo

Dissertação de Mestrado 

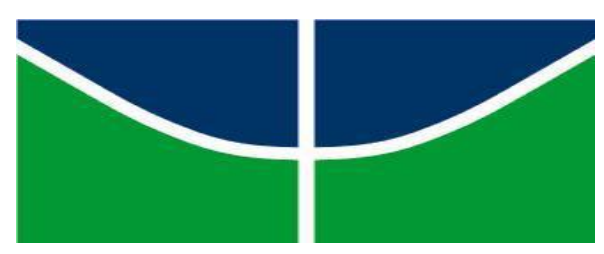

Universidade de Brasília

Instituto de Ciências Humanas

Departamento de Geografia

Programa de Pós-Graduação em Geografia

UNIVERSIDADE DE BRASÍLIA

PÓS-GRADUAÇÃO EM GEOGRAFIA

\section{AVALIAÇÃO DA QUALIDADE DA ÁGUA DO LENÇOL FREÁTICO E SUA CORRELAÇÃO COM O USO E OCUPAÇÃO DA TERRA NA BACIA DO ALTO RIO JARDIM (DF)}

LUANE SOUZA DE ARAÚJO

Orientador: $\operatorname{Prof}^{\circ} \operatorname{Dr}^{\circ}$ Roberto Arnaldo Trancoso Gomes

Coorientador: Dr ${ }^{\circ}$ Jorge Enoch Furquim Werneck Lima

Dissertação de Mestrado

Brasília/DF: Outubro/2016 
UNIVERSIDADE DE BRASÍLIA

PÓS-GRADUAÇÃO EM GEOGRAFIA

\section{AVALIAÇÃO DA QUALIDADE DA ÁGUA DO LENÇOL FREÁTICO E SUA CORRELAÇÃO COM O USO E OCUPAÇÃO DA TERRA NA BACIA DO \\ ALTO RIO JARDIM (DF)}

Luane Souza de Araújo

Dissertação de Mestrado submetida ao Departamento de Geografia da Universidade de Brasília, como parte dos requisitos necessários para a obtenção do Grau de Mestre em Geografia, área de concentração Gestão Ambiental e Territorial, opção Acadêmica.

Aprovado por:

Roberto Arnaldo Trancoso Gomes, Doutor (Geografia - UnB)

(Orientador)

Jorge Enoch Furquim Werneck Lima, Doutor (Embrapa Cerrados)

(Coorientador)

Potira Meirelles Hermuche, Doutora (Geografia - UnB)

(Examinadora Externa)

Lenora Nunes Ludolf Gomes, Doutora (Engenharia Civil e Ambiental- UnB)

(Examinadora Interna)

Brasília/DF, 07 de Outubro de 2016. 
ARAÚJO, LUANE SOUZA DE

AVALIAÇÃO DA QUALIDADE DA ÁGUA DO LENÇOL FREÁTICO E SUA CORRELAÇÃO COM O USO E OCUPAÇÃO DA TERRA NA BACIA DO ALTO RIO JARDIM (DF). 83p. (UnB-IH-GEA, Mestre, Gestão Ambiental e Territorial, 2016).

Dissertação de Mestrado - Universidade de Brasília. Departamento de Geografia.

1. Água subterrânea 2. Uso e ocupação da terra

3. Agricultura 4. Cerrado

5. Regressão Quadrática Múltipla

$\begin{array}{ll}\text { I. UnB - IH - GEA } & \text { II. Título (série) }\end{array}$

\section{REFERÊNCIA BIBLIOGRÁFICA}

ARAÚJO, LUANE SOUZA DE. Avaliação da qualidade da água do lençol freático e sua correlação com o uso e ocupação da terra na Bacia do Alto Rio Jardim (DF). Dissertação de Mestrado, Curso de Pós-Graduação em Geografia, Universidade de Brasília, Brasília, 2016, 83p.

\section{CESSÃO DE DIREITOS}

É concedida à Universidade de Brasília permissão para reproduzir cópias desta dissertação e emprestar ou vender tais cópias somente para propósitos acadêmicos e científicos. A autora reserva outros direitos de publicação e nenhuma parte desta dissertação de mestrado pode ser reproduzida sem a autorização por escrito da autora.

Luane Souza de Araújo

Brasília/DF, Outubro de 2016. 


\section{AGRADECIMENTOS}

Ao professor Roberto por todo apoio, paciência e ensinamentos ao longo da dissertação, que mesmo longe se fez presente, sempre me auxiliando.

Ao pesquisador Jorge Enoch, da Embrapa Cerrados, pelos ensinamentos, por incentivar meu ingresso no mestrado, pela confiança no meu trabalho e pela disponibilização de recursos, estrutura, equipe e dados de seus projetos (Projeto Chuva-Vazão, Cooperação Embrapa Cerrados - Fundo Clima/MMA) para a realização deste trabalho.

À Daphne Muniz e ao pesquisador Eduardo Cyrino, pela ajuda imprescindível na análise química das amostras e por toda a experiência transmitida.

Ao Juaci Malaquias pelo auxílio na etapa estatística da dissertação.

Aos técnicos da Embrapa Cerrados José Roberto (Jatobá) e Luciano Adjuto pela caminhada ao longo do ano de coleta dos dados, tornando o trabalho de campo bem descontraído.

Aos estagiários do Laboratório de Hidrometria e Hidrossedimentometria da Embrapa Cerrados Nikolas, Leonardo, Pedro e Leonardo pelo auxílio nas coletas; e ao Alexandre e à Zélia pelo auxílio nas dúvidas em geoprocessamento.

Ao professor Osmar pela ajuda na resolução das questões burocráticas e pelo incentivo.

Aos colegas do Laboratório de Sistemas de Informações Espaciais da Unb, Nathália, Nickolas, Miriam, Verônica e Maria pelo apoio nos momentos difíceis, pelas trocas de conhecimento, auxílio constante, pela força transmitida e pelos momentos de diversão.

À minha família pelo incentivo aos meus estudos.

Ao Kim pela enorme paciência, apoio, palavras de ânimo e companheirismo.

Às minhas amigas Jana, Keyci, Luiza e Sarah pela parceria incrível e apoio incondicional.

E agradeço imensamente a Deus, pela força me dada em todos os momentos, e por estar sempre presente em minha caminhada.

A todos, o meu muito obrigada! 


\section{RESUMO}

Araújo, Luane Souza de. Avaliação da qualidade da água do lençol freático e sua correlação com o uso e ocupação da terra na bacia do alto Rio Jardim (DF). 2016. 83p. Dissertação (Mestrado) - Programa de Pós-Graduação em Geografia, Universidade de Brasília, Brasília, 2016.

O uso e ocupação da terra vêm sendo alterado com tempo e modificando os espaços naturais. A expansão agrícola é um dos agentes de tais mudanças. Diante disso, há necessidade de avaliar seus impactos, mais especificamente no que se refere aos recursos hídricos. Deste modo, o objetivo deste estudo foi avaliar os impactos exercidos pelo uso e ocupação da terra na qualidade da água do lençol freático em área agrícola, no Distrito Federal. O estudo foi realizado por meio da análise da qualidade da água de 38 poços piezométricos distribuídos pela área de estudo, a Bacia Experimental do Alto Rio Jardim (BEARJ). Foram coletadas amostras mensalmente durante o período de julho de 2014 até junho de 2015. As variáveis analisadas foram condutividade elétrica (CE), sólidos dissolvidos totais (SDT), pH, alcalinidade, bicarbonato, dureza total, fósforo solúvel (Ps); íons: cloreto $\left(\mathrm{Cl}^{-}\right)$, fluoreto $\left(\mathrm{F}^{-}\right)$, nitrato $\left(\mathrm{NO}_{3}{ }^{-}\right)$, sódio $\left(\mathrm{Na}^{+}\right)$, potássio $\left(\mathrm{K}^{+}\right)$, cálcio $\left(\mathrm{Ca}^{2+}\right)$, magnésio $\left(\mathrm{Mg}^{2+}\right)$ e sulfato $\left(\mathrm{SO}_{4}{ }^{2-}\right)$. Realizou se a delimitação das áreas de drenagem de cada poço utilizando a ferramenta TauDEM, assim como o mapeamento de uso e ocupação da terra da bacia hidrográfica. Os dados foram analisados por meio da estatística descritiva; da comparação dos valores medidos com os valores de referência da legislação CONAMA nº 396/2008 para Classe 1 e 2, além dos modelos de regressão quadrática múltipla, envolvendo 16 variáveis independes. Os resultados indicam que a qualidade da água do lençol freático, em geral, é adequada, considerando a CONAMA 396/2008. De forma geral, não foi possível identificar uma correlação evidente entre a qualidade da água do lençol freático e o uso e ocupação da terra na BEARJ. As análises de regressão múltipla indicam que o tipo de solo, a presença de agricultura e pastagem são as características que mais aparecem nas análises de influência sobre a qualidade da água nos poços, mas não representam necessariamente um problema.

PALAVRAS-CHAVE: Água subterrânea - Uso e ocupação da terra - Agricultura Cerrado - Regressão Quadrática Múltipla. 


\begin{abstract}
Araújo, Luane Souza de. Evaluation of groundwater quality (water table) and its correlation with land use and land cover in Upper Jardim Experimental River Basin (DF). 2016. 83p. Dissertation (MA) - Programa de Pós-Graduação em Geografia, Universidade de Brasília, Brasília, 2016.

The land use have been changing with time and modifying the natural spaces. Agricultural expansion is one of the agents of such changes. Given this, there is a need to assess their impacts, more specifically on water resources. Thus, the objective of this study was to evaluate the impacts of land use and land cover on the water quality of the groundwater (water table) in an agricultural area, in the Federal District. The water quality was analyzed in 38 piezometric wells distributed in the study area, the Upper Jardim Experimental River Basin, in the Federal District, Brazil. Samples were collected monthly from July 2014 to June 2015. The 15 analyzed variables were: electrical conductivity (EC), total dissolved solids (SDT), pH, alkalinity, bicarbonate, total hardness, soluble phosphorus (Ps); ions: chloride $\left(\mathrm{Cl}^{-}\right)$, fluoride $\left(\mathrm{F}^{-}\right)$, nitrate $\left(\mathrm{NO}_{3}{ }^{-}\right)$, sodium $\left(\mathrm{Na}^{+}\right)$, potassium $\left(\mathrm{K}^{+}\right)$, calcium $\left(\mathrm{Ca}^{2+}\right)$, magnesium $\left(\mathrm{Mg}^{2+}\right)$ and sulfate $\left(\mathrm{SO}_{4}{ }^{2-}\right)$. The definition of the drainage area of each well was carried out using the TauDEM tool. Land use and land cover were defined for each of these areas. Data were analyzed using: descriptive statistics; comparison of the measured values with the reference values of the CONAMA legislation $\mathrm{n}^{\mathrm{o}} 396 / 2008$ for Class 1 and 2; and multiple quadratic regression models, involving 16 independent variables. The results indicate that the groundwater quality (water table) is, in general, adequate considering CONAMA 396/2008. In general, it was not possible to identify an evident correlation between groundwater quality (water table) and land-use in the watershed. Multiple regression analyzes indicate that the type of soil, the presence of agriculture and pasture are the characteristics that most influence the water quality in the wells, but not representing a real problem.
\end{abstract}

KEY WORDS: Groundwater - Land use and Land Cover - Agriculture - Cerrado Biome - Multiple Quadratic Regression. 
1. INTRODUÇÃO......................................................................................... 14

2. REFERENCIAL TEÓRICO.......................................................................... 16

2.1. A ocupação do Cerrado ......................................................................... 16

2.2. Legislação Brasileira aplicada à água subterrânea ................................... 17

2.3. Conceituando água subterrânea ................................................................ 19

2.4. Água subterrânea e qualidade da água .................................................... 19

2.5.Parâmetros de qualidade da água............................................................ 22

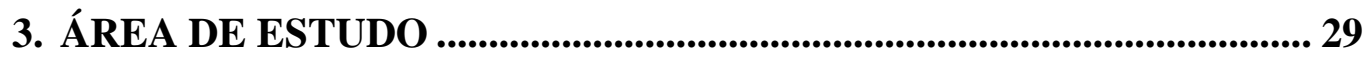

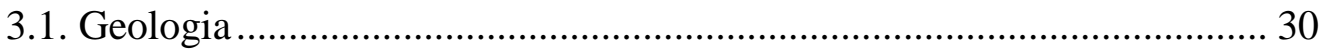

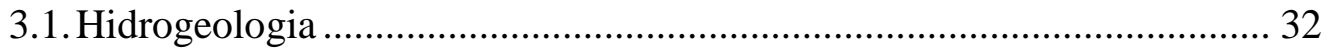

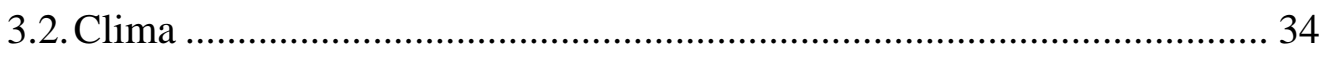

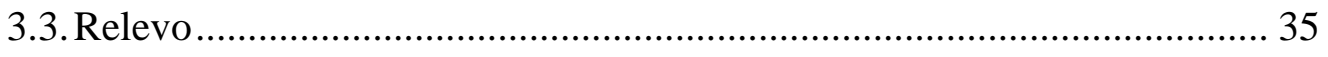

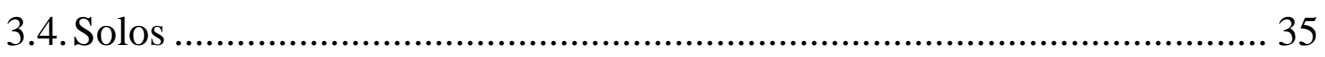

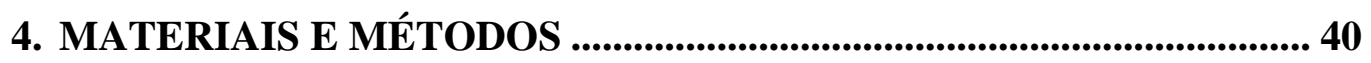

4.1.Levantamento dos Dados............................................................................ 40

4.2. Tratamento dos dados de qualidade da água ............................................. 47

4.3. Delimitação da área de drenagem............................................................ 48

4.4. Vetorização e classificação do uso e ocupação da terra ............................. 49

4.5. Análise estatística dos dados ....................................................................... 50

4.5.1. Estatística Descritiva ........................................................................ 50

4.5.2. Regressão Quadrática Múltipla ......................................................... 50

5. RESULTADOS E DISCUSSÃO.........................................................54

5.1. Mapas de Delimitação e Classificação ………………………………….... 54 
5.2. Análise da estatística descritiva: Valores Médios, Desvio-Padrão e

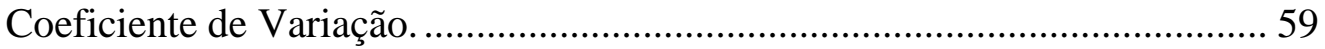

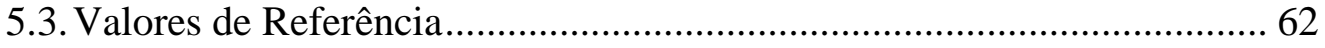

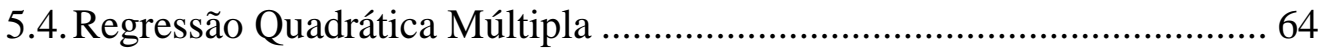

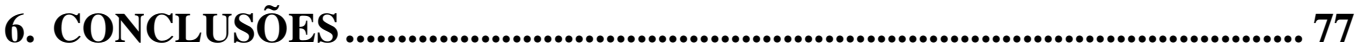

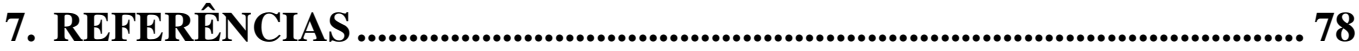




\section{LISTA DE FIGURAS}

Figura 1 - Localização da Bacia Experimental do Alto Rio Jardim/ DF.

Figura 2 - Geologia da Bacia Experimental do Alto Rio Jardim (adaptado de Freitas-Silva \& Campos, 1998).

Figura 3 - Declividade da Bacia Experimental do Alto Rio Jardim. 35

Figura 4 - Classe dos solos da Bacia Experimental do Alto Rio Jardim (adaptado de Reatto et al., 2000). 36

Figura 5 - Textura dos solos da Bacia Experimental do Alto Rio Jardim (adaptado de Reatto et al., 2000).

Figura 6 - Limite da BEARJ com pontos dos poços alocados. 40

Figura 7 - a) Amostrador de PVC (tipo bailer), b) coleta e c) amostras nos frascos de polietileno.

Figura 8 - Sonda multiparâmetros Sension 156, marca HACH.

Figura 9 - Titulador automático 876 dosimat plus/dosímetro, marca METROHM.44

Figura 10 - Filtragem das amostras. 44

Figura 11 - Espectrofotômetro modelo UV-1800, marca SHIMADZU 45

Figura 12 - Cromatógrafo Iônico modelo 761 Compact IC, marca METHROHM. 46

Figura 13 - Mapa das áreas de drenagem da Bacia Experimental do Alto Rio Jardim. 54

Figura 14 - Mapa de uso e ocupação da terra da Bacia Experimental do Alto Rio Jardim. 55

Figura 15 - Mapa de uso e ocupação da terra das áreas de drenagem inseridas na Bacia Experimental do Alto Rio Jardim. 57 
Figura 16 - Mapa da classe do solo das áreas de drenagem inseridas na Bacia Experimental do Alto Rio Jardim.............................................................................. 58

Figura 17 - Coeficiente de Variação das variáveis analisadas durante um ano hidrológico...... 61 


\section{LISTA DE TABELAS}

Tabela 1 - Parâmetros monitorados e seus respectivos métodos de análise.

Tabela 2 - Área em hectare (ha) das classes de uso e ocupação da terra na Bacia Experimental do Alto Rio Jardim. 56

Tabela 3 - Área em hectare (ha) das classes de uso e ocupação da terra das áreas de drenagem da Bacia Experimental do Alto Rio Jardim. 57

Tabela 4 - Área em hectare (ha) das classes de solo das áreas de drenagem da Bacia Experimental do Alto Rio Jardim. 58

Tabela 5 - Média, Desvio-Padrão e Coeficientes de Variação para CE, SDT, pH e P.

Tabela 6 - Média, Desvio-Padrão e Coeficientes de Variação para ALC, BIC, DUR e $\mathrm{Na}^{+}$. 60

Tabela 7 - Média, Desvio-Padrão e Coeficientes de Variação para $\mathrm{K}^{+}, \mathrm{Ca}^{2+}, \mathrm{Mg}^{2+} \mathrm{e}$ $\mathrm{F}^{-}$. 60

Tabela 8 - Média, Desvio-Padrão e Coeficientes de Variação para $\mathrm{Cl}^{-}, \mathrm{NO}_{3}{ }^{-}$e $\mathrm{SO}_{4}{ }^{2-}$.

Tabela 9 - Valores Máximos Permitidos de acordo com a resolução CONAMA n ${ }^{\circ}$ 396/08

Tabela 10 - Coeficientes estimados e padronizados relativos ao teste t, no intervalo de confiança de $95 \%$ para os coeficientes da regressão quadrática múltipla para a variável fósforo e sua relação com uso da terra, solo, área de contribuição, nível e declividade dos poços da BEARJ para o mês de julho de 2014. 65

Tabela 11 - Coeficientes $\beta$ padronizados relativos às variáveis independentes dos modelos da regressão quadrática múltipla que conferiram maior contribuição para a variável fósforo em determinado mês. 66 
Tabela 12 - Coeficientes $\beta$ padronizados relativos às variáveis independentes dos modelos da regressão quadrática múltipla que conferiram maior contribuição para as variáveis condutividade elétrica e sólidos dissolvidos totais em determinado mês. 67

Tabela 13 - Coeficientes $\beta$ padronizados relativos às variáveis independentes dos modelos da regressão quadrática múltipla que conferiram maior contribuição para a variável pH em determinado mês.

Tabela 14 - Coeficientes $\beta$ padronizados relativos às variáveis independentes dos máveis alcalinidade e bicarbonato em determinado mês.

Tabela 15 - Coeficientes $\beta$ padronizados relativos às variáveis independentes dos modelos da regressão quadrática múltipla que conferiram maior contribuição para a variável dureza em determinado mês. 70

Tabela 16 - Coeficientes $\beta$ padronizados relativos às variáveis independentes dos modelos da regressão quadrática múltipla que conferiram maior contribuição para a variável sódio em determinado mês. 70

Tabela 17 - Coeficientes $\beta$ padronizados relativos às variáveis independentes dos mriável cálcio em determinado mês.

Tabela 18 - Coeficientes $\beta$ padronizados relativos às variáveis independentes dos modelos da regressão quadrática múltipla que conferiram maior contribuição para a variável magnésio em mês.

Tabela 19 - Coeficientes $\beta$ padronizados relativos às variáveis independentes dos modelos da regressão quadrática múltipla que conferiram maior contribuição para a variável cloreto em determinado mês. 72

Tabela 20 - Coeficientes $\beta$ padronizados relativos às variáveis independentes dos modelos da regressão quadrática múltipla que conferiram maior contribuição para a variável potássio em determinado mês. 73 
Tabela 21 - Coeficientes $\beta$ padronizados relativos às variáveis independentes dos modelos da regressão quadrática múltipla que conferiram maior contribuição para a variável fluoreto em determinado mês.

Tabela 22 - Coeficientes $\beta$ padronizados relativos às variáveis independentes dos modelos da regressão quadrática múltipla que conferiram maior contribuição para a variável nitrato em determinado mês.

Tabela 23 - Coeficientes $\beta$ padronizados relativos às variáveis independentes dos modelos da regressão quadrática múltipla que conferiram maior contribuição para a variável sulfato em determinado mês. 75 


\section{LISTA DE SIGLAS E ABREVIATURAS}

\begin{tabular}{|c|c|}
\hline APHA & American Public Health Association \\
\hline BEARJ & Bacia Experimental do Alto Rio Jardim \\
\hline $\mathbf{B r}^{-}$ & Brometo \\
\hline $\mathrm{Ca}^{+2}$ & Cálcio \\
\hline $\mathrm{CaCO}_{3}$ & Carbonato de cálcio \\
\hline CETESB & Companhia de Tecnologia de Saneamento Ambiental do Estado de São Paulo \\
\hline $\mathrm{Cl}^{-}$ & Cloreto \\
\hline CNRH & Conselho Nacional de Recursos Hídricos \\
\hline $\mathrm{CO}_{2}$ & Dióxido de Carbônico \\
\hline CONAMA & Conselho Nacional do Meio Ambiente \\
\hline $\mathbf{C E}$ & Condutividade Elétrica \\
\hline CSR & Carbonato de Sódio Residual \\
\hline $\mathbf{C V}$ & Coeficiente de Variação \\
\hline DP & Desvio Padrão \\
\hline DF & Distrito Federal \\
\hline DUR & Dureza Total \\
\hline $\mathbf{d S} \mathbf{m}^{-}$ & DeciSiemens por metro \\
\hline EMBRAPA & Empresa Brasileira de Pesquisa Agropecuária \\
\hline $\mathbf{F}^{-}$ & Fluoreto \\
\hline $\mathbf{H}^{+}$ & Íons Hidrogênio \\
\hline HA & Hectares \\
\hline $\mathrm{HCO}_{3}^{-}$ & Bicarbonato \\
\hline $\mathrm{H}_{2} \mathrm{SO}_{4}$ & Ácido Sulfúrico \\
\hline IBGE & Instituto Brasileiro de Geografia e Estatística \\
\hline $\mathbf{K}^{+}$ & Potássio \\
\hline $\mathbf{K M}$ & Quilômetro \\
\hline $\mathbf{K} \mathbf{M}^{2}$ & Quilômetro quadrado \\
\hline LD & Limite de Detecção \\
\hline $\mathbf{L i}^{+}$ & Lítio \\
\hline LQP & Limite de Quantificação Praticável \\
\hline
\end{tabular}




\begin{tabular}{|c|c|}
\hline MÁX & Máximo \\
\hline MDE & Modelo Digital de Elevação \\
\hline MDT & Modelo Digital de Terreno \\
\hline Mín & Mínimo \\
\hline $\mathrm{Mg}^{2+}$ & Magnésio \\
\hline $\mathrm{Mg} / \mathrm{L}^{-1}$ & Miligrama por litro \\
\hline $\mathbf{N a}^{+}$ & Sódio \\
\hline $\mathbf{N H}_{3}$ & Amoníaco \\
\hline $\mathbf{N H}_{4}^{+}$ & Amônio \\
\hline $\mathrm{NO}_{2}^{-}$ & Nitrito \\
\hline $\mathrm{NO}_{3}^{-}$ & Nitrato \\
\hline $\mathbf{P}$ & Fósforo \\
\hline PGIRH & Plano de Gerenciamento Integrado de Recursos Hídricos \\
\hline PIB & Produto Interno Bruto \\
\hline PNRH & Política Nacional de Recursos Hídricos \\
\hline $\mathrm{PO}_{4}{ }^{3^{-}}$ & Fosfato \\
\hline Ps & Fósforo Solúvel \\
\hline PVC & Policloreto de Vinila \\
\hline RAS & Relação de Adsorção de Sódio \\
\hline SDT & Sólidos Dissolvidos Totais \\
\hline SICAD/DF & Sistema Cartográfico do Distrito Federal \\
\hline SINGREH & Sistema Nacional de Gerenciamento de Recursos Hídricos \\
\hline SMEWW & Standard Methods for the Examination of Water and Wastewater \\
\hline $\mathrm{SO}_{4}^{-2}$ & Sulfato \\
\hline TauDEM & Terrain Analysis Using Digital Elevation Models \\
\hline$\mu g . \mathrm{L}_{-}{ }^{1}$ & Micrograma por Litro \\
\hline uS/cm & Microsiemens por centímetro \\
\hline VMP & Valores Máximos Permitidos \\
\hline $\mathbf{V}$ & Volume \\
\hline
\end{tabular}




\section{INTRODUÇÃO}

O esforço de desenvolvimento brasileiro conferiu à agricultura papel de extrema importância, especialmente tendo-se em conta a tarefa de alimentar a população, fornecer matéria-prima às indústrias de transformação e gerar divisas, pela exportação de produtos básicos (EMBRAPA, 1977).

O II Plano Nacional de Desenvolvimento estabeleceu metas de modernização da agricultura tradicional e, também, a incorporação de novas áreas. A ocupação dos Cerrados revelou-se, assim, como alternativa (EMBRAPA, 1976).

As condições amplamente conhecidas, em termos de mercado, de estoques e de demanda por alimentos, fizeram do Brasil um ponto de convergência capaz de contribuir decisivamente para atender as carências existentes. Nesse contexto, o Cerrado brasileiro passa a assumir particular importância, uma vez que integrados ao processo produtivo, mediante sistemas exploratórios ajustados às peculiaridades, vem fortalecendo a participação econômica atribuída à agricultura (QUEIROZ, 2003).

Desde o processo de ocupação, toda a região se transformou bruscamente, e de forma incisiva no que diz respeito à utilização dos recursos naturais. $\mathrm{O}$ uso e ocupação da terra com lavouras tecnificadas, voltadas à produção de soja e milho para exportação exemplifica como se deu a modernização da agricultura (FRANCO, 2001).

A expansão agrícola induzida pelo desenvolvimento econômico produziram mudanças nos padrões de uso e ocupação da terra, como por exemplo, a retirada de cobertura vegetal natural, para o uso agrícola. Assim sendo, o impacto dessas modificações pode gerar uma série de consequências no ciclo hidrológico da bacia (TUCCI, 1997).

A ocupação do Cerrado se deu de forma acelerada e muitas vezes, desordenada, ocorrendo assim conflitos em torno do uso da terra e da água gerando problemas no que se refere aos recursos hídricos (PGIRH, 2012).

Essas influências alteram a quantidade, a distribuição e a qualidade dos recursos hídricos, e como o ser humano é totalmente dependente deste recurso natural, sua alteração pode ameaçar sua sobrevivência e de todas as formas de vida na Terra. Assim, 
tanto o desenvolvimento econômico, como o social do país está interligado à disponibilidade, qualidade, conservação e proteção da água (TUNDISI, 1999).

Outro fato importante é o papel que os recursos hídricos desempenham, pois, agem como integradores dos processos biogeoquímicos de qualquer área ou região. Nesse sentido, quando água e fertilizantes em excesso são aplicados, particularmente na agricultura, os recursos hídricos, sejam superficiais ou subterrâneos, são os principais destinos a serem atingidos (VASCONCELOS et al., 2014).

Por isso, a preocupação com a qualidade da água tem sido objeto de pesquisa nos últimos anos, e a sua classificação de fundamental importância, uma vez que fornece subsídios para a avaliação da sua utilização em relação ao sistema água-solo-planta e ao regime de irrigação (VASCONCELOS et al., 2014).

Mais especificadamente em regiões rurais, o problema da contaminação da água por meio dos agrotóxicos, fertilizantes, esgotos domésticos e excrementos animais tem ganhado relevância devido à possibilidade de infiltração destes contaminantes nos aquíferos ou diretamente nos poços, necessitando assim, do devido controle dos mesmos (MELIAN et al., 1999).

De acordo com Foster et al. (2006) é importante conhecer a pedologia e a geologia do local do empreendimento potencialmente poluidor, observando dentro outros aspectos, a capacidade de infiltração, proporcionada pelos materiais que compõem o solo. Quanto maior a capacidade de a água infiltrar maior será o perigo de contaminação das águas subterrâneas.

Diante do exposto, verifica-se a necessidade do monitoramento dos recursos hídricos, pois informações sobre a quantificação dos poluentes auxiliarão na devida gestão dos recursos hídricos subterrâneos.

Deste modo, foi avaliada a qualidade da água do lençol freático e sua correlação com o uso e ocupação da terra em área agrícola do Cerrado no DF. Sendo o objetivo específico:

- Identificar as características naturais e antrópicas que mais influenciam na qualidade da água do lençol freático nos poços analisados. 


\section{REFERENCIAL TEÓRICO}

\subsection{A ocupação do Cerrado}

A ocupação do Centro-Oeste brasileiro aconteceu devido ao esgotamento das terras de cultivo situadas em torno das matas das regiões Sul e Sudoeste. As opções encontradas pelos agropecuaristas foram então as reservas florestais das bacias do Paraná-Paraguai, do Tocantins-Araguaia e, sobretudo, da pré-Amazônia mato-grossense (EMBRAPA, 1978)

Nos anos 40, registrou-se uma grande revolução no setor, com a instalação de duas grandes colônias agrícolas pelo Governo Federal: a Colônia Agrícola Nacional de Goiás (Mato Grosso de Goiás) e a Colônia Agrícola de Dourados (Mato Grosso), o que provocou a expansão da atividade agrícola na região, até então restrita a pecuaristas e extrativistas (EMBRAPA, 1978).

Na década de 50, a imigração foi fomentada pela descoberta e exploração de áreas diamantíferas e de cristal de rocha e pelo ciclo do café, na região de Mato Grosso de Goiás, tendo início a era agrícola. Em seguida, com a implantação de Brasília, surge a necessidade de um sistema viário para atender as demandas da Capital Federal, facilitando o deslocamento de correntes migratórias do Norte e Nordeste (EMBRAPA, 1978).

Visando a fixação desse contingente populacional deslocado e melhores condições para o desenvolvimento agropecuário, na década de 70 o Governo Federal criou incentivo, tal como o Programa de Desenvolvimento dos Cerrados - POLOCENTRO, com o objetivo de promover e executar a política de ocupação técnica e humana dos Cerrados (EMBRAPA, 1978).

O crédito rural subsidiado disponibilizado através do POLOCENTRO propiciou a introdução de tecnologias modernas que incorporaram o cerrado à produção agrícola moderna, beneficiando assim os grandes e médios produtores a partir da década de 1970 e também, alterando a base produtiva no que diz respeito à concentração de terras em grandes propriedades e à produção de monoculturas voltadas para a exportação e intensiva (FARIA et al., 2009). 
O Centro-Oeste veio apresentando grande representatividade no setor agropecuário, entretanto nas décadas seguintes houve uma diminuição, e outros setores ganharam expressão, como a indústria que contava com 6,5\% do produto regional, em 1960 e em 1996 atingiu 17,1\%; e o setor de serviços que obteve um alto crescimento, que em 1960 representava $41 \%$ e em 1996 atingiu 68,8\% do produto total da região (NETO e GOMES, 2000).

Além do crescimento do produto regional dos novos setores, houve um expressivo crescimento populacional na região. Em 1950, a densidade demográfica do CentroOeste era da ordem de 1,1 habitantes por quilômetro quadrado, atingindo uma média de 3,1 habitantes por quilômetro quadrado em 1970, 5,8 em 1991 e 7,23 em 2000 (IBGE, 2003).

Outro dado importante, que diz respeito aos censos agropecuários, apresentados por Rezende (2002) refere se à área ocupada pela agricultura. Em 1980, 60\% da área geográfica do Centro-Oeste eram ocupadas por estabelecimentos agrícolas, contra apenas 11,6\% na região Norte e 56,7\% no Nordeste. No ano de 1996, a percentagem subiu para $66 \%$, enquanto na região Norte se manteve constante. Este fato favoreceu a incorporação de inovação tecnologia mais recente.

Desta forma, as transformações no espaço natural se deram pela forte mecanização na região, estando intrinsecamente relacionadas pelo aumento de produtividade do Cerrado nas décadas de 70, 80 e 90 e, pequenas manchas do Cerrado original restaram (LIMA, 1996).

\subsection{Legislação Brasileira aplicada à água subterrânea}

A Legislação Brasileira sobre recursos hídricos destaca-se no Código das Águas de 1934, assumindo o papel de marco legal do gerenciamento dos recursos hídricos no Brasil (SENRA et al., 2004).

Na década de 80 a água era vista como bem imóvel, ou seja, referente à propriedade e era utilizada para suprir necessidades básicas, como o uso doméstico. Porém, com a demanda crescente e usos múltiplos da água a necessidade de reformulações na legislação ocasionou alterações a partir da Constituição Federal de 1988 no Código de 
34. Tais modificações resultaram na publicização das águas, ou seja, bem público, e a água subterrânea passa a ser gerida pelos Estados e Distrito Federal (PONTES et al., 2007).

Posteriormente, houve a criação de órgãos cada vez mais especializados no tocante ao meio ambiente e recursos hídricos e em 1997 foi editada a Lei 9433 que instituiu a Política Nacional de Recursos Hídricos - PNRH e criou o Sistema Nacional de Gerenciamento de Recursos Hídricos - SINGREH (BRASIL, 1997).

$\mathrm{O}$ arcabouço legal brasileiro foi baseado nas águas superficiais, entretanto, a partir do Projeto Aquífero Guarani (1999) a discussão sobre a necessidade de normatizações orientativas gerais, de abrangência nacional, para as questões das águas subterrâneas se evidenciaram (HAGER; D'ALMEIDA, 2008).

Em 2000 criou-se da Câmara Técnica Permanente de águas subterrâneas no Conselho Nacional de Recursos Hídricos - CNRH e a resolução CNRH nº 15, em 2001, que estabelece diretrizes para a gestão de águas subterrâneas, estes fatos auxiliaram na inserção da água subterrânea nas discussões, aprimorando assim, sua normatização (HAGER; D’ALMEIDA, 2008).

Somente após oito anos da criação da Câmara Técnica publicaram a resolução CONAMA n ${ }^{\circ} 396$, de 3 de abril de 2008, que dispõe sobre a classificação e diretrizes ambientais para o enquadramento, prevenção e controle da poluição das águas subterrâneas (CONAMA, 2008).

Por meio desta legislação as águas subterrâneas são classificadas em classe especial, $1,2,3,4$ e 5, cada uma com suas especificidades, também se refere às condições e padrões destas águas, as diretrizes para prevenção e controle da poluição, além do que diz respeito ao enquadramento (CONAMA, 2008).

A resolução apresenta em seu anexo I uma lista de parâmetros com os valores máximos permitidos (VMP) para cada um dos usos considerados como principais e os limites de quantificação praticáveis (LQP) (CONAMA, 2008).

Em seu segundo anexo, é exposto o exemplo de estabelecimento de padrões por classe para parâmetros selecionados de acordo com o art. 12 ("Os parâmetros deverão ser escolhidos em função dos usos preponderantes, das características hidrogeologias, 
hidrogeoquímicas, das fontes de poluição e outros critérios técnicos. Parágrafo único. Dentre os parâmetros selecionados, deverão ser considerados, no mínimo, sólidos totais dissolvidos, nitrato e coliformes termotolerantes"), considerando o uso concomitante para consumo humano, dessedentação, irrigação e recreação (CONAMA, 2008).

\subsection{Conceituando água subterrânea}

Cederstrom (1964) pondera que o estudo da água subterrânea é uma ciência dinâmica, e esta água é comparada a compostos químicos em equilíbrio e, quando o mesmo é perturbado, tenta ajustar-se; e tendo reabastecimento, o equilíbrio tende a reverter-se em "equação" original.

A hidrologia de águas subterrâneas pode ser definida como a ciência do evento, distribuição e circulação da água abaixo da superfície da terra (TODD, 1959).

Água subterrânea se infiltra nos solos e nas rochas, percolando até o nível hidrostático (GUERRA e GUERRA, 1997). De acordo com Foster et al. (2006) a água subterrânea é um recurso natural essencial para o abastecimento econômico e seguro nos meios tanto urbano, quanto rural.

Feitosa e Manuel Filho (1997) expuseram um dado de suma importância; aproximadamente $97 \%$ da água doce disponível na Terra encontram-se no subsolo e, $3 \%$ da água potável disponível no planeta provêm das águas de superfície.

\section{4. Água subterrânea e qualidade da água}

A água subterrânea origina-se, em sua maior parte, pela chuva que se infiltra pela superfície do solo. Porém, as atividades desenvolvidas nesta superfície podem ameaçar a qualidade das mesmas, pois a carga de contaminantes gerada não possui o devido controle, além de estes excederem a capacidade de atenuação natural dos solos. (FOSTER et al., 2006).

Existem também, os componentes de vulnerabilidade natural de um aquífero, que não são diretamente mensuráveis e, sim, determinados por meio de combinações de outros fatores, entre eles. Além disso, dados referentes a vários fatores não podem ser 
facilmente estimados ou não estão disponíveis, o que obriga na prática a uma redução e simplificação da lista de parâmetros requeridos. Assim, a lista de parâmetros (vulnerabilidade ambiental) disponíveis fica reduzida a três: a) o tipo de ocorrência da água subterrânea; b) as características dos estratos acima de zona saturada, em termos de grau de consolidação e tipo litológico; c) a profundidade do nível da água (FOSTER e HIRATA, 1988).

Helena et al. (2000) complementaram a respeito da vulnerabilidade que o aquífero está exposto, mostrando que a qualidade das águas subterrâneas não depende apenas de fatores naturais como litologia do aquífero, a velocidade da água subterrânea, a qualidade das águas de recarga e interação com outros tipos de água ou aquíferos, mas também a interferência das atividades humanas, o que pode alterar estes sistemas frágeis, seja por poluí-los ou modificando o ciclo hidrológico, a tal medida que o uso de águas subterrâneas se torna restrito.

Em todo o mundo, os aquíferos estão sob perigo de contaminação (FOSTER et al., 2006). Isto se deve aos aumentos populacionais e consequente aumento da urbanização, intensificação da agricultura com uso de produtos tóxicos, entre outras atividades poluidoras.

Exemplo deste fato são os estudos que ocorrem em diversas cidades dos Estados Unidos das Américas - EUA. Kolpin et al. (1996) expõem que a contaminação de origem difusa dos recursos hídricos a partir de pesticidas na agricultura aplicada nos Estados Unidos é um tema importante e de crescente preocupação ambiental.

Kolpin et al.,(1998) estudaram 20 grandes bacias dos EUA com o objetivo de fazerem um resumo a cerca das concentrações e frequências dos compostos de pesticidas nas águas subterrâneas, além de observar se a variação do uso da terra está influenciando a qualidades da água. Os resultados mostraram que foram encontrados 39 compostos diferentes em $54,4 \%$ dos poços e raramente excederam critérios de água potável, estabelecidos pela U.S. Environmental Protection Agency - EPA para a proteção da saúde humana.

No norte da Espanha um trabalho semelhante foi desenvolvido, com o intuito de desenvolver um programa de monitoramento para examinar se o uso recomendado de pesticidas pode produzir impacto sobre a qualidade de águas superficiais e subterrâneas. 
Os resultados apresentados por Hildebrandt et al. (2008) expuseram que em águas superficiais os pesticidas são rapidamente fotodegradados, já os mesmos podem ficar longos períodos nas águas subterrâneas. E que o total de $88 \%$ das medições tinham níveis mais baixos do que a $0,1 \mathrm{mg} / \mathrm{L}$, de acordo com o limite fixado pela União Europeia, indicando uma contaminação difusa de baixo nível.

No Brasil, os mais diversos estudos também são realizados no que se refere à qualidade das águas subterrâneas. Júnior et al. (2006) estudaram as características qualitativas das águas subterrâneas; avaliaram seu uso para irrigação e determinaram a porcentagem de poços onde o uso da água para irrigação é prioritário no Piauí e classificaram em 3 classes de restrição de uso: nenhuma, moderada e severa restrição.

As variáveis utilizadas foram condutividade elétrica, $\mathrm{pH}$, sódio, cálcio, magnésio, cloreto, carbonato, bicarbonato, sulfato, carbonato de sódio residual (CSR) e relação de adsorção de sódio (RAS). Os resultados encontrados mostraram que, a geologia tem forte interferência sobre a qualidade da água e que ocorre progressiva redução da salinidade no interior da bacia. Parâmetros como cálcio e magnésio mostraram-se elevados, mas dentro dos limites, e bicarbonato e cloreto apresentaram moderada restrição de uso.

No Estado do Rio Grande do Norte, Vasconcelos et al. (2013) avaliaram os níveis de qualidade de água subterrâneas de uma propriedade agrícola produtora de melão em Mossoró. O aquífero Jandaíra possui elevada salinidade e alta vulnerabilidade à contaminação, devido às propriedades geológicas, pois está inserido no domínio hidrogeológico intersticial e karstico-fissural, ou seja, há fissuras nas rochas facilitando, assim, a entrada de poluentes.

Foram analisados 13 poços tubulares de janeiro a outubro de 2012, totalizando 91 amostras e analisados parâmetros de condutividade elétrica, $\mathrm{pH}$ e nitrato. Utilizou-se estatística descritiva para a análise e concluíram que a salinidade, a condutividade elétrica e o nitrato possuem restrição de ligeira à moderada; enquanto o pH apresentou variações aceitáveis.

Em muitos locais a água subterrânea é a única fonte de captação para a realização das mais diversas funções, como o abastecimento humano, irrigação, lazer, piscicultura, 
entre outros, por isso a necessidade do monitoramento dos recursos hídricos dessas zonas.

Parron et al. (2009) realizam um estudo onde avaliaram o uso de parâmetros de qualidade da água de poços piezométricos como indicadores ambientais de mudança no uso do solo na BEARJ concluindo que a química da água subterrânea pode ser utilizada como indicador ambiental de mudanças no uso do solo.

Outro dado conclusivo desta pesquisa foi que a análise estatística mostrou que as características físico-químicas da água são distintas de acordo com o uso ou não da terra, assim, parâmetros como a condutividade elétrica, $\mathrm{pH}$ e as concentrações de $\mathrm{Na}^{+}$, $\mathrm{Ca}^{+2}, \mathrm{Mg}^{+2}, \mathrm{HCO}_{3}^{-}$e $\mathrm{NO}_{3}^{-}$foram maiores nos poços subterrâneos em áreas de horticultura, em relação a áreas conservadas de Cerrado.

Araújo (2006) realizou a análise geoquímica das águas subterrâneas freáticas da bacia do Alto Jardim, a fim de obter informações sobre agrotóxicos e corretivos utilizados na região, além de identificar locais com maior risco de contaminação nos aquíferos.

A pesquisa concluiu que poços com profundidades menores que 5 metros são mais vulneráveis à contaminação; a sazonalidade influência o potencial de contaminação dos aquíferos; o uso do solo torna-se um parâmetro para afirmar sobre o risco de contaminação de determinado aquífero; e o principal indicador de contaminação das águas freáticas é o nitrato, atingindo até $21 \mathrm{mg} . \mathrm{L}^{-1}$.

Deste modo, destaca-se a necessidade do monitoramento deste recurso, pois informações sobre a quantificação dos poluentes auxiliarão na devida gestão dos recursos hídricos subterrâneos.

\subsection{Parâmetros de qualidade da água}

Nos próximos tópicos será apresentada uma breve descrição conceitual dos parâmetros analisados neste estudo.

\section{- Condutividade Elétrica - CE}

A condutividade elétrica da água mede a capacidade deste parâmetro conduzir corrente elétrica, sendo proporcional à concentração de íons dissociados em um sistema 
aquoso. Entretanto, não distingue quais são os íons presentes em água, mas é um indicador importante de possíveis fontes poluidoras (ZUIN et al, 2009).

"A condutividade também fornece uma boa indicação das modificações na composição de uma água, especialmente na sua concentração mineral, mas não fornece nenhuma indicação das quantidades relativas dos componentes" (MORAES, 2008).

\section{- Sólidos Dissolvidos Totais - SDT}

"É o peso total dos constituintes minerais presentes na água, por unidade de volume, representando a concentração de todo o material dissolvido na água, seja ou não volátil” (FEITOSA; MANOEL FILHO, 2000).

Usualmente os sólidos dissolvidos totais são um pouco superior do que o resíduo seco, em função do $\mathrm{HCO}_{3}$ (bicarbonato), que em altas temperaturas $\left(>100^{\circ} \mathrm{C}\right.$ ) se decompõe em parte como $\mathrm{CO}_{3}^{-2}$ e em parte como $\mathrm{CO}_{2}$, que se volatiza e evapora da amostra (FEITOSA; MANOEL FILHO, 2000).

A resolução CONAMA no 396, em seu anexo I, apresenta os Valores Máximos Permitidos (VMP) para cada um dos usos considerados como preponderantes e os limites de quantificação praticáveis (LQP). No que diz respeito ao SDT, a legislação se refere como VMP para consumo humano $1.000 .000 \mu \mathrm{g} . \mathrm{L}^{-1}$ e seu LQP são $2000 \mu \mathrm{g} . \mathrm{L}^{-1}$ (CONAMA, 2008).

\section{- Salinidade}

"Refere-se à salinidade com relação à quantidade total de sólidos dissolvidos, expressa em miligramas por litro, partes por milhão ou por meio de sua condutividade elétrica" (BERNARDO; SOARES; MANTOVANI, 2006).

O teor de sais em águas subterrâneas depende de sua origem, do curso sobre o qual ela flui e da composição e facilidade de dissolução do substrato em que se encontra em contato (YARON, 1973), ou seja, da geologia da região (SHALHEVET e KAMBUROV, 1976). 


\section{- Potencial Hidrogeniônico - pH}

$\mathrm{O}$ pH "representa a concentração de íons hidrogênio $\mathrm{H}+$, dando um indicação sobre a condição de acidez, neutralidade ou alcalinidade da água. A faixa de pH é de 0 a 14”, onde 0 representa um meio ácido e 14 meio básico. (VON SPERLING, 2005).

As origens antrópicas são efluentes domésticos e industriais e as naturais são decorrentes de rochas, gases da atmosfera e fotossíntese. Assim, tantos valores muitos baixos ou elevados exercem influência negativa no meio (VON SPERLING, 2005).

De acordo com a resolução CONAMA n ${ }^{\circ} 357$, as águas doces de classe 1 possuem como padrão valor de pH entre 6,0 e 9,0 (CONAMA, 2005).

\section{- Fósforo}

Von Sperling (2005) apresenta as formas deste parâmetro como ortofosfato, polifosfato e fósforo orgânico. O fósforo é um importante nutriente para os processos biológicos que ocorrem nos corpos d'água.

Entre as origens de fósforo nas águas estão os esgotos domésticos (detergentes superfosfatados e da matéria fecal), fertilizantes, efluentes industriais, entre outras. $\mathrm{O}$ escoamento pluvial tanto de áreas agrícolas quanto de áreas urbanas é fonte significativa de fósforo para os corpos d'água (VON SPERLING, 2005).

\section{- Alcalinidade}

A alcalinidade indica a quantidade de íons na água que reagem para neutralizar os íons hidrogênio. Constitui-se, portanto, em uma medição da capacidade da água de neutralizar os ácidos, servindo assim para expressar a capacidade de tamponamento da água, sua condição de resistir a mudança do $\mathrm{pH}$. Sua origem natural provém de rochas e matéria orgânica; e sua origem antropogênica é referente aos despejos domésticos e industriais (MORAES, 2008).

A capacidade de neutralização deste parâmetro está diretamente relacionada com a presença e/ou ausência de carbonatos e bicarbonatos na água (FEITOSA; MANOEL FILHO, 2000). 


\section{- Bicarbonato $\left(\mathrm{HCO}_{3}{ }^{-}\right)$}

"Este íon não se oxida nem se reduz em águas naturais, porém pode se precipitar com muita facilidade como bicarbonato de cálcio $\left(\mathrm{CaCO}_{3}\right)$. É benéfico aos vegetais, principalmente na forma de bicarbonato de cálcio" (FEITOSA; MANOEL FILHO, 2000).

Segundo Bernardo et al. (2006) concentrações elevadas de íons de bicarbonato nas águas levam a precipitação do cálcio e do magnésio, sob a forma de carbonatos, ocasionando a redução da concentração dos mesmos na solução do solo e, aumentando a proporção de sódio.

\section{- Dureza Total}

“Concentração de cátions mutimetálicos em solução. Os cátions mais

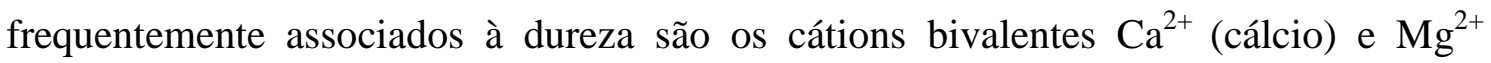
(magnésio). Em condições de superfaturação, esses cátions reagem com ânions na água, formando precipitados" (VON SPERLING, 2005).

De acordo com Custódio e Llamas (1983) os padrões da dureza da água são: branda, com concentração de até $50 \mathrm{mg} / \mathrm{L}^{-1} \mathrm{CaCO}_{3}$; pouco dura entre 50 e $100 \mathrm{mg} / \mathrm{L}^{-1}$; dura, entre 100 e $200 \mathrm{mg} / \mathrm{L}^{-1}$; e muito dura, acima de $200 \mathrm{mg} / \mathrm{L}^{-1}$.

\section{- Íons}

Os átomos podem ganhar ou perder elétrons, ou seja, deixam de ser eletricamente neutros e passam a ser dotados de carga elétrica, transformando-se em íon. Desta forma, um íon positivo recebe o nome de cátion e o íon negativo é o ânion (TITO \& CANTO, 2002). Muitas das substâncias dissolvidas presentes nas águas subterrâneas encontra-se no estado iônico, sendo que sua soma representa a quase totalidade dos íons presentes nessas águas (FEITOSA; MANOEL FILHO, 2000).

\section{$\underline{\text { Cátions }}$}

- Lítio $\left(\mathrm{Li}^{+}\right)$

O lítio não é bioacumulativo e sua ingestão em alimentos e água, sua exposição ocupacional, não apresentam riscos, devido sua toxicidade ser baixa, além de não apresentar ameaça a flora e fauna aquática. Este elemento químico é encontrado em águas subterrâneas a uma concentração de até $500 \mu \mathrm{g} . \mathrm{L}_{-}{ }^{1} \mathrm{Li}$ (ARAL; VECCHIO, 2008). 
A legislação brasileira, resolução CONAMA no 357 , determina como $2,5 \mathrm{mg} / \mathrm{L}^{-1} \mathrm{o}$ valor padrão para águas doces de classe 1 (CONAMA, 2008).

- Sódio $\left(\mathrm{Na}^{+}\right)$

É um dos metais alcalinos mais importantes e abundantes nas águas subterrâneas, predominando em algumas, devido a características como: distribuição ampla dos minerais fontes; baixa estabilidade química dos minerais que o contém; solubilidade elevada e difícil precipitação da maioria dos seus compostos químicos em solução (FEITOSA; MANOEL FILHO, 2000).

É o principal responsável pelo aumento constante da salinidade das águas naturais do ponto de vista catiônico e sua concentração varia nas águas subterrâneas, em geral, entre 0 e $100 \mathrm{mg} / \mathrm{L}^{-1}$. (FEITOSA; MANOEL FILHO, 2000). A resolução CONAMA n ${ }^{\circ}$ 396/2008 para águas subterrâneas estabelece como VMP $200 \mathrm{mg} / \mathrm{L}^{-1}$ para o uso consumo humano (CONAMA, 2008).

\section{- Potássio $\left(\mathrm{K}^{+}\right)$}

Ocorre em pequenas quantidades ou está ausente nas águas subterrâneas, devido à participação intensa em processos de troca iônica, além da facilidade de se adsorvido pelos minerais de argila e, ainda, de seus sais serem bastante utilizados pelos vegetais em seu desenvolvimento, sendo muito utilizado no solo como fertilizante. Assim, seu teor nestas águas são inferiores a $10 \mathrm{mg} / \mathrm{L}^{-1}$, sendo mais frequente valores entre 1 e 5 $\mathrm{mg} / \mathrm{L}^{-1}$ (FEITOSA; MANOEL FILHO, 2000).

\section{- Amônio $\left(\mathrm{NH}_{4}{ }^{+}\right)$}

$\mathrm{O}$ amônio em altas concentrações é um indicativo de que pode ocorrer uma oxidação para nitrato, aumentando assim, os teores dessa substância no meio. Além do saneamento in situ (fossas sépticas ou fossas rudimentares), o uso de fertilizantes agrícolas e a criação de animais constituem outras importantes fontes de amônio em água subterrânea. Com relação à potabilidade da água nota-se que o valor máximo permitido de amônio pela portaria 518 do Ministério da Saúde é $1,9 \mathrm{mg} / \mathrm{L}^{-1} \mathrm{NH}_{4}{ }^{+}-\mathrm{N}$ $\left(1,5 \mathrm{mg} / \mathrm{L}^{-1} \mathrm{NH}_{3}^{+}\right)(\mathrm{CABRAL}, 2007)$.

\section{- Cálcio $\left(\mathrm{Ca}^{+2}\right)$}

É o elemento mais abundante na maioria das águas e rochas. Seus sais possuem moderada a elevada solubilidade, sendo comum precipitar na forma de carbonato de 
cálcio $\left(\mathrm{CaCO}_{3}\right)$, mas de uma forma geral apresenta-se sob a forma de bicarbonato. Em águas subterrâneas seus valores variam entre 10 e 100 mg/L ${ }^{-1}$ (FEITOSA; MANOEL FILHO, 2000).

- Magnésio $\left(\mathrm{Mg}^{+2}\right)$

O magnésio possui propriedades análogas ao cálcio, diferindo na solubilidade, que é mais, e mais difícil para precipitar, também ocorre sob a forma geral de bicarbonato. Sua ocorrência é maior em rochas carbonatadas. Quanto ao teor, frequentemente estão entre 1 e 40 mg/L ${ }^{-1}$ (FEITOSA; MANOEL FILHO, 2000).

$\underline{\text { Annions }}$

- Fluoreto $\left(\mathrm{F}^{-}\right)$

A principal fonte de fluoretos em rochas ígneas é a fluorita, e geralmente são encontrados em pequenas concentrações, entre 0,1 e $1,5 \mathrm{mg} / \mathrm{L}^{-1}$ nas águas naturais. Possui solubilidade limitada e pouco contribui para a alcalinidade da água (FEITOSA; MANOEL FILHO, 2000).

- Cloreto $\left(\mathrm{Cl}^{-}\right)$

Este elemento é bastante solúvel e estável em solução, devido a este fato e ao lento movimento das águas no aquífero, o resultado é o aumento gradativo e constante dos teores de cloretos nas águas subterrâneas na direção do fluxo, apresentando valores inferiores a $100 \mathrm{mg} / \mathrm{L}^{-1}$ (FEITOSA; MANOEL FILHO, 2000).

O cloreto possui VMP de $250 \mathrm{mg} / \mathrm{L}^{-1}$ para as águas subterrâneas de Classe 1 e 2, que estão expressas na resolução CONAMA nº 396 (CONAMA, 2008).

\section{- Brometo $\left(\mathrm{Br}^{-}\right)$}

Seu comportamento é similar ao do íon cloreto $\left(\mathrm{Cl}^{-}\right)$, sendo que seu estudo tem interesse para o entendimento da origem das águas salgadas e em geral, ocorre com concentrações inferiores a $0,01 \mathrm{mg} / \mathrm{L}^{-1} \mathrm{em}$ águas doces (FEITOSA; MANOEL FILHO, 2000).

- Nitrato $\left(\mathrm{NO}_{3}^{-}\right)$

Em geral, tal ânion ocorre com pequeno teor e por ser móvel pode ser removido das camadas superiores do solo para a água, deste modo, os teores acima de $5 \mathrm{mg} / \mathrm{L}^{-1}$ podem ser indicativo de contaminação da água subterrânea por diversos motivos, como: esgotos, adubos nitrogenados, resíduos animais, entre outros (FEITOSA; MANOEL 
FILHO, 2000). Está expresso na resolução CONAMA n 396 que o VMP para este ânion é de $10 \mathrm{mg} / \mathrm{L}^{-1}$ para Classe 1 e 2 (CONAMA, 2008).

- Nitrito $\left(\mathrm{NO}_{2}^{-}\right)$

De acordo com Feitosa e Manoel Filho (2000) os resíduos de produtos proteicos provenientes de esgotos, fezes, entre outros são ricos em nitrogênio e se decompõe em nitratos na presença de oxigênio, de acordo com o ciclo do nitrogênio (nitrogênio orgânico, amônia, nitrito e nitrato).

A oxidação do amoníaco $\left(\mathrm{NH}_{3}\right)$ para nitrito $\left(\mathrm{NO}_{2}{ }^{-}\right)$ocorre com a participação de bactérias especializadas do grupo Nitrosomonas. A oxidação do nitrito para nitrato $\left(\mathrm{NO}_{3}{ }^{-}\right)$requer participação de bactérias autótrofas do grupo nitrobactérias. A presença de nitrito $\left(\mathrm{NO}_{2}^{-}\right)$na água subterrânea é indicativa de poluição.

A resolução CONAMA no 396 determina que o valor máximo permitido para este parâmetro seja de $1 \mathrm{mg} / \mathrm{L}^{-1}$ para Classe 1 e 2 (CONAMA, 2008).

- Fosfato $\left(\mathrm{PO}_{4}^{-3}\right)$

O fosfato possui forte tendência em fazer ligações formando compostos. Sua concentração varia de 0,01 a $10 \mathrm{mg} / \mathrm{L}^{-1}$. O fósforo proveniente por via antropogênica pode ser inserido nas águas subterrâneas por derivados de detergente, inseticidas e pesticidas (FEITOSA; MANOEL FILHO, 2000).

- Sulfato $\left(\mathrm{SO}_{4}^{-2}\right)$

Estes ânions são sais moderadamente solúveis a muito solúveis e se originam da oxidação do enxofre que estão presentes nas rochas e também da lixiviação de compostos sulfatados (gipsita e anidrita); e geralmente apresentam teores inferiores a $100 \mathrm{mg} / \mathrm{L}^{-1}$ (FEITOSA; MANOEL FILHO, 2000).

Na resolução CONAMA no 396 o VMP do sulfato para águas de Classe 1 e 2 é de $250 \mathrm{mg} / \mathrm{L}^{-1}$ (CONAMA, 2008). 


\section{3. ÁREA DE ESTUDO}

A Bacia Experimental do Rio Jardim foi escolhida devido a sua representatividade em relação às condições geoambientais (climáticas, geológicas, pedológicas, de relevo), pela facilidade do acesso, por estar inserida na região agrícola do Distrito Federal, e na porção central do bioma Cerrado (LIMA, 2007). Além, da existência dos poços já instalados, prontos para realização do monitoramento e de estudos que auxiliarão na discussão dos resultados desta pesquisa.

A Bacia Experimental do Alto Rio Jardim está situada na parte leste do Distrito Federal (Figura 1), entre as latitudes $15^{\circ} 40^{\prime}$ e $16^{\circ} 02^{\prime} \mathrm{W}$ e longitudes $47^{\circ} 20^{\prime}$ e $47^{\circ} 40^{\prime} \mathrm{S}$ (SPERA et al., 2002). Sua área de drenagem corresponde ao total de $104,86 \mathrm{~km}^{2}$, compreendendo duas sub-bacias, a do Córrego Estanislau $\left(49,71 \mathrm{~km}^{2}\right)$ e a do Rio Jardim $\left(55,15 \mathrm{~km}^{2}\right)$ (LIMA, 2010). As águas do Alto Rio Jardim, após desaguarem no rio Preto, seguem pelo rio Paracatu até o rio São Francisco nos limites do Distrito Federal (DOLABELLA, 1996).

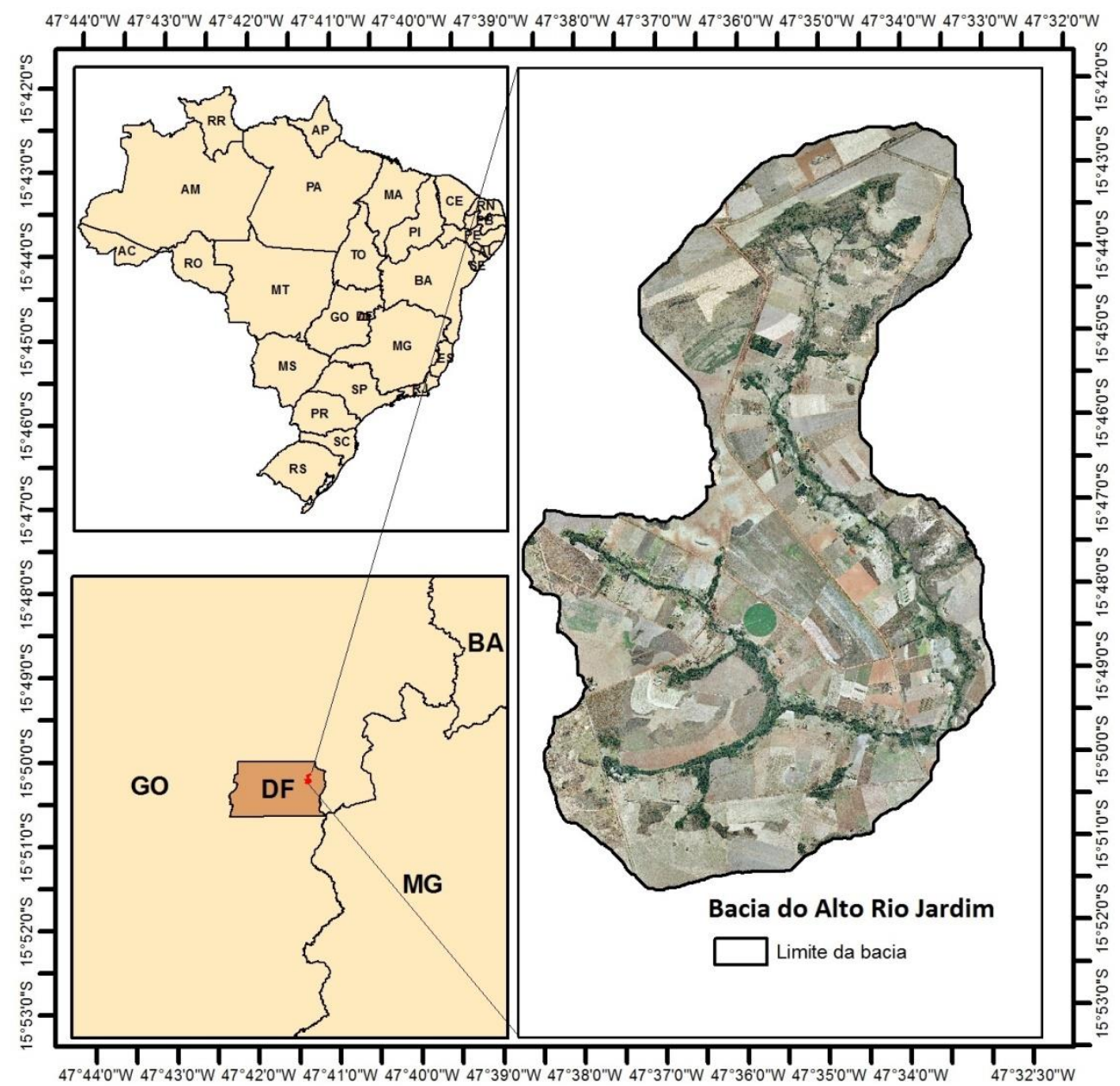

Figura 1 - Localização da Bacia Experimental do Alto Rio Jardim/ DF. 


\subsection{Geologia}

Segundo Feitosa e Manoel Filho (2000) em um sistema geológico, a natureza e a distribuição dos aquíferos e aquitardos são controladas pela litologia, estratigrafia e estrutura das formações geológicas. Assim sendo, a litologia corresponde à composição mineral (tamanho dos grãos, grau de compactação dos sedimentos). A estratigrafia refere-se às relações geométricas e cronológicas entre os elementos representativos do sistema geológico. E a estrutura enumera as características geométricas que surgem posteriormente, pela deformação (juntas, fraturas, falhas e dobras).

A geologia da região do Distrito Federal é composta por rochas metassedimentares dos grupos Canastra, Paranoá, Araxá e Bambuí. Ao estudar as águas subterrâneas de uma região é importante analisar a geologia local, pois a composição das águas é determinada pela composição das rochas. Assim, a BEARJ desenvolveu-se geologicamente sobre rochas dos grupos Bambuí, Canastra e Paranoá, como exposto na Figura 2 (FREITAS-SILVA e CAMPOS, 1998).

No Distrito Federal, o grupo Bambuí distribuiu-se na porção leste do Distrito Federal, sendo assim, a maior unidade na Bacia do Alto Rio Jardim (FREITAS-SILVA \& CAMPOS, 1998). Possui idade neo-proterozóica e "é composto por metassiltitos laminados, metassiltitos argilosos e bancos de arcóseos, com cor de alteração rosada/ avermelhada e com cor de rocha fresca em vários tons de verde" (CAMPOS, 2004).

O grupo aflora em drenagens e raros cortes de estradas, sendo sua maior área recoberta por uma espessa camada de latossolos. Localmente são observados bancos de arcóseos e siltitos verdes, quando frescos, e rosados ou amarronzados, quando alterados (LIMA, 2002). “Os aquíferos são livres, descontínuos lateralmente, anisotrópicos, de meio fissurado, com condutividade hidráulica baixa a média e importância hidrogeológica local relativa mediana, em função de extensa área de abrangência" (ARAÚJO, 2006).

De acordo com Freitas-Silva \& Campos (1998) o grupo Paranoá é determinado por uma sequência de psamo-pelito-carbonatada que se estende do Distrito Federal até a proximidade da confluência dos rios Paranã e Tocantins no Estado do Tocantins. Sua sedimentação ocorreu entre 950 e 1350 Ma, assim, posicionada no Meso- 
Neoproterozóico em ambiente marinho com condições plataformais epicontinentais e metamorfismo atribuído a este grupo é de baixo grau onde não houve a recristalização dos minerais serecita e clorita.

No Grupo Canastra as litologias são caracterizadas por fengita filitos, clorita filitos, quartzo-fengita-clorita-filitos, metarritmitos e filitos carbonosos. Quartzitos finos e micáceos ocorrem em níveis, centímetros a decamétricos, de maneira restrita e descontínua. Ainda ocorrem lentes de rochas carbonáticas representadas por mármores calcíticos, finos, cinza claro a escuros e maciços (Freitas-Silva \& Campos, 1998). Segundo Formaggio (2007) na Bacia do Alto Rio Jardim esse grupo ocorre na porção oeste da área, compondo a chapada divisora das bacias dos rios São Bartolomeu e Preto.

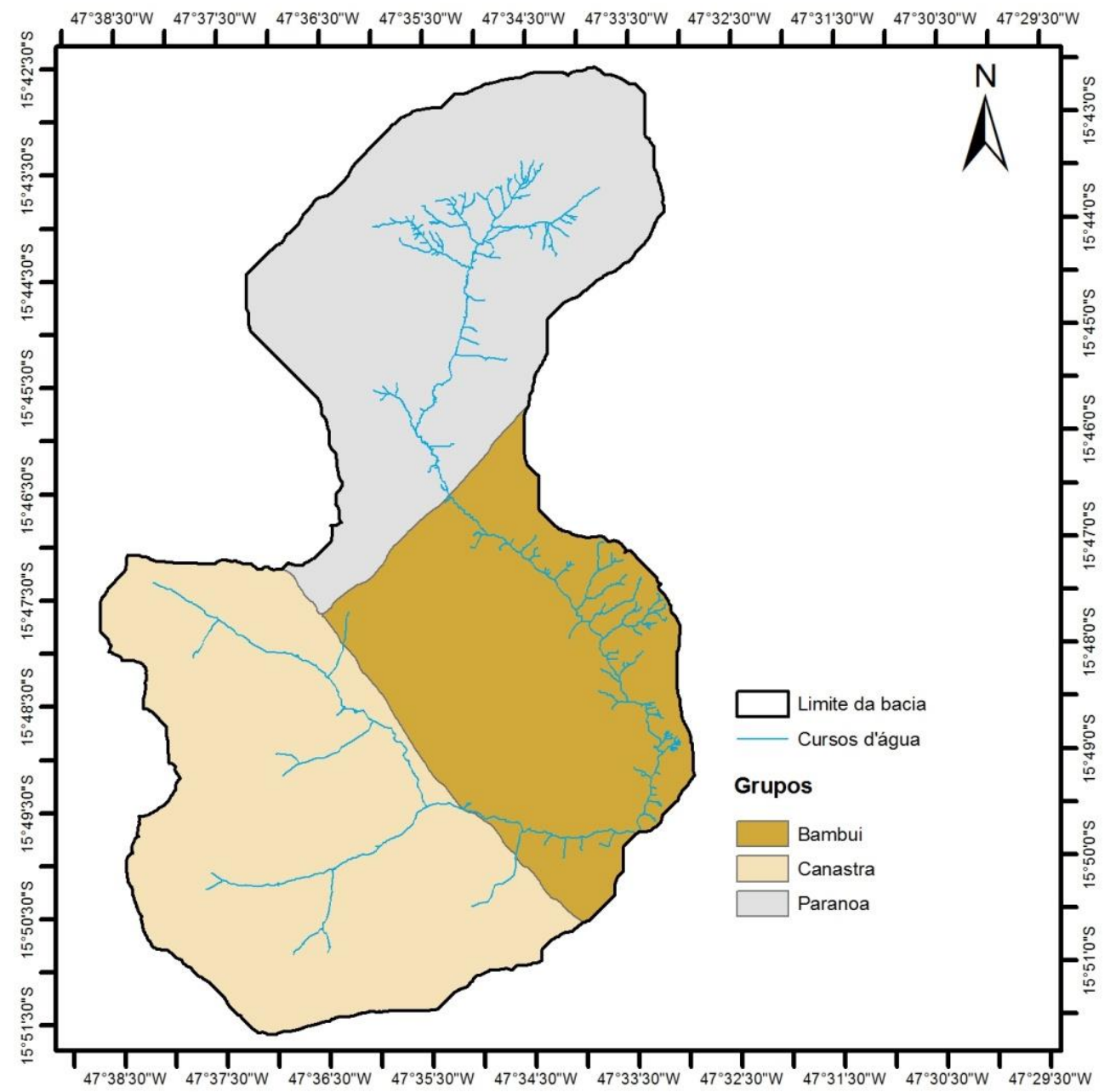

Figura 2 - Geologia da Bacia Experimental do Alto Rio Jardim (adaptado de Freitas-Silva \& Campos, 1998). 


\subsection{Hidrogeologia}

A hidrogeologia da Bacia do Alto Rio Jardim é formada, em seu domínio poroso, pelos sistemas P1, P2 e P4. Os subsistemas dos grupos Bambuí e Paranoá são o Q3/R3 e o R4 e, do Canastra o F.

Segundo Campos (2004) é no domínio poroso que ocorre a transição entre o meio externo e os aquíferos, e na zona saturada. Também sucedem os processos de recarga dos aquíferos, tanto rasos, quanto profundos, devido à água da chuva que se infiltra. Estas características contribuem para a manutenção da perenidade de drenagens no período de recessão de chuvas.

$\underline{\mathrm{P} 1}$

Este sistema caracteriza-se pelos aspectos pedológicos como, latossolo de textura arenosa majoritariamente, e como areias quartzosas (FREITAS-SILVA \& CAMPOS, 1998). "Esses latossolos são considerados produtos de alteração intempérica dos quartiztos Q3, parte dos metarritmitos R3 e das porções mais ricas em quartzitos do topo da unidade S, todos pertencentes ao Grupo Paranoá” (FORMAGGIO, 2007).

De acordo com Freitas-Silva \& Campos (1998) relevos onde predominantemente ocorrem chapadas elevadas, suavemente onduladas e recargas de aquíferos (intergranulares contínuos, livres, de grande extensão lateral) fraturados localiza-se esse tipo de sistema, abrangendo assim, a região norte da área de estudo.

O sistema P1 é caracterizado por grande espessura, maior que 5 metros, podendo chegar a cerca de 30 metros, e auxilia a compor um sistema com alta capacidade de armazenamento, devido as elevadas espessuras, que aprisionam a água até que ela percole por meio das fendas e fraturas, recarregando os aquíferos (ARAÚJO, 2006).

$\underline{\mathrm{P} 2}$

"Morfologicamente, está posicionado sobre terreno suave ondulado em chapadas intermediárias, fato que favorece a decomposição de rocha subjacente, originando uma espessa cobertura pedológica" (ARAÚJO, 2006). 
Este sistema caracteriza-se pelos aspectos pedológicos como, latossolo vermelhos arenosos a argilosos, possuindo textura granular e esta característica lhe confere porosidade e condutividade hidráulica moderada (FREITAS-SILVA \& CAMPOS, 1998).

É composto por aquíferos intergranulares, contínuos, livres, de grande distribuição lateral e as couraças lateríticas porosas que o compõem lhe confere um importante fator de recarga local (ARAÚJO, 2006).

\section{$\underline{\mathrm{P} 4}$}

Este sistema abrange a porção sudeste da área, ocupando toda a parte mais rebaixada, e caracteriza-se pedologicamente por cambissolos e neossolos litólicos. Possui aquíferos intergranulares, descontínuos, livres e muito restritos lateralmente, situam-se em relevos movimentados, escavados em vales dissecados com forma de relevos côncavos e convexos e desníveis significativos (ARAÚJO, 2007).

Relacionado a estas características, observa-se que a região não apresenta condições favoráveis para a recarga local, consequentemente aumenta-se o escoamento superficial, reforçando-o devido aos solos argilosos também presentes, que são pouco permeáveis (ARAÚJO, 2007).

- Subsistema R3/Q3

"Os metarritmitos da unidade $\mathbf{R 3}$ são caracterizados por intercalações irregulares de quartzitos finos, brancos e laminados com camadas de metassiltitos, metalamitos e metassiltitos argilosos" (CAMPOS, 2004).

“A Unidade Q3 é composta por quartzitos finos a médios, silicificados e intensamente fraturados. Apresentam estratificações cruzadas variadas e mais raramente marcas onduladas. Sustenta o relevo de chapadas elevadas em cotas superiores a 1.200 m" (CAMPOS, 2004).

Este subsistema possui comportamento rúptil, devido ao tipo litológico existente (quartzitos), desta forma, ocorrem descontinuidades por todo maciço rochoso, ocasionando abertura do sistema de fraturas (ARAÚJO, 2006). 


\section{- Subsistema R4}

"São constituídos por intercalações regulares de quartzitos e metapelitos, com espessuras bastante regulares da ordem de 1 a $3 \mathrm{~cm}$. Apenas raramente são discriminados pacotes decimétricos de metassiltitos maciços” (CAMPOS, 2004).

Segundo Araújo (2006) os poços integrados a este sistema possuem problemas construtivos, decorrente das feições de intemperismo diferencial. Também, é comum a ocorrência de níveis pelíticos (baixa resistência ao intemperismo) abaixo dos metarritmitos (elevadas ressistência aos processos intempéricos).

\section{- Subsistema F}

Segundo Campos (2004) este subsistema é constituído basicamente por filitos (rocha metassedimentar muito fina) variados, os quais incluem clorita filitos, quartzo-fengita filitos e clorita-carbonato filitos. Além dos filitos ocorrem mármores finos cinza-claros e quartzitos finos silicificados e cataclasados.

Devido a estas características, este subsistema é propenso a formar bons sistemas aquíferos, como a ocorrência de sistemas de fraturamentos, promovendo a percolação da água da chuva (ARAÚJO, 2006).

\subsection{Clima}

Segundo a classificação de Köppen - Geiger, o clima na área de estudo é do tipo Aw, essa nomenclatura se refere ao clima tropical. Ou seja, apresenta duas estações bem definidas; inverno seco, com baixos índices pluviométricos, baixa umidade do ar e alta taxa de evaporação, este período compreende de maio a outubro; e verão chuvoso, com altos índices pluviométricos, aumento da umidade do ar, abarcando os demais meses do ano.

“A precipitação média na área varia entre 1.000 mm a 1.700 mm, aproximadamente, sendo que mais de $80 \%$ da chuva, em geral, ocorre entre os meses de outubro a março" (LIMA, 2010). 


\subsection{Relevo}

A Bacia do Alto Rio Jardim apresenta baixa declividade quase ao longo de toda bacia, como demonstrado na Figura 3, onde varia de 0,0 a 4,83 graus na maior parte da área. Situa-se sobre relevo que varia de plano a forte ondulado, de acordo com Reatto et al. (2000) esta variação ocorre da seguinte forma: $54,87 \%$ plano; $16,95 \%$ ondulado; $15,74 \%$ suave ondulado; $12,40 \%$ plano e $0,05 \%$ forte ondulado a escarpado.

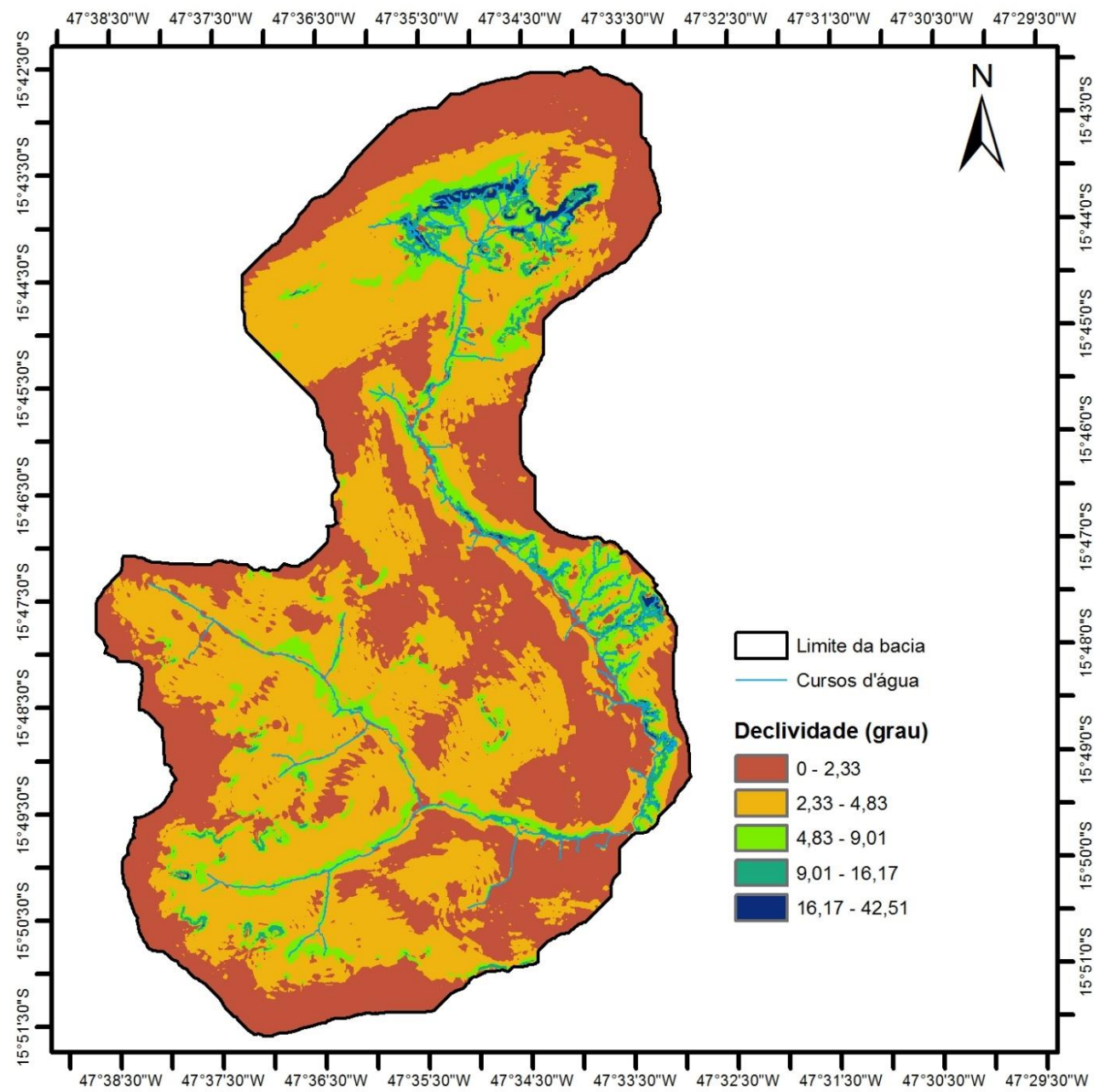

Figura 3 - Declividade da Bacia Experimental do Alto Rio Jardim.

\subsection{Solos}

De acordo com o levantamento de solos do Distrito Federal realizado pela EMBRAPA (1978), na região do Alto Jardim ocorrem de forma dominante Latossolo Vermelho, Latossolo Vermelho-Amarelo e Cambissolo. Reatto et al. (2000) realizaram o levantamento semi-detalhado dos solos do Alto Rio Jardim, e a partir deste trabalho 
Lima et al. (2007) analisaram a ocorrência dos tipos de solo na bacia. Observaram que a região é predominantemente composta por Latossolos $(76,38 \%)$, seguido de Cambissolos (16,68\%), Plintossolo (2,54\%), Gleissolo (2,41\%), Neossolo Quartzarênico (2,09\%) e, uma parcela de Afloramentos de Rocha (0,24\%). A Figura 4 representa o estudo semi-detalhado (1:50.000) dos solos da bacia.

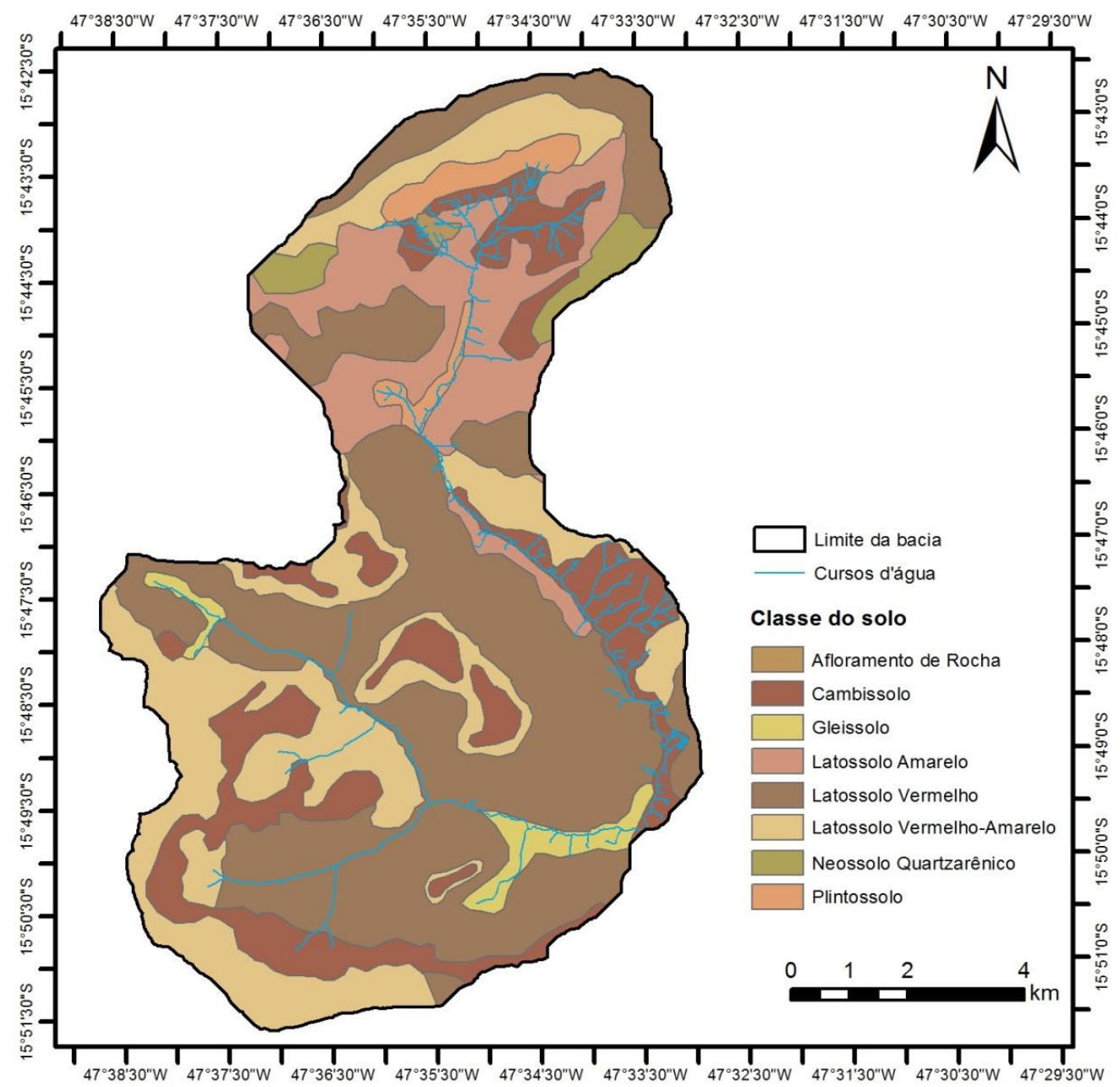

Figura 4 - Classe dos solos da Bacia Experimental do Alto Rio Jardim (adaptado de Reatto et al., 2000).

\section{- CLASSES}

\section{$\underline{\text { Latossolo }}$}

"Latossolos são solos altamente intemperizados, resultantes da remoção de sílica e de bases trocáveis do perfil. Grande parte dos minerais existentes, nesses solos, são os secundários, constituintes da fração argila" (REATTO et al., 2000).

Morfologicamente são solos minerais, não hidromórficos, profundos (superiores a $1,5 \mathrm{~m})$ apresentando horizonte B espesso $(>50 \mathrm{~cm})$. As estruturas predominantes são 
maciças ou em blocos subangulares (pouco desenvolvidos) ou em forma muito pequena granular.

\section{- LATOSSOLO VERMELHO (LV)}

"Possuem cores, variando de bruno-avermelhado no horizonte A a vermelho no horizonte B. Fisicamente, possuem teor de argila, variando entre 67\% e 75\%. São solos acentuadamente drenados a bem drenados, com alta permeabilidade de água" (REATTO et al. 2000).

\section{- LATOSSOLO AMARELO (LA)}

"Suas cores variam de bruno-avermelhado no horizonte A, e bruno-avermelhado a vermelho-amarelado no horizonte B. Em seus aspectos físicos, apresentam teor de argila, variando entre $55 \%$ e $59 \%$. São solos acentuadamente drenados" (REATTO et al. 2000).

\section{- LATOSSOLO VERMELHO-AMARELO (LVA)}

"Possuem cores, variando de bruno-escuro a no horizonte A, e bruno-forte no horizonte B. No que se refere aos aspectos físicos, possuem teor de argila, variando entre $38 \%$ e $71 \%$. São solos acentuadamente drenados a bem drenados" (REATTO et al. 2000).

\section{$\underline{\text { Cambissolo (C) }}$}

Estes solos sofreram pouca alteração física e química em seu horizonte subsuperficial, porém, esta, fez desenvolver sua cor e estrutura. Ocupam os relevos suave-ondulados ( $3 \%$ a $8 \%$ de declive) e fisicamente variam no que diz respeito à textura, onde seu teor de argila varia entre $46 \%$ a $63 \%$. O cambissolo, quimicamente, pode ser distróficos, ou seja, com saturação por bases entre $28 \%$ e $76 \%$ e saturação por alumínio entre $0 \%$ e $33 \%$ (REATTO, 2000).

\section{$\underline{\text { Plintossolo (PT) }}$}

Estes solos são minerais hidromórficos, possuindo restrição à percolação da água, consequentemente alagamentos temporários e escoamento lento são frequentes. A ocorrência do plintossolo é predominantemente em relevo plano e suave-ondulado, áreas deprimidas, e nos terços inferiores da encosta, onde há importante movimentação lateral de água. Morfologicamente, apresentam horizonte de subsuperfície, com 
manchas avermelhadas, distribuídas no perfil de aspecto variegado (resultado da concentração de ferro do solo), chamadas de plintita. Quimicamente, apresenta $6 \%$ de saturação por bases e $32 \%$ de saturação por alumínio, classificado como distrófico (ocorre inversão de cargas a partir de $45 \mathrm{~cm}$ de profundidade) (REATTO, 2000).

\section{$\underline{\text { Gleissolos }(\mathrm{G})}$}

Solos hidromórficos ocupam as depressões da paisagem, sujeitas a inundações, apresentam má drenagem e, possui, com frequência, camada escura espessa de matéria orgânica mal decomposta sobre uma camada acinzentada. De acordo com Reatto et al. (2000) estes solos são pouco desenvolvidos e formaram-se de sedimentos aluviais, com presença de lençol freático próximo à superfície na maior parte do ano, caracterizando um ambiente de acúmulo de matéria orgânica e de oxirredução. Fisicamente, apresentam textura bastante variável ao longo do perfil, sendo solos bem estruturados. Quimicamente, podem ser ricos ou pobres em bases ou com teores de alumínio elevados.

\section{Neossolos - NEOSSOLO FLÚVICO (RU)}

Segundo Reatto et al. (2000) os neossolos são pouco evoluídos, não hidromórficos e formados em depósitos aluviais recentes, apresentando horizonte A, seguido de uma sucessão de camadas estratificadas, sem relação pedogenética entre si. Sua ocorrência se dá em relevo plano e estão sob a fitofisionomia Mata de Galeria. Fisicamente, apresentam teor de argila de $46 \%$ e quimicamente são álicos (baixo potencial nutricional), com saturação por alumínio de $81,47 \%$ e saturação por bases $8,27 \%$.

\section{- Textura}

Uma característica bastante relevante no que diz respeito ao solo é a textura, pois esta determina o grau de coesão e adesão entre as partículas do solo. Os teores resultantes influenciam a taxa de infiltração e retenção do solo, na aeração e na disponibilidade de nutrientes (FORSYTHE, 1975). Santos et al. (2010) expõem que a determinação da textura auxilia no uso mais racional e eficiente dos fertilizantes.

A Figura 5 apresenta a textura do solo da área de estudo, onde predominantemente apresenta textura argilosa $(71,84 \%)$, seguido de muito argilosa $(15,44 \%)$ e média $(10,41 \%)$, a textura arenosa compõe uma pequena parte $(2,07 \%)$. 


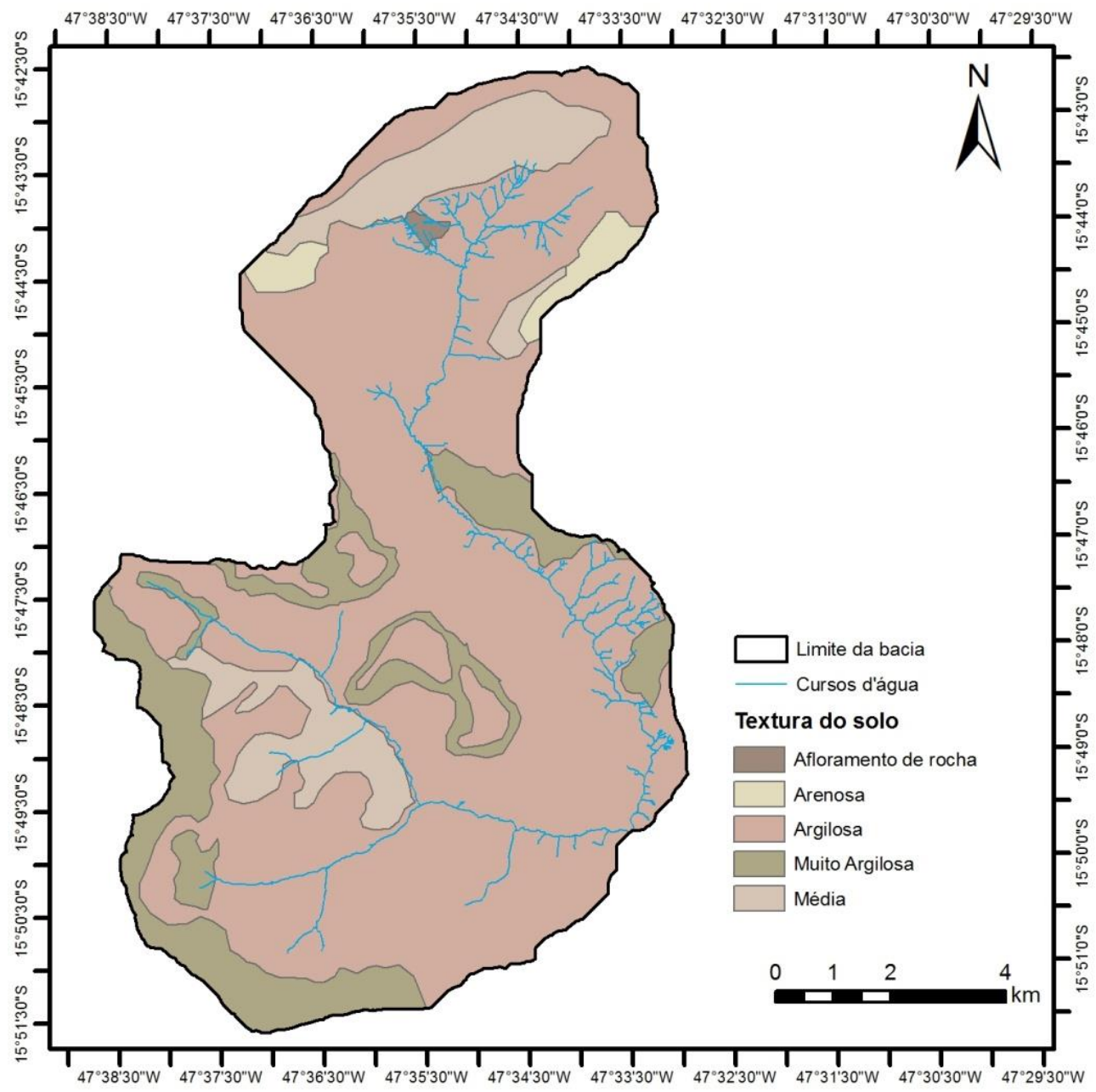

Figura 5 - Textura dos solos da Bacia Experimental do Alto Rio Jardim (adaptado de Reatto $e t$ al., 2000). 


\section{MATERIAIS E MÉTODOS}

A metodologia desta pesquisa foi dividida em 5 tópicos. Primeiramente, explicam-se as técnicas utilizadas para a obtenção dos dados de campo; no item 2, os tratamentos estatísticos empregados nos dados de qualidade da água. No terceiro item desenvolveu se a delimitação das áreas de drenagens; item 4 se apresentou como foi realizada a vetorização e classificação do mapa de uso e ocupação da terra da Bacia do Alto Rio Jardim e finalizando, o quinto item descreve as análises estatísticas definidas para se chegar aos objetivos propostos neste estudo.

\subsection{Levantamento dos Dados}

As amostras de água foram coletadas nos poços piezométricos instalados por toda a Bacia do Alto Rio Jardim (Figura 6), no total são 55 poços. Entretanto, houve coleta somente em 45 destes poços, por conta de fatores externos como: queimadas, canos entortados, quebrados e do nível do lençol freático, desta forma, a cada mês a quantidade de poços amostrados sofreu variação.

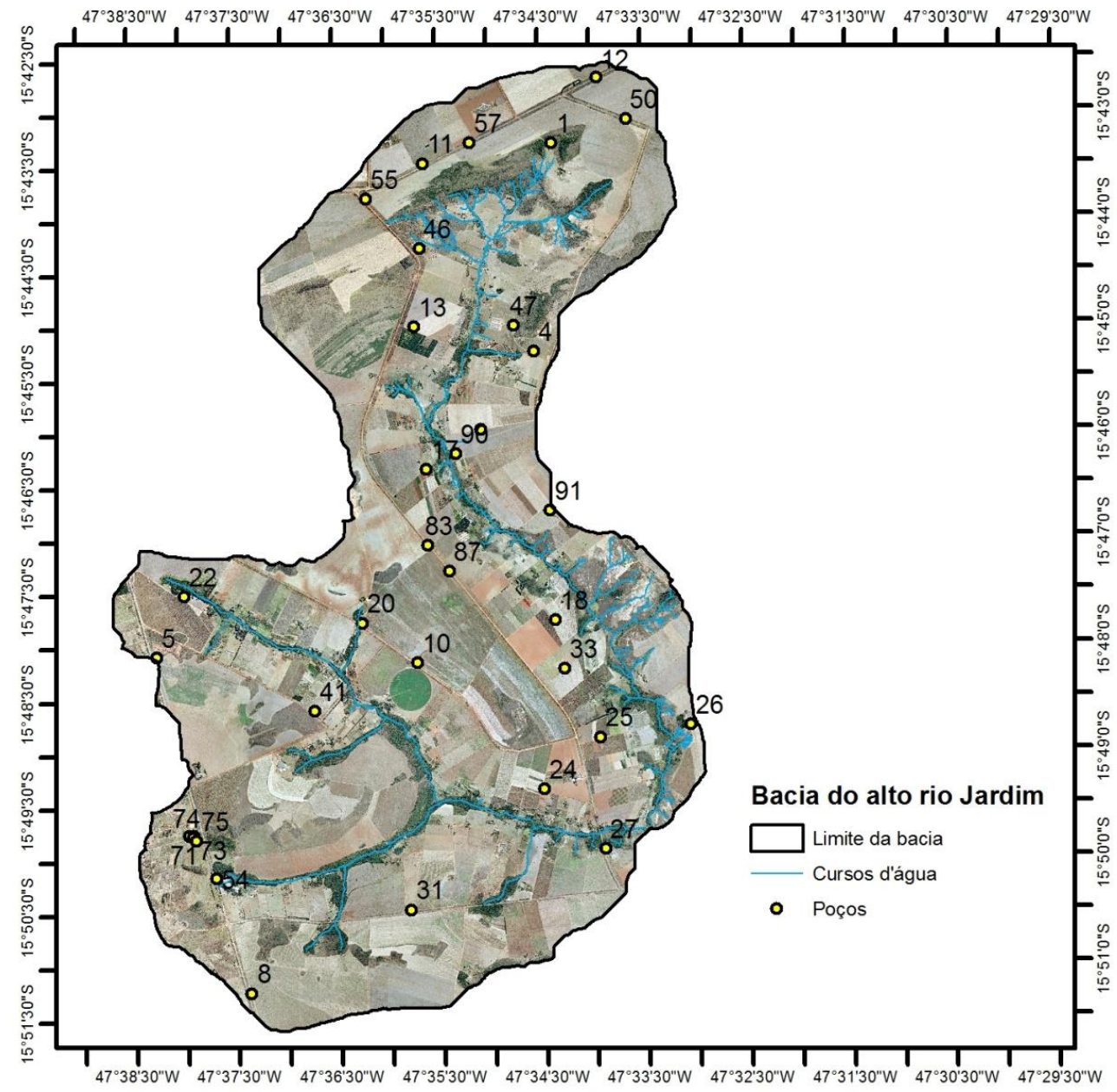

Figura 6 - Limite da BEARJ com pontos dos poços alocados. 
As amostras foram coletadas de julho de 2014 até junho do ano de 2015, completando assim, 1 (um) ano hidrológico. O dia da coleta foi sistematizado para a segunda semana de cada mês, para que houvesse periodicidade.

Nos poços subterrâneos foi utilizado para a coleta da água, amostrador de PVC, tipo bailer (Figura 7a), e para cada campanha mensal foi realizada sua devida lavagem. Após a coleta (Figura 7b), a água foi transferida para frascos de polietileno, previamente lavados com detergente específico (Figura 7c). A limpeza dos recipientes é de suma importância para evitar a contaminação da amostra, um exemplo disso é o uso de detergentes comuns, deste modo, a lavagem deve ser eficaz para a limpeza e não acrescentar interferentes (CETESB, 2011).

Os frascos foram acondicionados em uma caixa térmica, sob-refrigeração, para a preservação da amostra, retardando assim, alterações químicas e biológicas que ocorrem após a retirada das mesmas do ambiente. E, posteriormente são levados ao laboratório para as devidas análises serem realizadas em cada amostra coletada.
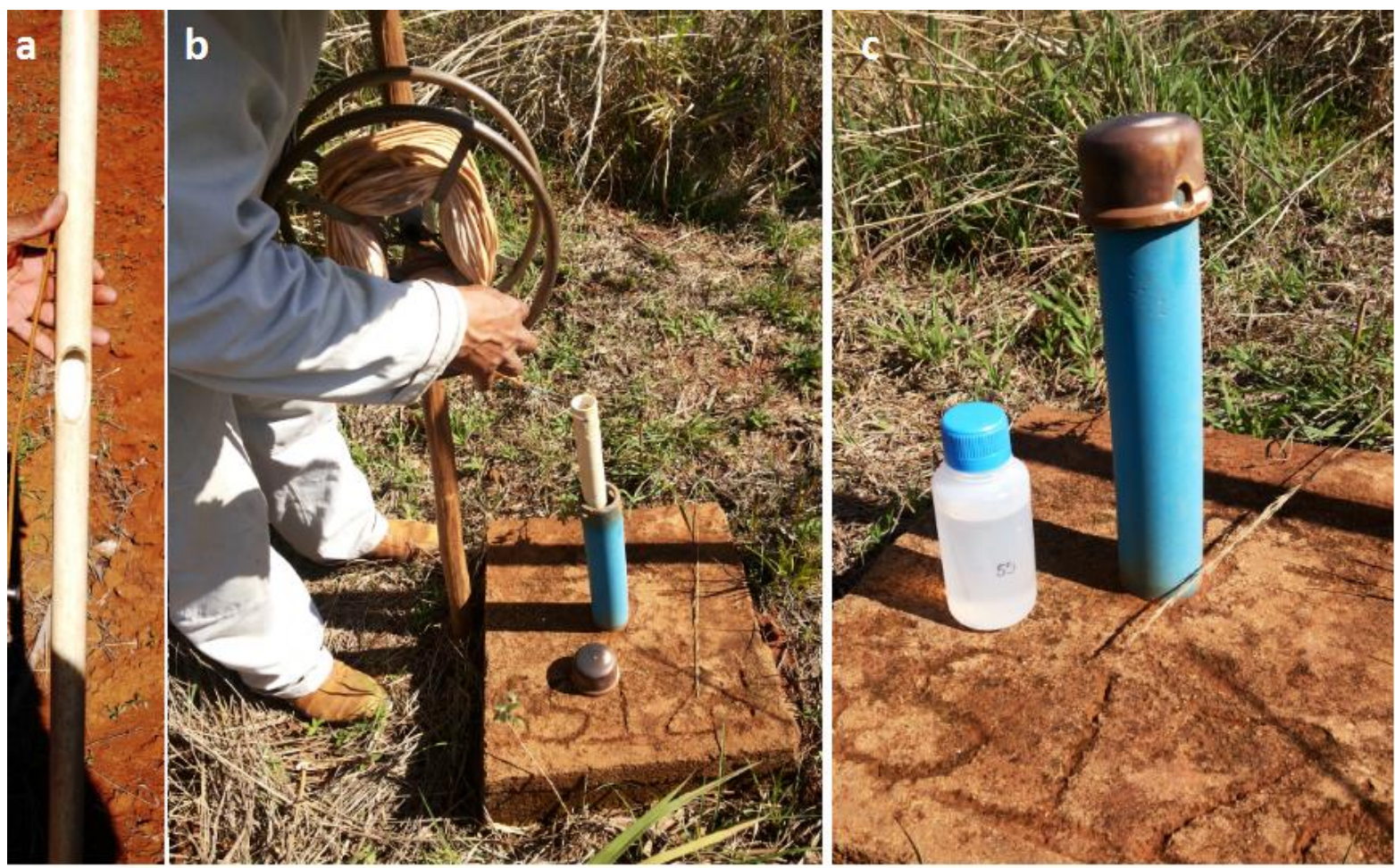

Figura 7 - a) Amostrador de PVC (tipo bailer), b) coleta e c) amostras nos frascos de polietileno. 
Os procedimentos de análises foram realizados no Laboratório de Química de Água da Empresa Brasileira de Pesquisa Agropecuária - EMBRAPA Cerrados, em conformidade com o Standard Methods for the Examination of Water and Wastewater SMEWW (APHA, 2005).

Todos os procedimentos de coleta e preservação de amostras foram realizados de acordo com o guia nacional de coleta e preservação de amostras: água, sedimento, comunidades aquáticas e efluentes líquidos (CETESB, 2011).

Para cada amostra coletada foram feitas determinações de 20 parâmetros: condutividade elétrica (CE), sólidos dissolvidos totais (SDT), salinidade, pH, alcalinidade, bicarbonato, dureza, fósforo solúvel (Ps); dos íons cloreto $\left(\mathrm{Cl}^{-}\right)$, fluoreto $\left(\mathrm{F}^{-}\right)$, nitrato $\left(\mathrm{NO}_{3}^{-}\right)$, nitrito $\left(\mathrm{NO}_{2}^{-}\right)$, fosfato $\left(\mathrm{PO}_{4}{ }^{3^{-}}\right)$, sulfato $\left(\mathrm{SO}_{4}^{2^{-}}\right)$, brometo $\left(\mathrm{Br}^{-}\right)$, sódio $\left(\mathrm{Na}^{+}\right)$, potássio $\left(\mathrm{K}^{+}\right)$, amônio $\left(\mathrm{NH}_{4}^{+}\right)$, cálcio $\left(\mathrm{Ca}^{2+}\right)$, magnésio $\left(\mathrm{Mg}^{2+}\right)$ e lítio $\left(\mathrm{Li}^{+}\right)$.

As amostras foram analisadas o mais rapidamente possível, quando da sua chegada ao laboratório; entretanto, em determinadas situações, as amostras que possuem prazo de validade mais longo podem ser armazenadas em câmara fria ou geladeira até o momento do ensaio (CETESB, 2011).

Desta forma, no laboratório inicialmente foi realizada a medição dos parâmetros de condutividade elétrica, sólidos dissolvidos totais (SDT), salinidade e $\mathrm{pH}$ utilizando o medidor multiparâmetros sension 156, da marca HACH (Figura 8). O equipamento foi devidamente calibrado para a medição dos parâmetros.

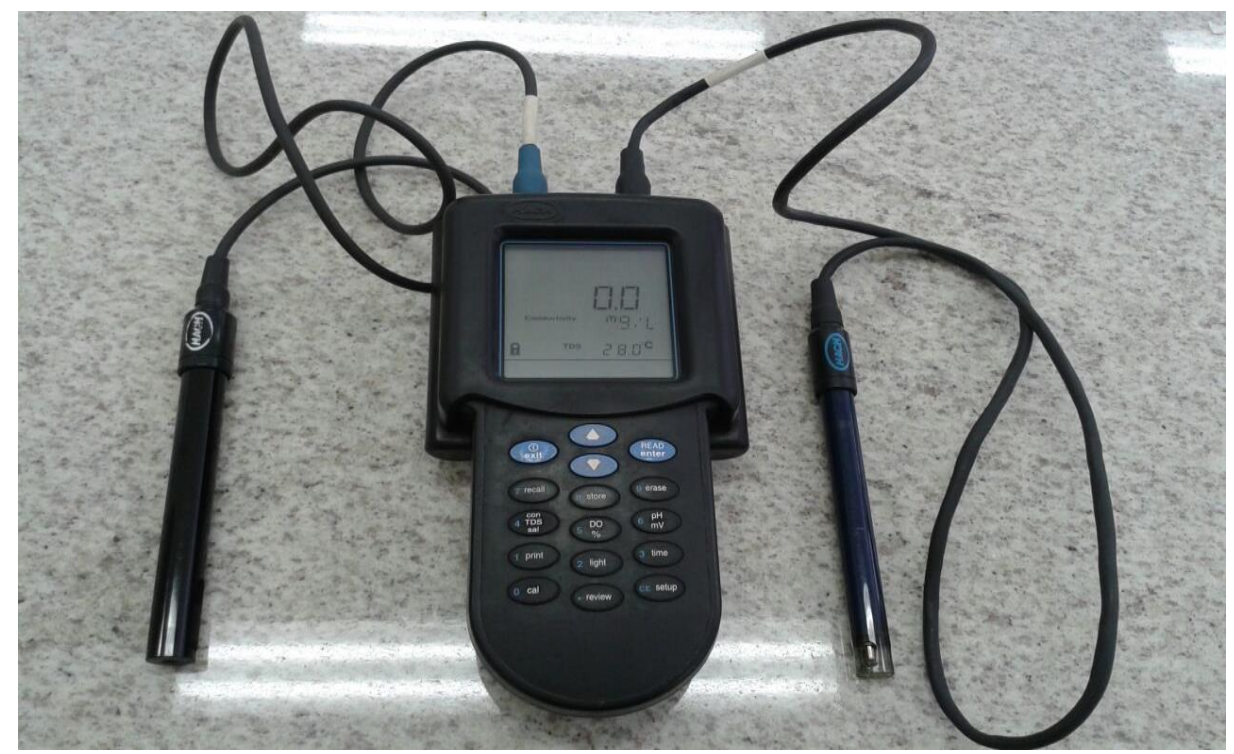

Figura 8 - Sonda multiparâmetros Sension 156, marca HACH. 
A alcalinidade das amostras foi determinada pelo método titulométrico (APHA, 2005), utilizando o Titulador automático 876 dosimat plus/dosímetro, da marca Metrohm (Figura 9). Os íons hidroxila resultantes da dissociação ou da hidrólise de substâncias são neutralizados com ácido-padrão (ácido sulfúrico 0,0200 N), por titulação utilizando indicador misto vermelho de metila mais verde de bromocresol.

O procedimento consiste na transferência de $100 \mathrm{ml}$ da água coletada, utilizando a proveta, para os frascos Erlenmayer e adicionado 3 (três) gotas do indicador misto. Após, o frasco é colocado no titulador automático e avolumata-o com a solução de ácido sulfúrico $0,02 \mathrm{~N}$ e titula-se, com agitação constante da amostra, até que se observa a mudança de cor da amostra de azul-claro para rosa-claro. O cálculo da alcalinidade é expresso pela Eq. 1 abaixo.

$$
\text { Alcalinidade }\left(\mathrm{mg} / \mathrm{L} \mathrm{CaCO}_{3}\right)=\frac{\mathrm{M} \mathrm{H}_{2} \mathrm{SO}_{4}}{V \text { amostra }} \times 100.000
$$

onde o número 100.000 representa o peso molecular do $\mathrm{CaCO}_{3}$ expresso em mg. Para $\mathrm{M} \mathrm{H}_{2} \mathrm{SO}_{4}=0,01 \mathrm{e} \mathrm{V}$ amostra $=100 \mathrm{~mL}$, pode-se concluir que para o cálculo da alcalinidade, para estas condições, basta multiplicar o resultado da titulação por 10 .

A análise do bicarbonato também é realizada por meio do método titulométrico no mesmo procedimento da alcalinidade, após, o valor encontrado é inserido na Eq. 2 (DEUTSCH, 1997) descrita abaixo, juntamente com o valor do $\mathrm{pH}$.

$$
\text { Bicarbonato }(\mathrm{mg} / \mathrm{L})=\frac{\text { alcalinidade } \times 61}{1+\left(\frac{2 \times 10^{-10,3}}{10^{-p H}}\right) \times 50}
$$




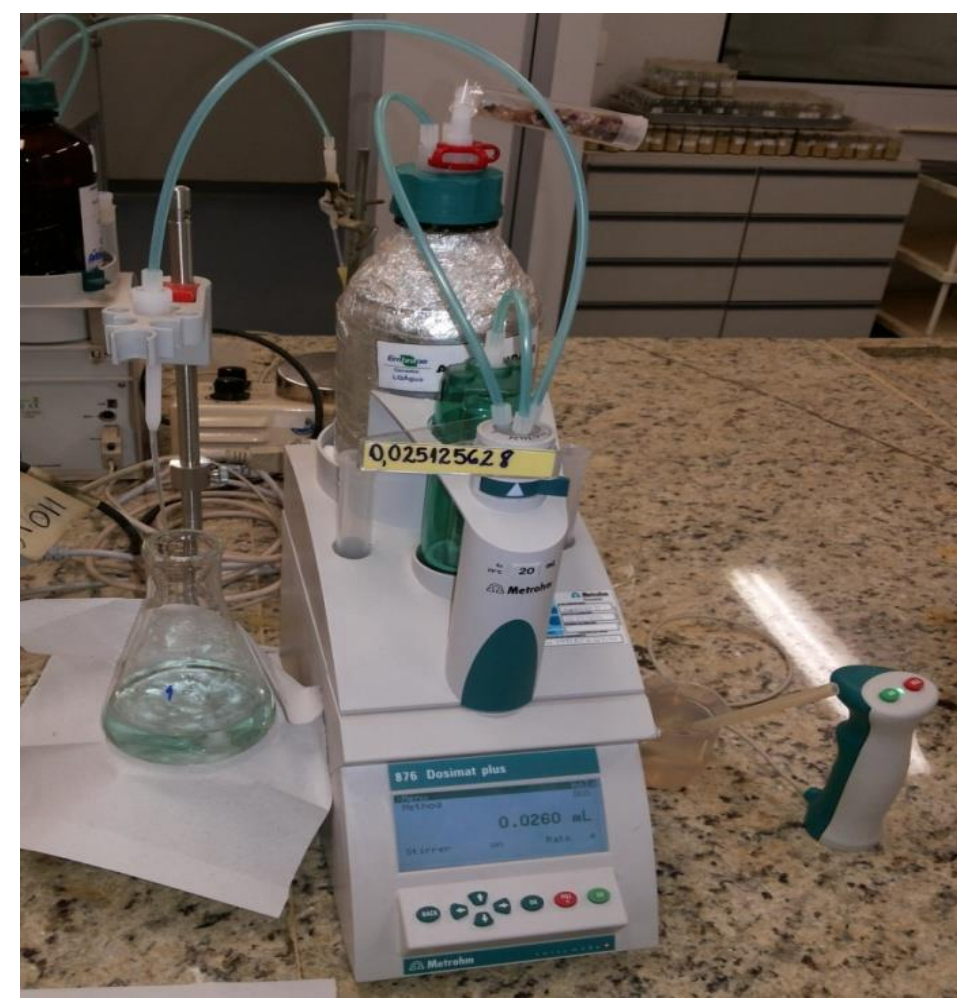

Figura 9 - Titulador automático 876 dosimat plus/dosímetro, marca METROHM.

Em um segundo momento as amostras destinadas a análise iônica e ao fósforo solúvel foram filtradas por meio da bomba de filtração (Figura 10), em membrana hidrofílica, constituída por misturas de ésteres de celulose com porosidade de 0,45 $\mu \mathrm{m}$ e congeladas até o momento da leitura.

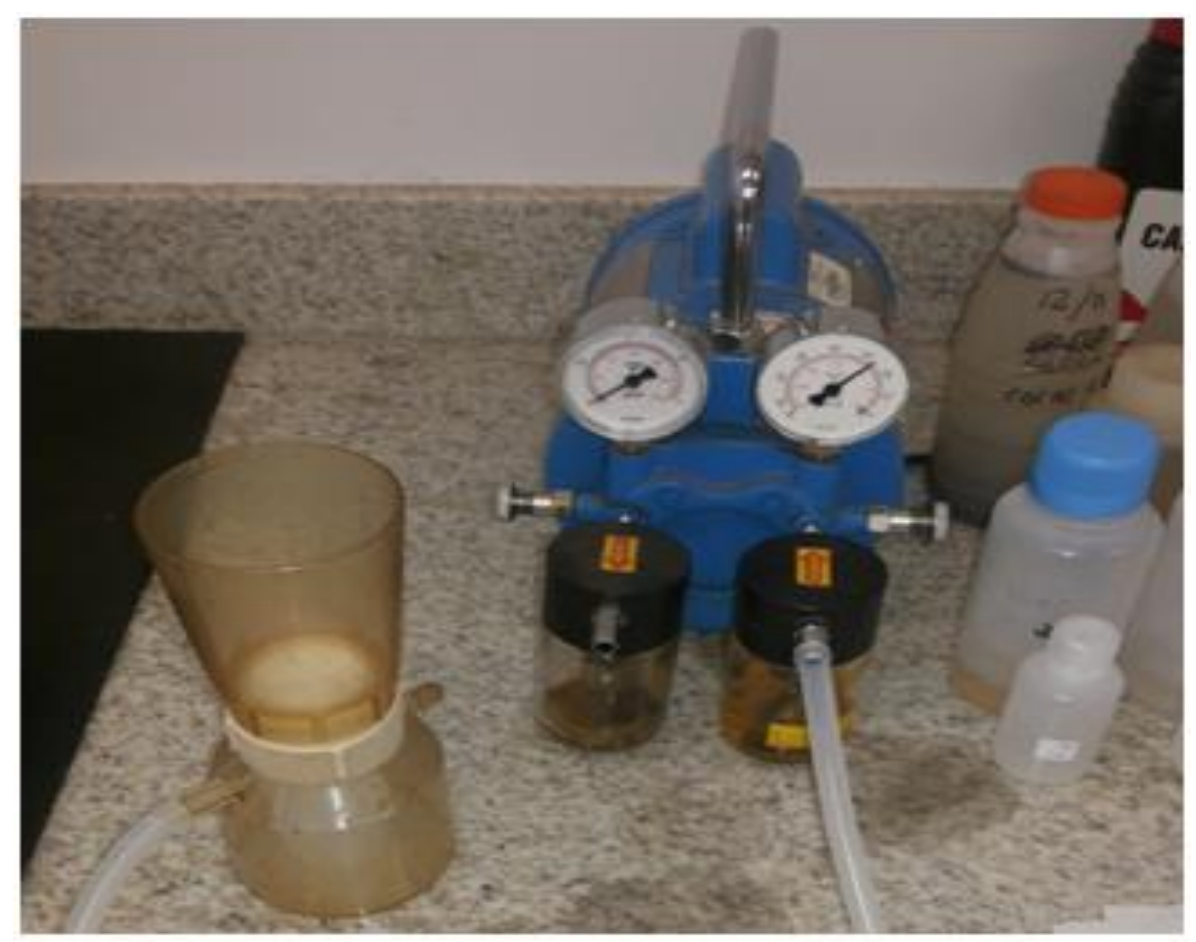

Figura 10 - Filtragem das amostras. 
Para análise de fósforo solúvel foi utilizado o método ácido ascórbico/colorimétrico (APHA, 2005). O método baseia-se na reação de molibdato de amônio e o antimoniltartarato de potássio em meio ácido com o fósforo (na forma de ortofosfato) presente na amostra, com a formação do ácido fosfomolíbdico que é reduzido a molibdeno azul através do ácido ascórbico. A absorbância medida em espectrofotômetro UV/Vis a $882 \mathrm{~nm}$ é proporcional à concentração de ortofosfato na amostra. Para leitura do fósforo solúvel foi utilizado um Espectrofotômetro, com cubeta de $1 \mathrm{~cm}$, modelo UV-1800, Shimadzu (Figura 12).

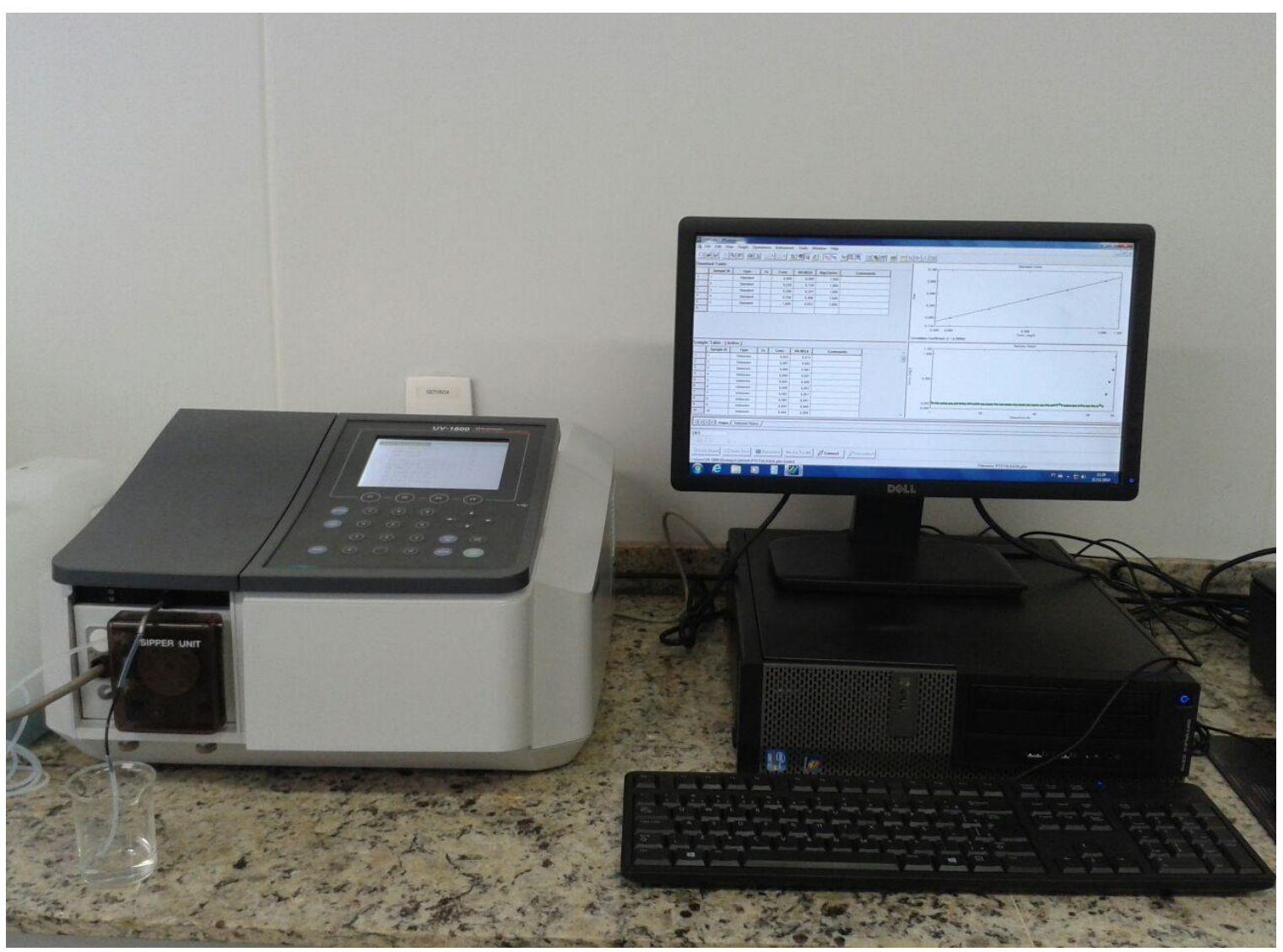

Figura 11 - Espectrofotômetro modelo UV-1800, marca SHIMADZU.

$\mathrm{Na}$ análise dos cátions e ânions foi utilizado o Cromatógrafo Iônico, modelo 761 Compact IC, METHROHM (Figura 12). A cromatografia iônica é um método cromatográfico que aplica princípios da troca iônica, de modo que a condutividade elétrica é utilizada para a detecção e determinação quantitativa dos íons em solução (FRANKENBERGER-JR. et al., 1990). Para análise de cátions foi utilizada uma coluna de troca iônica Metrosep C2 e como eluente uma solução tampão de 4,0 mM de Ácido Tartárico, e 0,75 mM de Ácido Dipicolínico (ácido 2,6-piridinodicarboxílico). Na 
análise de cátions foi utilizada uma coluna Metrosep Asup5 e solução tampão de 3,2 $\mathrm{mM}$ de bicarbonato de sódio e 1,0 $\mathrm{mM}$ de hidrogenocarbonato de sódio e ainda uma solução supressora de $100 \mathrm{mM}$ de ácido sulfúrico utilizada no ramal da supressão iônica, paralelamente à água bidestilada, com um gradiente pré-fixado em 50\% (água/ácido).

$\mathrm{Na}$ análise da dureza da água a Eq. 3 foi utilizada, a partir dos valores do cálcio e magnésio, obtidos por meio da cromatografia (APHA, 2000):

Dureza em mg/L ${ }^{-1}$ de $\mathrm{CaCO}_{3}=2,497[\mathrm{Ca} \mathrm{mg} / \mathrm{L}]+4,118\left[\mathrm{Mg} \mathrm{mg} / \mathrm{L}^{-1}\right]$

onde mg: miligrama; L: litro; $\mathrm{CaCO}_{3}$ : carbonato de cálcio; $\mathrm{Ca}$ : cálcio e $\mathrm{Mg}$ : magnésio.

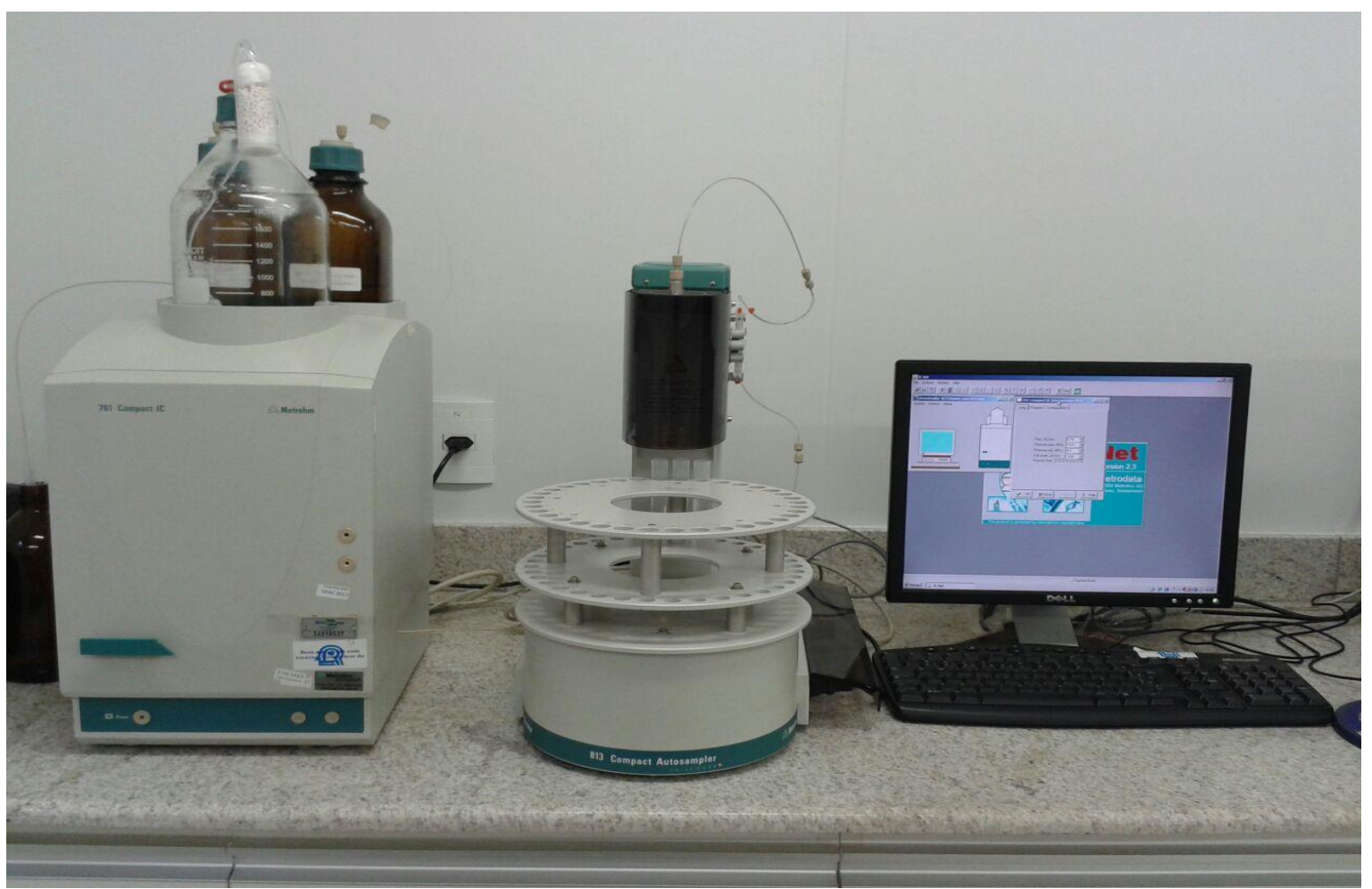

Figura 12 - Cromatógrafo Iônico modelo 761 Compact IC, marca METHROHM.

Na Tabela 1 é apresentado um resumo de todos os parâmetros analisados e suas respectivas unidades, métodos e aparelhos utilizados em sua análise. 
Tabela 1 - Parâmetros monitorados e seus respectivos métodos de análise.

\begin{tabular}{|c|c|c|c|}
\hline PARÂMETROS & UNIDADE & MÉTODO & APARELHO \\
\hline $\begin{array}{c}\text { CONDUTIVIDADE } \\
\text { ELÉTRICA }\end{array}$ & $\mu \mathrm{S} / \mathrm{cm}^{-1}$ & SM 2510 & $\begin{array}{l}\text { Medidor multiparâmetros } \\
\text { sension } 156 \text { - HACH }\end{array}$ \\
\hline $\begin{array}{c}\text { SÓLIDOS } \\
\text { DISSOLVIDOS } \\
\text { TOTAIS }\end{array}$ & $\mathrm{mg} / \mathrm{L}^{-1}$ & SM 2540 & $\begin{array}{l}\text { Medidor multiparâmetros } \\
\text { sension } 156 \text { - HACH }\end{array}$ \\
\hline SALINIDADE & $\%$ & SM 2520 & $\begin{array}{c}\text { Medidor multiparâmetros } \\
\text { sension } 156 \text { - HACH }\end{array}$ \\
\hline $\mathbf{p H}$ & - & SM 4500 - H+ & $\begin{array}{l}\text { Medidor multiparâmetros } \\
\text { sension } 156 \text { - HACH }\end{array}$ \\
\hline ALCALINIDADE & $\mathrm{mg} \mathrm{CaCO} / \mathrm{L}^{-1}$ & SM 2320 & $\begin{array}{c}\text { Titulador automático } 876 \\
\text { dosimat plus/dosímetro - } \\
\text { METROHM }\end{array}$ \\
\hline BICARBONATO & $\mathrm{mg} / \mathrm{L}^{-1}$ & SM 2320 & $\begin{array}{c}\text { Titulador automático } 876 \\
\text { dosimat plus/dosímetro - } \\
\text { METROHM }\end{array}$ \\
\hline FÓSFORO & ppm & SM 4500 - P & $\begin{array}{c}\text { Espectrofotômetro UV- } \\
1800 \text { - SHIMADZU }\end{array}$ \\
\hline DUREZA & $\mathrm{mg} \mathrm{CaCO}{ }_{3} / \mathrm{L}^{-1}$ & SM 2340 B & $\begin{array}{l}\text { Cromatógrafo Iônico } 761 \text { - } \\
\text { Compact IC - METROHM }\end{array}$ \\
\hline ÍONS & $\mathrm{mg} / \mathrm{L}^{-1}$ & SM 4110 & $\begin{array}{l}\text { Cromatógrafo Iônico } 761 \text { - } \\
\text { Compact IC - METROHM }\end{array}$ \\
\hline
\end{tabular}

\subsection{Tratamento dos dados de qualidade da água}

Após a devida organização dos dados foram feitas tabelas diferenciadas para melhor visualização, interpretação e análise dos dados, a partir dos métodos estatísticos com objetivo de gerar informações sistematizadas da qualidade da água subterrânea da BEARJ.

Assim, há uma tabela para cada mês com todos os parâmetros analisados; uma tabela resumida por parâmetro; poço; estação chuvosa; estação seca e uma somente com os poços que tiveram sua coleta em todos os 12 meses.

Após a observação dos dados, a variável que possuía valor abaixo do limite de detecção $(<\mathrm{LD})$ foi substituída pelo valor da metade do LD da mesma variável. Já os valores nulos (zero) foram substituídos pela metade do menor valor da série para aquela variável, no mesmo ponto (ZENG E RASMUSSEN, 2005; MOURA, 2008; MUNIZ, 2014). 
Nesta pesquisa, se optou por excluir as variáveis de qualidade que apresentaram valores nulos ou abaixo do limite de detecção (dados censurados) em mais de $85 \%$ do período analisado - de julho/2014 a junho/2015 conformo descrito por Reimman et al. (2008) e Sabino et al. (2014).

Desta forma, 6 variáveis analisadas foram censuradas: salinidade, lítio, amônio, nitrito, brometo, fosfato. Deste modo, foram analisadas estatisticamente 15 variáveis, sendo elas: condutividade, SDT, pH, fósforo, alcalinidade, bicarbonato, dureza, sódio, potássio, cálcio, magnésio, fluoreto, cloreto, nitrato e sulfato.

Também se optou por excluir os poços que apresentavam menos de $50 \%$ da série completa, ou seja, 6 das 12 coletas realizadas para cada poço (REIMMAN et al.,2008). Portanto, foram excluídos 7 poços, intitulados de 38, 44, 49, 72, 84, 85 e 89. Assim, foram analisados 38 poços.

\subsection{Delimitação da área de drenagem}

A Lei Federal 9433/ 1997 estabelece, em seu capítulo primeiro, a bacia hidrográfica como sendo a unidade territorial para implementação da Política Nacional de Recursos Hídricos, assim como a atuação do Sistema Nacional de Gerenciamento de Recursos Hídricos (BRASIL, 1997).

A padronização e automatização do traçado de bacias hidrográficas são fundamentais para a efetivação adequada da PNRH, evitando-se possíveis conflitos de utilização dos recursos hídricos (SOBRINHO et al., 2010).

Desta maneira, diversos estudos ambientais necessitam da análise das características morfométricas das bacias hidrográficas, pois estas influenciam no ciclo hidrológico (infiltração, evapotranspiração, escoamento superficial e subsuperficial) (OLIVEIRA et al., 2010).

Para a obtenção destas bacias utiliza-se como dado principal o modelo digital de terreno (MDT) ou de elevação (MDE). Deste modo, os MDTs ou MDE podem ser utilizados no delineamento de redes de drenagem, limites de bacias hidrográficas, cálculo de declividade, altitude, verificação do fluxo do escoamento superficial e nos modelos hidrológicos (VALERIANO, 2003; RIBEIRO et al., 2008). 
O MDT da área de estudo foi gerado a partir da interpolação dos dados altimetricos (altimetria linear e altimetria pontual) e hidrografia na escala 1:10.000 do Sistema Cartográfico do Distrito Federal - SICAD/DF, a partir da ferramenta Topo to Raster do ArcGis, com resolução espacial de 2 metros.

Posteriormente, foi iniciada a delimitação automática das áreas de drenagem de cada poço. Para isso foi instalado no ArcGis o TauDEM (Terrain Analysis Using Digital Elevation Models), desenvolvido por Tarboton (2002) e instituições cooperadas, que é um conjunto de ferramentas para construção de análises hidrológicas com base no Modelo Digital de Elevação (MDE).

Nele, várias etapas são realizadas e produtos são gerados:

PIT REMOVE - Desenvolvimento de Modelos Digitais de Elevação hidrologicamente corretos (remoção de depressões);

1) FLOW DIRECTIONS - Calcula o caminho de fluxo (direções) e a declividade;

2) D8 CONTRIBUTING AREA - Calcula a área de contribuição usando métodos de direção de fluxo simples;

3) STREAM DEFINITION BY THRESHOLD - Delimitação das redes de drenagem;

4) GAGE WATERSHED - Delimitação de bacias hidrográficas e sub-bacias.

O processamento pelo TauDEM ocorre da seguinte maneira: o raster de entrada é o MDE, após executa se o pit remove; flow directions; $d 8$ contributing area; stream definition by threshold; em seguida é executado novamente o d8 contributing area, juntamente com o (s) ponto (s) criado (s) no local do exutório ou ponto que se quer obter a área de contribuição; e o stream definition by threshold. O último passo é a geração da bacia com a ferramenta gage watershed.

\subsection{Vetorização e classificação do uso e ocupação da terra}

O desenvolvimento da sociedade deixam mudanças na terra, e a análise de tal processo é possível devido à interpretação de produtos de sensoriamento remoto; no qual dispõe conhecimentos de uso e ocupação da terra. Sendo assim, auxiliam na visualização e identificação dos elementos exibidos, que serão sintetizados por meio dos mapas (LEITE E ROSA, 2012). 
Assim, para o incremento deste estudo foi realizado o mapeamento de uso e ocupação da terra da bacia hidrográfica do Alto Rio Jardim. A vetorização dos polígonos de tipos de uso da terra baseou-se na ortofoto do Distrito Federal, disponibilizada pela Terracap referente ao ano de 2014.

Assim, através da análise interpretativa da imagem; de informações obtidas do campo, onde ao longo das doze (12) campanhas foi realizado o registro fotográfico e escrito do uso da terra acerca dos poços coletados e; do mapa de uso e cobertura do solo para o ano de 2008 de Chaves (2011); foram determinadas nove (9) classes temáticas do uso e ocupação da terra: agricultura, área construída, campo cerrado, cerradão, corpo d'água, mata de galeria, pastagem, pivô central e solo exposto.

Analisando preliminarmente alguns resultados feitos no software estatístico, observou-se que seria viável e melhor para as análises estatísticas agrupar as classes de uso campo cerrado, cerradão e mata de galeria; transformando-as em área natural. $\mathrm{O}$ uso pivô central possui área pouco representativa, em relação à abordagem estatística, assim foi decido realocá-lo para o uso agricultura.

\subsection{Análise estatística dos dados}

\subsubsection{Estatística Descritiva}

Os dados gerados e compilados foram analisados estatisticamente, a fim de se gerar informações consistentes que atendam aos objetivos propostos neste trabalho.

Primeiramente, a estatística descritiva foi realizada a fim de gerar uma análise preliminar de como os dados se apresentam e foram utilizados os cálculos da média (MÉDIA), mínimo (MÍNIMO), máximo (MÁXIMO), desvio padrão (DP) e coeficiente de variação $(\mathrm{CV})$.

Também foi realizada uma análise para inferir se os dados medidos dos 38 poços ao longo dos 12 meses de coleta estavam dentro dos padrões estabelecidos para Classe $1 \mathrm{e}$ 2 de água subterrânea, de acordo com a legislação CONAMA nº 396 de 2008.

\subsubsection{Regressão Quadrática Múltipla}

A partir dos dados levantados em 38 poços, ao longo de 12 meses (julho/2014 a junho/2015) obtidos no presente estudo, foi criada uma matriz de dados com 62 variáveis avaliadas (propriedades físicas e químicas dos solos e declividade do terreno). 
O presente estudo tem o propósito de investigar e modelar a relação das variáveis: condutividade, SDT, pH, fósforo, alcalinidade, bicarbonato, dureza, sódio, cálcio, magnésio, cloreto, potássio, fluoreto, nitrato e sulfato ( $\mathrm{Y}$ = variáveis dependentes) entre as variáveis independentes estudadas (cambissolo, gleissolo, latossolo amarelo, latossolo vermelho, latossolo vermelho - amarelo, neossolo quartzarênico, plintossolo, uso agricultura, uso pastagem, uso área construída, uso solo exposto, uso área natural, uso corpo d'agua, nível, área de contribuição e declividade), utilizando a análise de regressão linear múltipla. Foram testadas as possibilidades de geração de um modelo de regressão para cada mês analisado, logo, um total de 12 modelos por variável dependente.

O modelo é chamado de regressão linear múltipla, pois envolve mais de um coeficiente de regressão. Neste estudo será ajustado um modelo chamado de regressão polinomial múltipla de segunda ordem também chamado de regressão quadrática múltipla. Os modelos de regressão polinomial são casos especiais do modelo de regressão linear múltipla geral, assim, todos os pressupostos e resultados para o ajuste deste tipo de modelo, inclusive, para a inferência estatística são válidos da mesma forma.

As variáveis independentes utilizadas para a construção do modelo foram selecionadas pelo método backward. Este tipo de modelo contém componentes lineares e quadráticos. Desta forma obteve-se a Eq. 4.

$$
\mathrm{Y}_{\mathrm{i}}=\beta_{0}+\beta_{1} \mathrm{x}_{\mathrm{i} 1}+\beta_{11} \mathrm{x}_{\mathrm{i} 1}^{2}+\beta_{2} \mathrm{x}_{\mathrm{i} 2}+\beta_{22} \mathrm{x}_{\mathrm{i} 2}^{2}+\ldots+\beta_{\mathrm{k}} \mathrm{x}_{\mathrm{ik}}+\beta_{\mathrm{k} 2} \mathrm{x}_{\mathrm{ik}}^{2}+\varepsilon_{i}
$$

onde $\mathrm{i}=1, \ldots, \mathrm{n} ; \mathrm{n}=$ número de indivíduos; $\mathrm{Y}_{\mathrm{i}}=$ observação da variável dependente para o i-ésimo indivíduo; $x_{\mathrm{i}}=\left(x_{\mathrm{i} 1}, x_{\mathrm{i} 2}, \ldots, x_{\mathrm{ik}}\right)=$ vetor de observações das variáveis independentes para o i-ésimo indivíduo; $x_{\mathrm{i}}^{2}=\left(x^{2}{ }_{\mathrm{i} 1}, x_{\mathrm{i} 2}^{2}, \ldots, x_{\mathrm{ik}}^{2}\right)=$ vetor de observações ao quadrado das variáveis independentes para o i-ésimo indivíduo; $\beta=\left(\beta_{0}\right.$, $\beta_{1}, \beta_{2}, \ldots, \beta_{\mathrm{k}}$ ) = vetor de coeficientes de regressão, sendo $\beta_{0}=$ coeficiente linear e $\beta_{1}, \beta_{2}$, ..., $\beta_{\mathrm{k}}=$ coeficientes angulares; e $\varepsilon_{\mathrm{i}}=$ componente de erro aleatório. Assume-se que esses erros são independentes e seguem distribuição normal com média zero e variância desconhecida $\sigma^{2}$. 
A homocedasticidade (variância dos resíduos constante) e a independência dos resíduos foram verificadas através da análise dos gráficos dos resíduos. Esses pressupostos são muito relevantes para a estimação dos modelos, pois a falta dos mesmos faz com que na estimativa dos coeficientes pelo método dos mínimos quadrados não gerem estimativas de parâmetros eficientes ou de variância mínima, o que implica em erros-padrões viesados e incorreção dos testes F (Fisher) e t (Student) e dos intervalos de confiança.

A suposição de normalidade dos resíduos foi verificada a partir de gráficos de probabilidade normal dos resíduos, também chamados gráficos quantil-quantil Q-Q plots. Nestes gráficos especiais o quantil amostral versus o quantil esperado sob normalidade, podem ser usados para validar tal pressuposto.

A análise de variância (ANOVA) foi utilizada para avaliação do modelo de regressão linear múltipla pelo método dos mínimos quadrados, e a variação total dos valores de Y, em torno de sua média amostral, pode ser decomposta em duas partes. A primeira é a variação dos valores estimados em torno de sua média e representa a variação explicada pelo modelo, calculada pela soma dos quadrados do modelo $\left(\mathrm{SS}_{\mathrm{M}}\right)$. A segunda componente é o resíduo, ou seja, a variação não explicada pelo modelo, calculada pela soma dos quadrados dos resíduos ou erros $\left(\mathrm{SS}_{\mathrm{R}}\right)$.

O estudo dessas duas componentes constitui a base do tratamento da análise de variância (Bussab, 1986), além de testar as hipóteses $\mathrm{H}_{0}$ e $\mathrm{H}_{1}$ pelo teste $\mathrm{F}$ ao nível de significância de $5 \%$. A hipótese $\mathrm{H}_{0}$ corresponde a: $\beta_{1}=\beta_{2}=\ldots=\beta_{\mathrm{k}}=0$ (não existe nenhuma relação linear entre a variável dependente e as variáveis independentes). A hipótese $\mathrm{H}_{1}$ corresponde a pelo menos um $\beta_{\mathrm{j}} \neq 0, \mathrm{j}=1,2, \ldots$, $\mathrm{k}$ (existe uma relação linear entre a variável dependente ( $\mathrm{Y}=$ produtividade) em pelo menos uma das variáveis independentes).

Utilizou-se o coeficiente da determinação $\mathrm{R}^{2}$ para medir a proporção da variação de Y que é explicada pelo conjunto das variáveis independentes e $\mathrm{R}^{2}$ ajustado que informa o quanto da variância de $\mathrm{Y}$ pode ser creditada ao modelo se ele tiver sido derivado da população de onde a amostra foi retirada. Trata-se de medidas descritivas de qualidade do ajustamento do modelo obtido.

O teste t avaliou a significância estatística dos coeficientes de regressão estimados para as variáveis independentes ao nível de significância de 5\%. A hipótese nula e a 
hipótese alternativa são: $\mathrm{H}_{0}: \beta_{1}=\beta_{2}=\ldots=\beta_{\mathrm{k}}=0$ (não existe uma relação linear significativa entre as variáveis independentes na contribuição da variável dependente), $\mathrm{H}_{1}: \beta_{\mathrm{j}} \neq 0, \mathrm{j}=1,2, \ldots, \mathrm{k}$ (existe uma relação linear significativa entre as variáveis independentes na contribuição da variável dependente).

A análise de multicolinearidade foi avaliada no modelo de regressão e refere-se à correlação entre duas ou mais variáveis independentes ou entre uma delas e as demais incluídas no modelo, pelo fator de inflação da variância (Mayers, 2000).

Em resumo, foram avaliados os quatro pressupostos para regressão (a linearidade, a independência dos erros, a normalidade dos erros e a igualdade de variâncias) para verificar a existência de comportamento linear entre as variáveis, a existência de homocedasticidade nos dados, se os resíduos têm distribuição normal e se há multicolinearidade das variáveis.

Todos os procedimentos foram realizados com a utilização do software Statistical Package for Social Sciences (SPSS 19.0). 


\section{RESULTADOS E DISCUSSÃO}

\subsection{Mapas de Delimitação e Classificação}

$\mathrm{Na}$ Figura 13 é apresentado o mapa resultante da delimitação das bacias de drenagem de cada poço analisado. Nota-se que as bacias possuem um tamanho médio de 49,10 hectares, sendo que o poço 1 abrange a maior área de drenagem com 158,73 ha e poço 5 com a menor, 1,24 ha.

O tamanho das áreas de drenagens foi utilizado como uma das variáveis na regressão quadrática múltipla e também para a confecção dos mapas apresentados nas Figuras 15 e 16, de uso e ocupação da terra e solo, respectivamente.

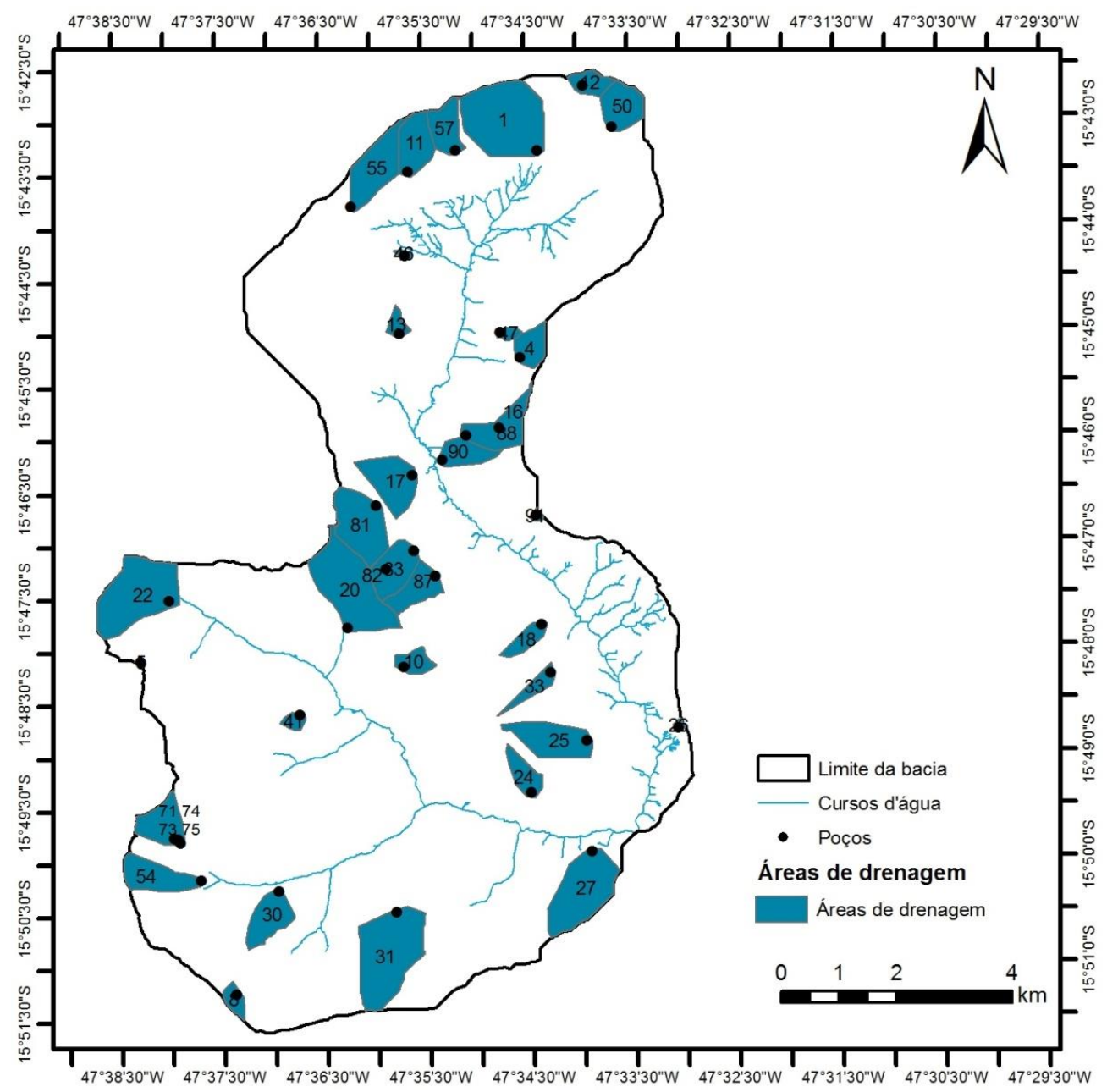

Figura 13 - Mapa das áreas de drenagem da Bacia Experimental do Alto Rio Jardim.

O mapa de uso e ocupação da terra apresenta-se na Figura 14, e na Tabela 2 estão estruturadas as áreas em hectare das respectivas classes de uso, evidenciando que a 
bacia possui área predominantemente agrícola, com 6.741,83 hectares, ou seja, 64,10\% referente a esse uso, que está distribuído por toda a bacia. Os outros usos mais expressivos foram pastagem e campo cerrado, com aproximadamente $12 \%$ em cada classe.

Os resultados corroboram dados da Emater (2009) no que diz respeito ao tipo de ocupação presente na bacia, que é majoritariamente ocupada pela agricultura. Sendo as propriedades agrícolas as responsáveis pela produção da maior parte de grãos (milho, soja, trigo e feijão) do DF, de parte das hortaliças e das frutas, de carne bovina e de aves (EMATER, 2009).

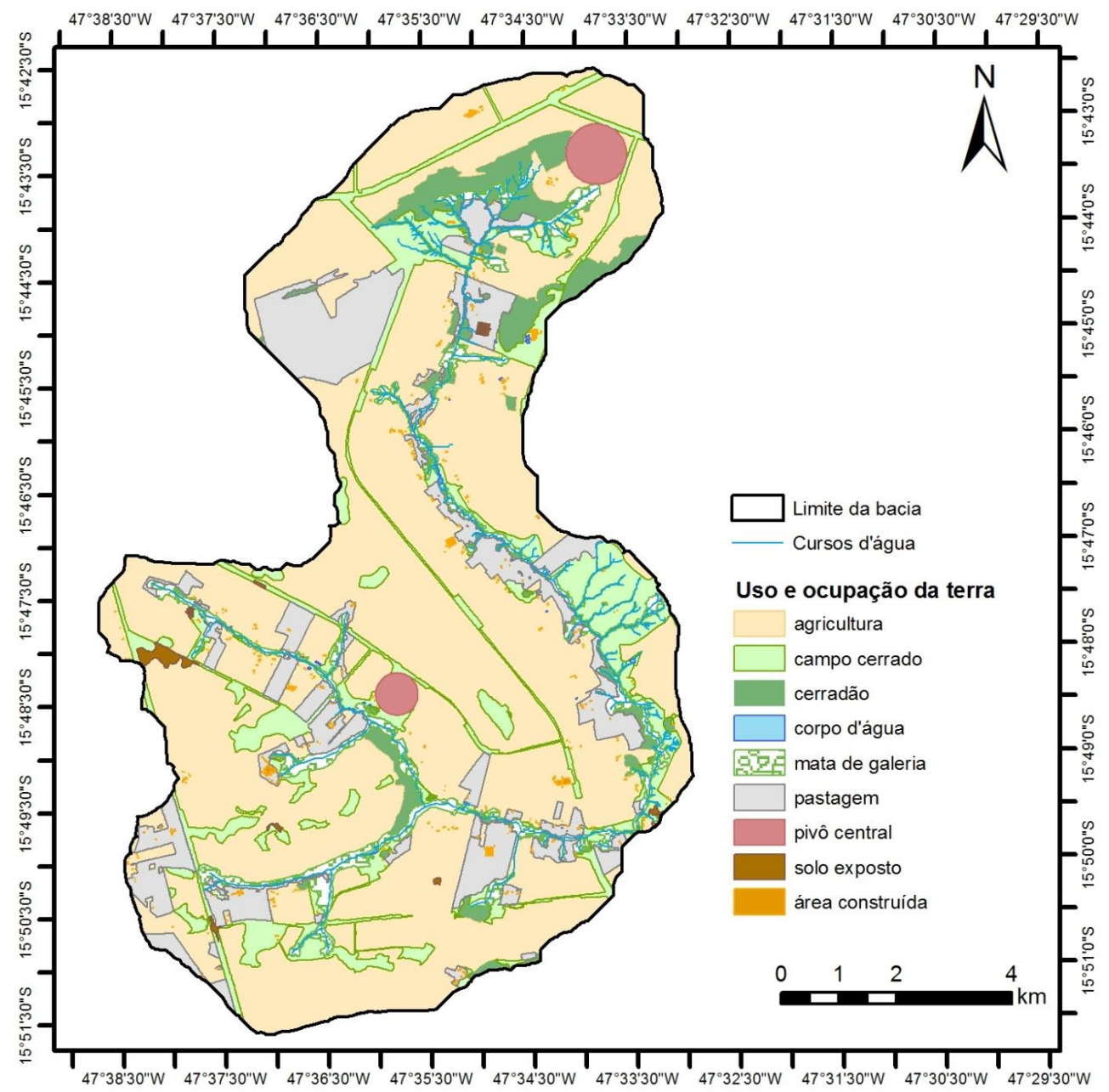

Figura 14 - Mapa de uso e ocupação da terra da Bacia Experimental do Alto Rio Jardim. 
Tabela 2 - Área em hectare (ha) das classes de uso e ocupação da terra na Bacia Experimental do Alto Rio Jardim.

\begin{tabular}{ccc}
\hline Classes de uso & Área (ha) & $\%$ \\
\hline Agricultura & $6.741,83$ & 64,10 \\
\hline Pastagem & $1.292,76$ & 12,29 \\
Campo cerrado & $1.261,28$ & 11,99 \\
\hline Mata de galeria & 558,45 & 5,31 \\
\hline Cerradão & 471,37 & 4,48 \\
\hline Pivô central & 128,78 & 1,22 \\
\hline Solo exposto & 31,85 & 0,30 \\
\hline Área construída & 21,25 & 0,20 \\
\hline Corpo d'água & 9,98 & 0,09 \\
\hline Total & $10.512,55$ & 100,0 \\
\hline
\end{tabular}

A partir do mapa das áreas de drenagem (Figura 13) e do mapa de uso e ocupação da terra (Figura 14) foi confeccionado o mapa de uso somente das áreas de drenagem de cada poço estudado (Figura 15 e Tabela 3). O mesmo processo foi realizado com mapa de solo apresentado na Figura 4 resultando na Figura 16 e Tabela 4.

As classes de uso e ocupação mais expressivos das áreas de drenagem é o uso agrícola com 80,09 \%, campo cerrado com 12,06 \% e pastagem com 5,39\%. Assim, corrobora-se o fato das áreas de drenagem serem representativas da Bacia do Alto Rio Jardim, onde também são predominantemente áreas agrícolas. 


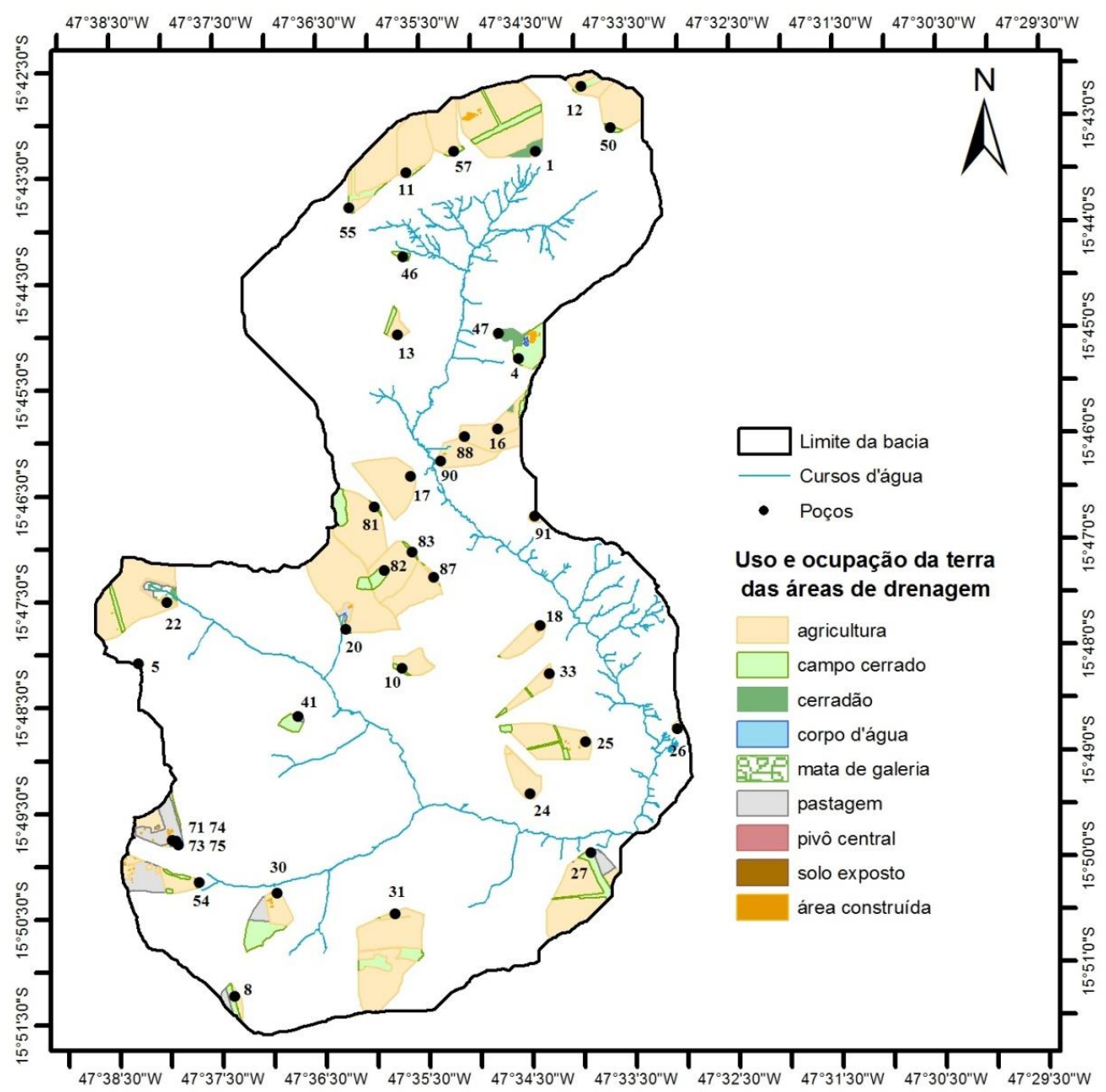

Figura 15 - Mapa de uso e ocupação da terra das áreas de drenagem inseridas na Bacia Experimental do Alto Rio Jardim.

Tabela 3 - Área em hectare (ha) das classes de uso e ocupação da terra das áreas de drenagem da Bacia Experimental do Alto Rio Jardim.

\begin{tabular}{ccc}
\hline Classes de uso & Área (ha) & Área (\%) \\
\hline Agricultura & 1377,69 & 80,09 \\
Campo cerrado & 207,46 & 12,06 \\
Pastagem & 92,81 & 5,40 \\
Cerradão & 23,63 & 1,37 \\
Mata de galeria & 13,55 & 0,79 \\
Área construída & 3,48 & 0,20 \\
Solo exposto & 0,83 & 0,05 \\
Corpo d'água & 0,79 & 0,05 \\
Pivô central & 0,02 & 0,00 \\
Total & 1720,26 & 100,00 \\
\hline
\end{tabular}

A Figura 16 e Tabela 4 se referem ao mapa do solo das áreas de drenagem, onde o latossolo vermelho representa 54,35\%, latossolo vermelho-amarelo possui $28,28 \%$ da 
área e cambissolo $12,97 \%$ das áreas. Sendo novamente representativas da Bacia Experimental do Alto Rio Jardim, pois Lima et al., (2007) evidenciaram que a bacia é predominantemente composta por Latossolos (76,38\%), seguido de Cambissolos $(16,68 \%)$.

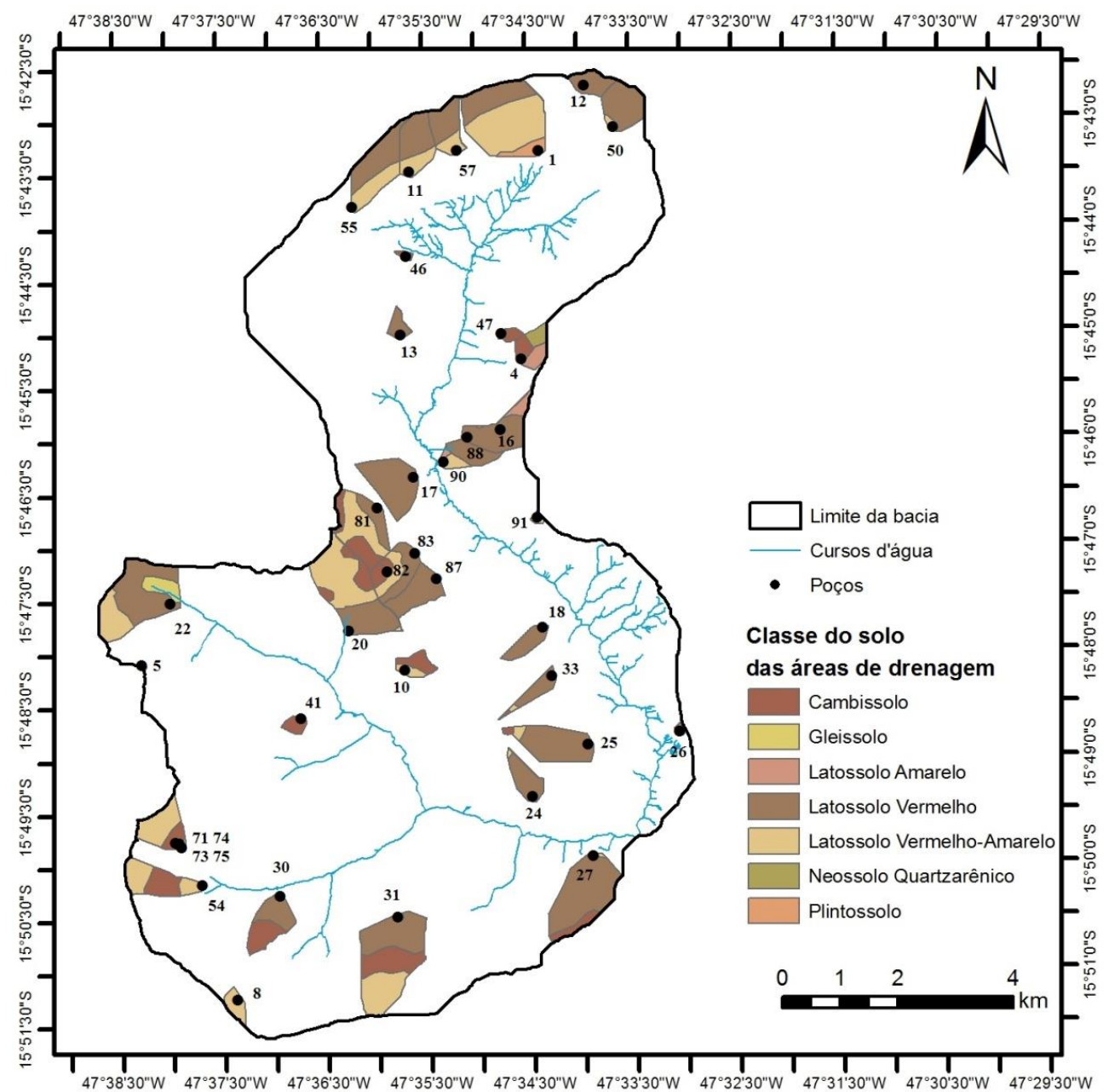

Figura 16 - Mapa da classe do solo das áreas de drenagem inseridas na Bacia Experimental do Alto Rio Jardim.

Tabela 4 - Área em hectare (ha) das classes de solo das áreas de drenagem da Bacia Experimental do Alto Rio Jardim.

\begin{tabular}{ccc}
\hline Classes de solo & Área (ha) & Área (\%) \\
\hline Latossolo Vermelho & 934,96 & 54,35 \\
Latossolo Vermelho-Amarelo & 486,52 & 28,28 \\
Cambissolo & 223,18 & 12,97 \\
Latossolo Amarelo & 32,13 & 1,87 \\
Gleissolo & 19,65 & 1,14 \\
Plintossolo & 13,92 & 0,81 \\
Neossolo Quartzarênico & 9,82 & 0,57 \\
Total & 1720,18 & 100,00 \\
\hline
\end{tabular}




\subsection{Análise da estatística descritiva: Valores Médios, Desvio-Padrão e Coeficiente de Variação.}

As Tabelas 5, 6, 7 e 8 apresentam os valores médios, os desvios-padrão e os coeficientes de variação para as 15 variáveis analisadas, dos 38 poços, ao longo das doze campanhas amostrais, julho de 2014 a junho de 2015.

O CV é uma medida relativa de dispersão, útil para comparar termos relativos do grau de concentração em torno da média, ou seja, é o desvio-padrão expresso em porcentagem da média, sendo utilizado neste estudo devido à capacidade de comparação de distribuições diferentes. E tal medida é representada pela Eq. 5.

$$
\mathrm{CV}=\frac{\text { desvio padrão }}{\text { média }} \cdot 100
$$

onde CV: coeficiente de variação.

O resultado do CV é classificado segundo Pimentel Gomes (1985) como: menor ou igual a 10\% - baixa dispersão; entre 10 e $20 \%$ - média dispersão; entre 20 e $30 \%$ - alta dispersão e maior que $30 \%$ - muito alta.

Tabela 5 - Média, Desvio-Padrão e Coeficientes de Variação para CE, SDT, pH e P.

\begin{tabular}{cccccccccccccc}
\hline & & CE & & \multicolumn{3}{c}{ SDT } & \multicolumn{3}{c}{ PH } & & \multicolumn{3}{c}{ P } \\
\hline MÊS & MÉDIA & DP & CV & MÉDIA & DP & CV & MÉDIA & DP & CV & MÉDIA & DP & CV \\
\hline JUL & 13.23 & 14.84 & 112.22 & 5.80 & 7.11 & 122.58 & 6.14 & 0.25 & 3.99 & 0.09 & 0.27 & 310.64 \\
\hline AGO & 11.41 & 11.90 & 104.26 & 4.92 & 5.70 & 115.66 & 5.88 & 0.37 & 6.37 & 0.05 & 0.18 & 386.55 \\
\hline SET & 11.58 & 15.68 & 135.36 & 5.02 & 7.52 & 149.83 & 6.27 & 0.38 & 6.04 & 0.07 & 0.26 & 358.84 \\
\hline OUT & 21.10 & 38.54 & 182.66 & 9.59 & 18.53 & 193.19 & 6.14 & 0.29 & 4.67 & 0.05 & 0.20 & 375.41 \\
\hline NOV & 29.39 & 77.72 & 264.46 & 13.62 & 37.65 & 276.37 & 6.05 & 0.38 & 6.33 & 0.05 & 0.17 & 361.56 \\
\hline DEZ & 14.03 & 17.35 & 123.67 & 6.17 & 8.24 & 133.56 & 6.26 & 0.27 & 4.31 & 0.01 & 0.01 & 140.45 \\
\hline JAN & 17.43 & 21.38 & 122.62 & 7.82 & 10.25 & 130.98 & 6.00 & 0.30 & 4.93 & 0.01 & 0.01 & 131.23 \\
\hline FEV & 15.25 & 19.38 & 127.08 & 6.78 & 9.29 & 137.10 & 5.88 & 0.34 & 5.73 & 0.02 & 0.03 & 153.52 \\
\hline MAR & 16.34 & 25.48 & 155.91 & 7.31 & 12.22 & 167.32 & 5.88 & 0.35 & 5.91 & 0.02 & 0.05 & 214.71 \\
\hline ABR & 25.37 & 52.80 & 208.17 & 11.64 & 25.44 & 218.57 & 5.84 & 0.39 & 6.70 & 0.02 & 0.06 & 250.12 \\
\hline MAI & 25.50 & 39.64 & 155.44 & 11.70 & 19.06 & 162.92 & 5.85 & 0.36 & 6.21 & 0.04 & 0.10 & 240.75 \\
\hline JUN & 22.71 & 30.47 & 134.14 & 10.35 & 14.62 & 141.25 & 5.87 & 0.38 & 6.46 & 0.05 & 0.12 & 249.22 \\
\hline
\end{tabular}

Legenda: CE - Condutividade elétrica; SDT - Sólidos Dissolvidos Totais; P - Fósforo. 
Tabela 6 - Média, Desvio-Padrão e Coeficientes de Variação para ALC, BIC, DUR e Na+.

\begin{tabular}{cccccccccccccc}
\hline & & ALC & & & \multicolumn{3}{c}{ BIC } & & & DUR & & \multicolumn{3}{c}{ Na $^{+}$} \\
\hline MÊS & MÉDIA & DP & CV & MÉDIA & DP & CV & MÉDIA & DP & CV & MÉDIA & DP & CV \\
JUL & 7.22 & 10.28 & 142.41 & 1.60 & 2.15 & 134.22 & 8.96 & 7.71 & 86.07 & 0.91 & 1.30 & 142.23 \\
\hline AGO & 5.53 & 7.51 & 135.71 & 1.28 & 1.59 & 123.66 & 4.91 & 5.94 & 120.99 & 0.89 & 1.10 & 122.58 \\
\hline SET & 6.43 & 8.71 & 135.55 & 1.36 & 1.68 & 123.17 & 6.04 & 4.32 & 71.43 & 0.72 & 0.96 & 133.68 \\
\hline OUT & 7.64 & 13.77 & 180.23 & 1.67 & 2.74 & 163.82 & 4.41 & 3.86 & 87.38 & 0.90 & 1.06 & 117.16 \\
\hline NOV & 6.91 & 13.73 & 198.81 & 1.45 & 2.50 & 172.21 & 10.54 & 8.54 & 81.01 & 1.20 & 1.32 & 109.97 \\
\hline DEZ & 4.09 & 5.35 & 130.73 & 0.89 & 1.08 & 121.36 & 9.65 & 6.43 & 66.65 & 0.70 & 0.65 & 92.80 \\
\hline JAN & 5.15 & 5.94 & 115.21 & 1.21 & 1.33 & 110.03 & 10.47 & 8.03 & 76.68 & 0.82 & 0.53 & 64.89 \\
\hline FEV & 4.06 & 6.73 & 165.97 & 0.92 & 1.34 & 145.67 & 10.60 & 8.88 & 83.78 & 0.70 & 0.54 & 77.49 \\
\hline MAR & 5.51 & 10.10 & 183.32 & 1.27 & 2.21 & 173.44 & 9.50 & 7.96 & 83.71 & 0.70 & 0.62 & 88.65 \\
\hline ABR & 7.92 & 12.89 & 162.79 & 1.81 & 2.75 & 151.77 & 12.95 & 12.43 & 96.04 & 0.93 & 0.73 & 78.97 \\
\hline MAI & 7.82 & 9.98 & 127.61 & 1.81 & 2.12 & 117.16 & 13.74 & 8.90 & 64.73 & 1.31 & 1.95 & 148.48 \\
\hline JUN & 8.96 & 9.66 & 107.82 & 2.13 & 2.13 & 100.14 & 14.62 & 10.35 & 70.84 & 0.94 & 1.10 & 116.73 \\
\hline
\end{tabular}
Legenda: ALC - Alcalinidade; BIC - Bicarbonato; DUR - Dureza; $\mathrm{Na}^{+}$- Sódio.

Tabela 7 - Média, Desvio-Padrão e Coeficientes de Variação para $\mathrm{K}^{+}, \mathrm{Ca}^{2+}, \mathrm{Mg}^{2+} \mathrm{e} \mathrm{F}^{-}$.

\begin{tabular}{cccccccccccccc}
\hline & & \multicolumn{1}{c}{$\mathbf{K}^{+}$} & \multicolumn{3}{c}{$\mathrm{Ca}^{2+}$} & \multicolumn{3}{c}{$\mathbf{M g}^{2+}$} & \multicolumn{3}{c}{$\mathbf{F}^{-}$} \\
\hline MÊS & MÉDIA & DP & CV & MÉDIA & DP & CV & MÉDIA & DP & CV & MÉDIA & DP & CV \\
\hline JUL & 0.40 & 0.68 & 170.69 & 2.86 & 2.45 & 85.68 & 0.44 & 0.65 & 148.25 & 0.02 & 0.06 & 381.31 \\
\hline AGO & 0.39 & 0.42 & 106.16 & 1.27 & 1.77 & 138.81 & 0.42 & 0.63 & 149.58 & 0.02 & 0.06 & 355.99 \\
\hline SET & 0.36 & 0.56 & 152.78 & 1.76 & 1.20 & 68.08 & 0.40 & 0.55 & 137.80 & 0.02 & 0.06 & 356.97 \\
\hline OUT & 0.44 & 0.67 & 152.70 & 1.03 & 0.75 & 73.34 & 0.45 & 0.61 & 136.98 & 0.02 & 0.05 & 243.37 \\
\hline NOV & 0.77 & 1.74 & 227.33 & 3.03 & 2.35 & 77.43 & 0.72 & 0.92 & 128.07 & 0.02 & 0.05 & 261.09 \\
\hline DEZ & 0.43 & 1.15 & 269.78 & 2.95 & 1.98 & 66.97 & 0.55 & 0.56 & 101.05 & 0.01 & 0.03 & 213.35 \\
\hline JAN & 0.74 & 1.36 & 183.67 & 3.22 & 2.21 & 68.80 & 0.59 & 0.71 & 119.79 & 0.05 & 0.06 & 113.09 \\
\hline FEV & 0.58 & 1.46 & 250.16 & 3.31 & 2.92 & 88.39 & 0.57 & 0.58 & 101.93 & 0.02 & 0.04 & 202.02 \\
\hline MAR & 0.51 & 1.16 & 229.27 & 2.86 & 2.27 & 79.33 & 0.57 & 0.74 & 128.95 & 0.03 & 0.05 & 161.79 \\
\hline ABR & 1.12 & 3.76 & 334.74 & 3.84 & 3.26 & 84.88 & 0.82 & 1.22 & 149.60 & 0.02 & 0.05 & 215.44 \\
\hline MAI & 0.56 & 0.95 & 170.79 & 4.04 & 2.59 & 64.09 & 0.89 & 1.15 & 129.65 & 0.03 & 0.06 & 190.07 \\
\hline JUN & 0.71 & 2.14 & 298.89 & 4.76 & 3.27 & 68.73 & 0.66 & 0.84 & 125.78 & 0.08 & 0.08 & 111.94 \\
\hline
\end{tabular}

Legenda: $\mathrm{K}^{+}$- Potássio; $\mathrm{Ca}^{2+}$ - Cálcio; $\mathrm{Mg}^{2+}$ - Magnésio; $\mathrm{F}^{-}$- Fluoreto.

Tabela 8 - Média, Desvio-Padrão e Coeficientes de Variação para $\mathrm{Cl}^{-}, \mathrm{NO}_{3}{ }^{-}$e $\mathrm{SO}_{4}{ }^{2-}$.

\begin{tabular}{cccccccccc}
\hline & \multicolumn{3}{c}{$\mathrm{Cl}^{-}$} & \multicolumn{3}{c}{ NO $^{-}$} & \multicolumn{3}{c}{ SO $_{4}{ }^{2-}$} \\
\hline MÊS & MÉDIA & DP & CV & MÉDIA & DP & CV & MÉDIA & DP & CV \\
JUL & 0.24 & 0.17 & 70.37 & 0.16 & 0.26 & 161.02 & 0.10 & 0.15 & 144.39 \\
AGO & 0.31 & 0.20 & 64.81 & 0.17 & 0.24 & 138.14 & 0.04 & 0.15 & 349.00 \\
\hline SET & 0.46 & 0.64 & 139.49 & 0.30 & 0.54 & 182.24 & 0.15 & 0.59 & 386.89 \\
OUT & 0.63 & 0.67 & 106.60 & 0.28 & 0.41 & 147.04 & 0.05 & 0.09 & 181.50 \\
NOV & 0.79 & 1.42 & 180.58 & 0.39 & 1.01 & 258.31 & 0.09 & 0.26 & 300.62 \\
DEZ & 0.39 & 0.74 & 188.35 & 0.50 & 1.82 & 363.51 & 0.13 & 0.48 & 367.90 \\
JAN & 0.58 & 0.52 & 89.31 & 0.51 & 1.38 & 269.45 & 0.50 & 1.25 & 252.52 \\
\hline
\end{tabular}




\begin{tabular}{cccccccccc}
\hline FEV & 0.41 & 0.43 & 104.44 & 0.49 & 1.68 & 340.97 & 0.12 & 0.49 & 419.78 \\
MAR & 0.38 & 0.44 & 116.46 & 0.38 & 0.85 & 225.88 & 0.07 & 0.22 & 331.21 \\
ABR & 0.81 & 1.62 & 198.52 & 1.61 & 7.58 & 469.88 & 0.28 & 1.14 & 401.80 \\
MAI & 0.87 & 1.68 & 193.75 & 1.59 & 6.70 & 421.99 & 0.30 & 0.83 & 280.05 \\
JUN & 0.76 & 1.25 & 165.44 & 1.12 & 4.00 & 356.90 & 0.20 & 0.64 & 315.63 \\
\hline
\end{tabular}

Legenda: $\mathrm{Cl}^{-}$- Cloreto; $\mathrm{NO}_{3}{ }^{-}$- Nitrato; $\mathrm{SO}_{4}{ }^{2-}$ - Sulfato.

Os diferentes valores dos desvios padrões, quando associados aos valores médios de CV das variáveis em estudo, trazem como resultado diferentes amplitudes ou limites de classe, determinando assim classificações distintas do CV para cada variável.

Como pode se observar, nas Tabelas de 5 a 8 e na Figura 17, no mês de abril a variável nitrato obteve o CV mais elevado, atingindo assim 469,88\%, demonstrando ter os valores mais heterogêneos neste mês. Já em fevereiro, o sulfato obteve seu pico com CV igual a 419,78\%. Nos cinco primeiros meses da pesquisa o CV do fósforo solúvel e do fluoreto foi mais elevado. Sendo que a maioria das variáveis obteve o CV entre 60 e $200 \%$. Os menores valores do CV foram do $\mathrm{pH}$ onde a concentração média nos poços foi em torno de 5,84 e 6,27, realmente, não variando muito.

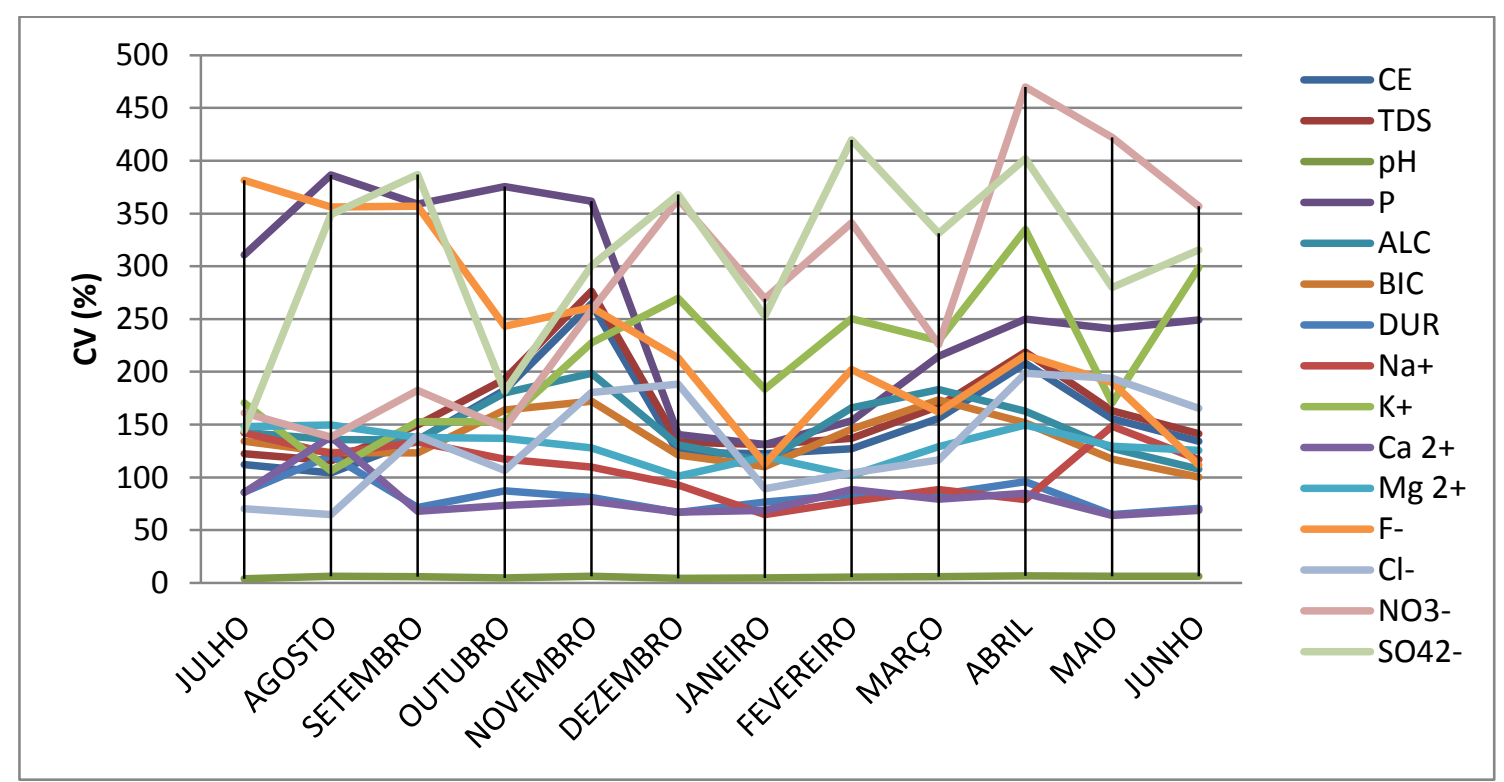

Figura 17 - Coeficiente de Variação das variáveis analisadas durante um ano hidrológico.

Desta forma, o coeficiente de variação do $\mathrm{pH}$ foi menor que $10 \%$ indicando que há homogeneidade entre os valores encontrados nos 38 poços durante as doze coletas. As demais variáveis apresentaram o CV maior que 30\%, ou seja, a variabilidade em relação à média foi bastante alta, tornando os valores mensais encontrados heterogêneos, para todos os poços ao longo da série amostral. 


\subsection{Valores de Referência}

Os valores de referência utilizados se referem aos valores máximos permitidos dos parâmetros de qualidade da água subterrânea, expressos pela resolução CONAMA 396/2008 para Classe 1 e 2; apresentados na Tabela 9.

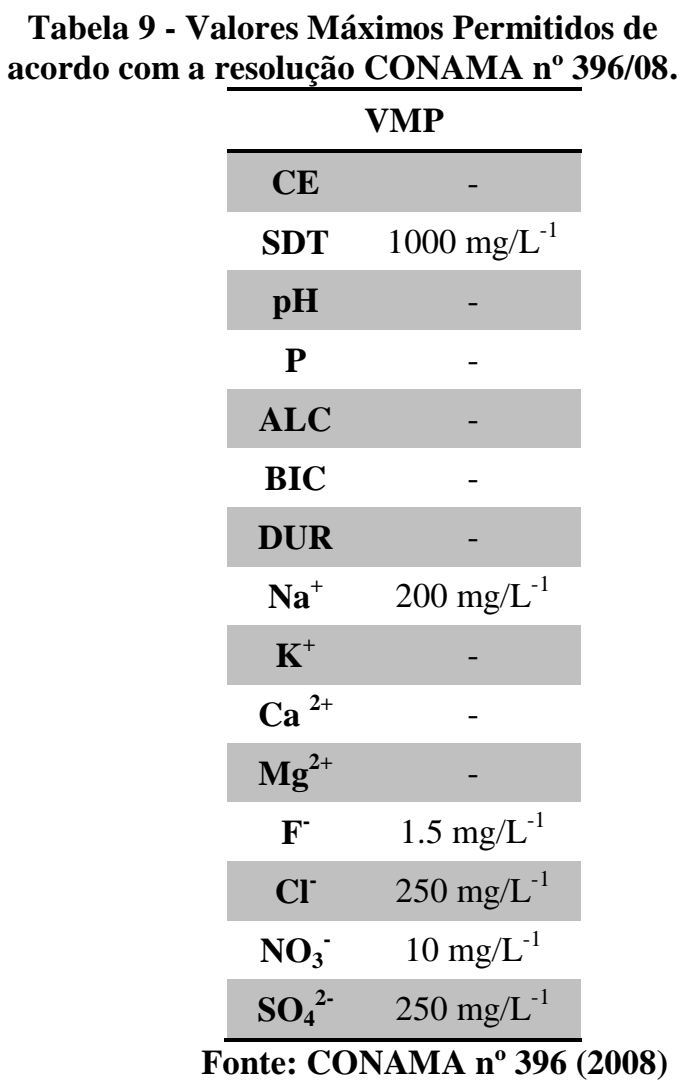

Não há valores de referência expressos no CONAMA 396 para todas as variáveis analisadas. Assim, como forma de complementação optou-se por acrescentar valores da Portaria $n^{\circ}$ 518/2004 do Ministério da Saúde para a dureza da água, no qual seu valor máximo permitido é $500 \mathrm{mg} / \mathrm{L}^{-1}$ (BRASIL, 2004).

Assim como da resolução CONAMA 357 (2005) que dispõe sobre a classificação dos corpos de água e diretrizes ambientais para o enquadramento das águas superficiais, para $\mathrm{pH}$, com valor de referência entre 6 a 9; visto que a água subterrânea é responsável por $90 \%$ pelo fluxo de base dos rios, e pela sua perenização durante períodos de estiagem. Essa contribuição representa aproximadamente $13.000 \mathrm{~km}^{3} /$ ano no mundo todo, ou seja, quase 1/3 da descarga dos rios (Peixoto e Oort, 1990 apud Rebouças, 1999). 
Desta forma, foi realizada a análise com base nos valores medidos de cada variável de qualidade da água e do valor de referência, para identificar se os valores encontrados nos poços da BEARJ estão em conformidade com a legislação.

A maioria das observações se mostrou satisfatória, ou seja, os valores encontrados nos poços para as SDT, sódio, fluoreto, cloreto, sulfato, dureza e $\mathrm{pH}$ estão dentro do previsto na legislação de recursos hídricos. As variáveis que apresentaram valores em desconformidade com a legislação foram o valor mínimo permitido do $\mathrm{pH}$ e o valor máximo permitido do nitrato.

$\mathrm{Na}$ maioria dos poços o valor mínimo do $\mathrm{pH}$ foi abaixo do permitido. Entretanto, estes valores representam a acidez natural dos solos do bioma Cerrado, que varia de 5,6 a 6,85 (Carmo et al., 2005). Não sendo preocupante para a qualidade da água do lençol freático.

O nitrato também teve seus valores alterados nos meses de dezembro de 2014, e em fevereiro, abril, maio e junho de 2015. A contaminação por nitrato tem gerado preocupação ao longo dos anos tanto no Brasil, quanto em outros países, devido a esse composto ser indicador de contaminação antrópica (PROCEL, 2011).

A importância do monitoramento do nitrato evidencia se no artigo 12, parágrafo único na resolução CONAMA 396 (2008), que relata o fato dele ser um dos parâmetros selecionados que deverão fazer parte para subsidiar a proposta de enquadramentos das águas subterrâneas em classes.

Desta forma, infere-se que os valores alterados se referem somente ao poço 25 e que o restante está em consonância com o limite permitido pela legislação.

Como o surgimento do nitrato em concentrações altas pode ser devido a diversas situações e não é relativo à presença de uma única fonte (RESENDE, 2002). A hipótese dessa alteração consiste no poço está inserido em uma área com a presença de horticultura e fruticultura irrigada, sendo corroboradas por outras pesquisas.

No estudo realizado por Parron et al. (2009) na BEARJ, verificou-se, por análise de variância, que a concentrações nitrato nos poços em áreas de horticultura são significativamente maiores. 
A pesquisa realizada por Araújo (2006) também encontrou poços com valores anômalos, dentre eles o poço 25 , no qual expõe suas considerações "foram encontrados sacos de fertilizante NPK próximo ao local comprovando sua frequente utilização. Os valores anômalos obtidos são interpretados como originados pelo uso desse fertilizante".

\subsection{Regressão Quadrática Múltipla}

Os cálculos estatísticos de regressão quadrática múltipla geraram 101 modelos de predição da qualidade da água a partir das interações entre as variáveis dependentes e independentes. Assim, devido à quantidade de modelos, optou-se por fazer uma análise mais detalhada da variável fósforo (devido ter gerado 11 modelos e possuir $\mathrm{CV}$ alto, o que possibilita observar o comportamento anual) e focar nos detalhes mais importantes das demais variáveis dependentes (qualidade da água).

Ressalta-se que para a análise realizada a seguir, todos os modelos apresentados foram estatisticamente significativos.

\section{$\underline{\text { FÓSFORO }}$}

Os resultados da análise da regressão quadrática múltipla entre a variável fósforo e as variáveis independentes indicaram que o modelo adotado foi estatisticamente significativo. A variabilidade explicada pelo modelo (soma dos quadrados do modelo $\mathrm{SS}_{\mathrm{M}}$ ) foi de 0,779 , e a variabilidade não explicada (soma dos quadrados dos resíduos $\left.\mathrm{SS}_{\mathrm{R}}\right)$ foi de 0,087 , correspondendo a uma variação total $\left(\mathrm{SS}_{\mathrm{T}}\right)$ de 0,865 . A comparação entre a média dos quadrados da regressão $\left(\mathrm{MQ}_{\mathrm{M}}=0,43\right)$ e a média dos quadrados dos resíduos $(\mathrm{MQR}=0,005)$, explicou que a variação do fósforo pode ser explicada pelas diferenças existentes entre os valores das variáveis independentes incluídas no modelo.

A análise de variância apresentou valor de $F=7,971$ (significativo a $p<0,000$ ), aceitando-se a hipótese de que existe relação linear entre a variável dependente em pelo menos uma das variáveis independentes, ou seja, existe relação de causa-efeito entre a variável dependente e as independentes. O modelo apresentou um $R^{2}$ de 0.90 e um $R^{2}$ ajustado de 0.79 .

Mediante processo de redução do número de variáveis independentes a serem consideradas no modelo, utilizando o método backward, o teste t a $5 \%$ de significância selecionou as variáveis constante $\mathrm{k}$; cambissolo $\mathrm{x}_{1}$; gleissolo $\mathrm{x}_{2}$; neossolo quartzarênico 
$\mathrm{x}_{6}$; uso pastagem $\mathrm{x}_{9}$; uso área natural $\mathrm{x}_{12}$; nível $\mathrm{x}_{14}$; declividade $\mathrm{x}_{15}$; área contribuição $\mathrm{x}_{16}$; latossolo vermelho $2\left(\mathrm{x}_{4}\right)^{2}$; latossolo vermelho amarelo $2\left(\mathrm{x}_{5}\right)^{2}$; uso agricultura 2 $\left(\mathrm{x}_{8}\right)^{2}$; uso pastagem $2\left(\mathrm{x}_{9}\right)^{2}$; ; uso área construída2 $\left(\mathrm{x}_{10}\right)^{2}$; uso solo exposto2 $\left(\mathrm{x}_{11}\right)^{2}$; uso área natural $2\left(\mathrm{x}_{12}\right)^{2}$; nível $2\left(\mathrm{x}_{14}\right)^{2}$; declividade $2\left(\mathrm{x}_{15}\right)^{2}$ e área contribuição2 $\left(\mathrm{x}_{16}\right)^{2}$. As estimativas dos coeficientes das variáveis independentes e da constante para o modelo de regressão quadrática múltipla encontram-se na Tabela 10.

Tabela 10 - Coeficientes estimados e padronizados relativos ao teste t, no intervalo de confiança de $95 \%$ para os coeficientes da regressão quadrática múltipla para a variável fósforo e sua relação com uso da terra, solo, área de contribuição, nível e declividade dos poços da BEARJ para o mês de julho de 2014.

\begin{tabular}{|c|c|c|c|c|c|c|c|}
\hline \multirow{3}{*}{ Variável } & \multicolumn{3}{|c|}{ Coeficiente } & \multirow{3}{*}{$\begin{array}{c}\text { Teste } \\
\mathbf{T}\end{array}$} & \multirow{3}{*}{ Sig. } & \multicolumn{2}{|c|}{$\begin{array}{c}\text { Intervalo de confiança } \\
\text { de } 95 \% \text { para B }\end{array}$} \\
\hline & \multirow{2}{*}{$\begin{array}{c}\text { Não } \\
\text { padronizado }\end{array}$} & \multicolumn{2}{|c|}{ Padronizado } & & & & \\
\hline & & Erro-padrão & $\boldsymbol{\beta}$ & & & Inferior & Superior \\
\hline $\mathrm{k}$ & 4.844 & 0.800 & & 6.052 & 0.000 & 3.147 & 6.541 \\
\hline $\mathrm{x}_{1}$ & 0.520 & 0.195 & 0.998 & 2.666 & 0.017 & 0.107 & 0.934 \\
\hline $\mathrm{x}_{2}$ & 1.421 & 0.663 & 0.204 & 2.142 & 0.048 & 0.015 & 2.828 \\
\hline $\mathrm{x}_{6}$ & 20.251 & 3.964 & 6.705 & 5.109 & 0.000 & 11.849 & 28.654 \\
\hline $\mathrm{x}_{9}$ & -8.961 & 1.142 & -12.615 & -7.849 & 0.000 & -11.381 & -6.541 \\
\hline $\mathrm{x}_{12}$ & -8.783 & 1.678 & -16.042 & -5.235 & 0.000 & -12.339 & -5.226 \\
\hline $\mathrm{x}_{14}$ & 0.058 & 0.019 & 1.523 & 2.962 & 0.009 & 0.016 & 0.099 \\
\hline $\mathrm{x}_{15}$ & 0.097 & 0.046 & 0.812 & 2.117 & 0.050 & 0.000 & 0.195 \\
\hline $\mathrm{x}_{16}$ & -0.008 & 0.002 & -2.056 & -3.675 & 0.002 & -0.012 & -0.003 \\
\hline$\left(x_{4}\right)^{2}$ & 0.372 & 0.122 & 0.937 & 3.037 & 0.008 & 0.112 & 0.632 \\
\hline$\left(\mathrm{x}_{5}\right)^{2}$ & 1.133 & 0.235 & 2.220 & 4.829 & 0.000 & 0.636 & 1.631 \\
\hline$\left(\mathrm{x}_{8}\right)^{2}$ & -5.070 & 0.825 & -12.097 & -6.145 & 0.000 & -6.819 & -3.321 \\
\hline$\left(x_{9}\right)^{2}$ & 3.037 & 0.724 & 2.758 & 4.193 & 0.001 & 1.501 & 4.572 \\
\hline$\left(x_{10}\right)^{2}$ & -5466.350 & 985.079 & -7.520 & -5.549 & 0.000 & -7554.625 & -3378.076 \\
\hline$\left(x_{11}\right)^{2}$ & -8.436 & 1.243 & -3.977 & -6.788 & 0.000 & -11.071 & -5.801 \\
\hline$\left(x_{12}\right)^{2}$ & 4.669 & 1.034 & 8.366 & 4.515 & 0.000 & 2.477 & 6.861 \\
\hline$\left(x_{14}\right)^{2}$ & -0.005 & 0.001 & -2.812 & -4.700 & 0.000 & -0.008 & -0.003 \\
\hline$\left(x_{15}\right)^{2}$ & -0.034 & 0.007 & -2.123 & -5.103 & 0.000 & -0.048 & -0.020 \\
\hline$\left(x_{16}\right)^{2}$ & 0.000 & 0.000 & 1.442 & 2.838 & 0.012 & 0.000 & 0.000 \\
\hline
\end{tabular}

Legenda: constante $\mathrm{k}$; cambissolo $\mathrm{x}_{1}$; gleissolo $\mathrm{x}_{2}$; neossolo quartzarênico $\mathrm{x}_{6}$; uso pastagem $\mathrm{x}_{9}$; uso área natural $\mathrm{x}_{12}$; nível $\mathrm{x}_{14}$; declividade $\mathrm{x}_{15}$; área contribuição $\mathrm{x}_{16}$; latossolo vermelho $2\left(\mathrm{x}_{4}\right)^{2}$; latossolo vermelho amarelo $2\left(\mathrm{x}_{5}\right)^{2}$; uso agricultura $2\left(\mathrm{x}_{8}\right)^{2}$; uso pastagem $2\left(\mathrm{x}_{9}\right)^{2} ;$; uso área construída2 $\left(\mathrm{x}_{10}\right)^{2}$; uso solo exposto2 $\left(\mathrm{x}_{11}\right)^{2}$; uso área natural 2 $\left(\mathrm{x}_{12}\right)^{2}$; nível $2\left(\mathrm{x}_{14}\right)^{2}$; declividade $2\left(\mathrm{x}_{15}\right)^{2} \mathrm{e}$ área contribuição2 $\left(\mathrm{x}_{16}\right)^{2}$.

Dos coeficientes estimados, apenas o uso pastagem, uso área natural e área contribuição apresentaram interação negativa com o fósforo. O coeficiente cambissolo, gleissolo, neossolo quartzarênico, nível e declividade evidenciaram interação positiva, e as demais variáveis apresentaram interações quadráticas; os valores dos coeficientes são positivos e negativos. 
Todos os coeficientes de regressão foram significativos $(\mathrm{p}<0,05)$, aceitando-se a hipótese de existência de uma relação linear significativa entre as variáveis independentes consideradas no modelo na contribuição da variável dependente (fósforo).

Os coeficientes de $\beta$ padronizados são todos mensurados em termos de unidades de desvios padrão e são diretamente comparáveis; correspondendo às contribuições das variáveis independentes sobre a variável dependente no modelo de regressão.

Deste modo, as maiores contribuições, para o fósforo, foram dadas por uso área natural 2, seguido por neossolo quartezarênico, uso pastagem 2, latossolo vermelho amarelo 2, nível, entre outras variáveis; para o mês de julho.

Levando em consideração todos os modelos gerados pode se inferir que com exceção do uso corpo d'água, as outras variáveis interagiram com o fósforo, entretanto as que mais o fizeram foram uso pastagem, uso agricultura 2 e nível 2.

A Tabela 11 é referente aos coeficientes $\beta$ padronizados que mais tiveram efeito sobre o fósforo em cada mês que foi gerado o modelo de regressão múltipla. Ou seja, no mês de julho a variável uso área natural 2 foi a que mais contribuiu para o fósforo com $\beta$ padronizado de 8,37 ; em agosto pode se observar que também foi a mesma variável porém com $\beta$ menor, 3,73; já em setembro o coeficiente de maior efeito foi o plintossolo 2 com $\beta 0,67$.

Tabela 11 - Coeficientes $\beta$ padronizados relativos às variáveis independentes dos modelos da regressão quadrática múltipla que conferiram maior contribuição para a variável fósforo em determinado mês.

\begin{tabular}{ccc}
\hline Mês & Variável & $\begin{array}{c}\text { Coeficiente } \boldsymbol{\beta} \\
\text { padronizado }\end{array}$ \\
\hline JUL/14 & $\left(\mathrm{x}_{12}\right)^{2}$ & 8,37 \\
AGO/14 & $\left(\mathrm{x}_{12}\right)^{2}$ & 3,73 \\
SET/14 & $\left(\mathrm{x}_{7}\right)^{2}$ & 0,67 \\
OUT/14 & $\left(\mathrm{x}_{4}\right)^{2}$ & 1,79 \\
NOV/14 & $\left(\mathrm{x}_{12}\right)^{2}$ & 9,99 \\
JAN/15 & $\mathrm{x}_{12}$ & 6,67 \\
FEV/15 & $\left(\mathrm{x}_{12}\right)^{2}$ & 5,95 \\
MAR/15 & $\left(\mathrm{x}_{12}\right)^{2}$ & 3,92 \\
ABR/15 & $\mathrm{x}_{5}$ & 7,25 \\
MAI/15 & $\mathrm{x}_{6}$ & 2,45 \\
JUN/15 & $\mathrm{x}_{5}$ & 4,21 \\
\hline
\end{tabular}


Estes resultados explicam a interação entre a variável fósforo e as características naturais e antrópicas nos poços da BEARJ, ou seja, estes fatores explicam a variável resposta. Portanto, caso haja alguma modificação nos mesmos, isso irá influencia-la (fósforo). Corroborando o estudo de Parron et al. (2009) no qual concluíram que a química da água subterrânea pode ser utilizada como indicador ambiental de mudanças no uso do solo.

\section{CONDUTIVIDADE ELÉTRICA E SÓLIDOS DISSOLVIDOS TOTAIS}

Estas duas variáveis medem os íons dissolvidos na água, o que lhes confere forte correlação, desta forma, ambos obtiveram resultados semelhantes, gerando 5 modelos de regressão múltipla nos meses de julho, agosto, janeiro, fevereiro e março.

As variáveis independentes explicaram tanto CE, quando os SDT, exceto neossolo, neossolo2, plintossolo 2, uso agricultura, uso corpo d'água, uso corpo d'água 2; nos 5 meses analisados, salvo no mês de janeiro.

Na Tabela 12 são apresentados os coeficientes $\beta$ padronizados que tiveram mais efeito nas variáveis dependentes, no qual foram o latossolo vermelho (aproximadamente 8.4), seguido do cambissolo $2(6,09)$ para ambas.

Tabela 12 - Coeficientes $\beta$ padronizados relativos às variáveis independentes dos modelos da regressão quadrática múltipla que conferiram maior contribuição para as variáveis condutividade elétrica e sólidos dissolvidos totais em determinado mês.

\begin{tabular}{cccc}
\hline Mês & Variável & $\begin{array}{c}\text { Coeficiente } \boldsymbol{\beta} \\
\text { padronizado - CE }\end{array}$ & $\begin{array}{c}\text { Coeficiente } \boldsymbol{\beta} \\
\text { padronizado - SDT }\end{array}$ \\
\hline JUL/14 & $\left(\mathrm{x}_{12}\right)^{2}$ & 2,87 & 2,86 \\
AGO/14 & $\left(\mathrm{x}_{5}\right)^{2}$ & 2,40 & 2,40 \\
JAN/15 & $\mathrm{x}_{4}$ & 8,54 & 8,36 \\
FEV/15 & $\left(\mathrm{x}_{1}\right)^{2}$ & 6,09 & 6,09 \\
MAR/15 & $\left(\mathrm{x}_{5}\right)^{2}$ & 2,63 & 2,63
\end{tabular}

Legenda: latossolo vermelho $\mathrm{x}_{4}$; cambissolo $2\left(\mathrm{x}_{1}\right)^{2}$; latossolo-vermelho-amarelo $2\left(\mathrm{x}_{5}\right)^{2}$; área natural $2\left(\mathrm{x}_{12}\right)^{2}$.

$\underline{\mathrm{pH}}$

O pH foi a única variável que gerou os 12 modelos de regressão múltipla e todas as variáveis explicativas tiveram influência ao decorrer do ano, exceto uso agricultura e 
uso corpo d'água 2. As variáveis explicativas (independentes) que mais vezes interagiram com o $\mathrm{pH}$ foram gleissolo e declividade 2. $\mathrm{O}$ coeficiente de $\beta$ padronizado que ofereceu a maior contribuição no modelo foi uso área natural $(29,46)$, no mês de abril. A Tabela 13 apresentam os coeficientes $\beta$ que mais contribuíram para o $\mathrm{pH}$ em cada mês.

Tabela 13 - Coeficientes $\beta$ padronizados relativos às variáveis independentes dos modelos da regressão quadrática múltipla que conferiram maior contribuição para a variável pH em determinado mês.

\begin{tabular}{|c|c|c|}
\hline Mês & Variável & $\begin{array}{l}\text { Coeficiente } \beta \\
\text { padronizado }\end{array}$ \\
\hline JUL/14 & $\mathrm{x}_{2}$ & 4,24 \\
\hline AGO/14 & $\mathrm{x}_{13}$ & 18,70 \\
\hline SET/14 & $\mathrm{x}_{12}$ & 4,95 \\
\hline OUT/14 & $\left(x_{9}\right)^{2}$ & 2,69 \\
\hline NOV/14 & $\mathrm{x}_{12}$ & 6,54 \\
\hline DEZ/14 & $\mathrm{x}_{12}$ & 7,53 \\
\hline JAN/15 & $\mathrm{x}_{13}$ & 12,21 \\
\hline FEV/15 & $\mathrm{x}_{13}$ & 6,66 \\
\hline MAR/15 & $\mathrm{x}_{13}$ & 18,24 \\
\hline ABR/15 & $\mathrm{x}_{12}$ & 29,46 \\
\hline MAI/15 & $\mathrm{x}_{12}$ & 5,05 \\
\hline JUN/15 & $\left(\mathrm{x}_{7}\right)^{2}$ & 0,44 \\
\hline
\end{tabular}

\section{ALCALINIDADE E BICARBONATO}

Os dados de bicarbonatos são obtidos através da Eq. 1, onde são necessários valores de alcalinidade e pH. Uma das características da alcalinidade é que sua capacidade de neutralização de ácidos está relacionada à presença de bicarbonatos, carbonatos e hidróxidos, e estes são determinados pelo $\mathrm{pH}$.

Desta forma, valores de $\mathrm{pH}$ entre 4,4 e 8,3 apresentam apenas o composto de bicarbonato. Nas águas subterrâneas da bacia, todos os poços ao longo dos 12 meses, possuem valores de $\mathrm{pH}$ entre 4,26 a 7,23, sendo dentro da faixa que se encontra o composto, isso explica a forte correlação entre as variáveis. 
Por isso, os resultados da regressão da alcalinidade e do bicarbonato se assemelharam bastante. Ambos geraram modelos para 6 meses do ano, sendo eles: julho, agosto, setembro, dezembro, janeiro e fevereiro.

Ambos somente não fizeram interação com as variáveis explicativas área de contribuição 2, latossolo amarelo 2, plintossolo, agricultura e corpo d'água 2. E as que interagiram mais vezes foram declividade 2, neossolo quartzarênico, nível 2 e área de construção 2.

A Tabela 14 apresenta os coeficientes $\beta$ padronizados que mais contribuíram para alcalinidade e bicarbonato em cada mês que o modelo foi gerado. Pode se perceber que o $\beta(13,26$ - 12,73) do uso área natural foi o que mais influenciou as variáveis dependentes no mês de dezembro.

Tabela 14 - Coeficientes $\beta$ padronizados relativos às variáveis independentes dos modelos da regressão quadrática múltipla que conferiram maior contribuição para as variáveis alcalinidade e bicarbonato em determinado mês.

\begin{tabular}{cccc}
\hline Mês & Variável & $\begin{array}{c}\text { Coeficiente } \boldsymbol{\beta} \\
\text { padronizado - ALC }\end{array}$ & $\begin{array}{c}\text { Coeficiente } \boldsymbol{\beta} \\
\text { padronizado - BIC }\end{array}$ \\
\hline JUL/14 & $\left(\mathrm{x}_{10}\right)^{2}$ & 6,33 & 6,22 \\
AGO/14 & $\mathrm{x}_{13}$ & 4,02 & 3,88 \\
SET/14 & $\mathrm{x}_{10}$ & 2,65 & - \\
DEZ/14 & $\left(\mathrm{x}_{9}\right)^{2}$ & - & 5,53 \\
JAN/15 & $\left(\mathrm{x}_{12}\right.$ & 13,26 & 12,73 \\
FEV/15 & $\left(\mathrm{x}_{10}\right)^{2}$ & 3,85 & 3,46 \\
MAR/15 & $\left(\mathrm{x}_{10}\right)^{2}$ & 9,43 & 9,37 \\
\hline
\end{tabular}

Legenda: uso área construída $\mathrm{x}_{10}$; área natural $\mathrm{x}_{12}$; uso corpo d'água $\mathrm{x}_{13}$; uso pastagem 2 $\left(\mathrm{x}_{9}\right)^{2}$; uso área construída $2\left(\mathrm{x}_{10}\right)^{2}$.

\section{DUREZA}

A dureza da água gerou 10 modelos de regressão múltipla e interagiu com todas as variáveis independentes nos diversos meses, salvo plintossolo, uso agricultura e uso corpo d'água 2. As variáveis quadráticas nível 2, declividade 2 e latossolo vermelhoamarelo 2 foram as que mais se repetiram nos modelos.

$\mathrm{Na}$ Tabela 15 estão apresentados os coeficientes $\beta$ padronizados que tiveram maior efeito sobre a dureza nos diferentes meses. Pode inferir que a área natural, no mês de maio, obteve a maior influência com $\beta$ igual a 21,81 . 
Tabela 15 - Coeficientes $\beta$ padronizados relativos às variáveis independentes dos modelos da regressão quadrática múltipla que conferiram maior contribuição para a variável dureza em determinado mês.

\begin{tabular}{ccc}
\hline Mês & Variável & $\begin{array}{c}\text { Coeficiente } \beta \\
\text { padronizado }\end{array}$ \\
\hline JUL/14 & $\left(\mathrm{x}_{5}\right)^{2}$ & 8,84 \\
AGO/14 & $\left(\mathrm{x}_{10}\right)^{2}$ & 3,93 \\
SET/14 & $\left(\mathrm{x}_{5}\right)^{2}$ & 2,09 \\
OUT/14 & $\mathrm{x}_{13}$ & 5,29 \\
NOV/14 & $\left(\mathrm{x}_{12}\right)^{2}$ & 4,43 \\
DEZ/14 & $\left(\mathrm{x}_{10}\right)^{2}$ & 3,84 \\
JAN/15 & $\left(\mathrm{x}_{5}\right)^{2}$ & 1,30 \\
FEV/15 & $\left(\mathrm{x}_{10}\right)^{2}$ & 9,08 \\
MAR/15 & $\left(\mathrm{x}_{5}\right)^{2}$ & 1,86 \\
MAI/15 & $\mathrm{x}_{12}$ & 21,81
\end{tabular}

Legenda: uso área natural $\mathrm{x}_{12}$; uso corpo d'água $\mathrm{x}_{13}$; latossolo vermelho amarelo $2\left(\mathrm{x}_{5}\right)^{2}$; uso área construída2 $\left(\mathrm{x}_{10}\right)^{2}$; uso área natural $2\left(\mathrm{x}_{12}\right)^{2}$.

\section{SÓDIO}

Seis modelos foram gerados para o sódio, no qual todas as variáveis independentes o explicaram, exceto quatro: plintossolo, plintossolo 2, uso agricultura e uso corpo d'água. Além da declividade 2, nível 2, uso agricultura 2 e pastagem que foram as que mais se repetiram nos 6 modelos.

Os coeficientes $\beta$ padronizados que mais influenciaram o sódio foram distintos em cada mês, variando em cambissolo, latossolo vermelho amarelo 2, neossolo quartzarênico, declividade, latossolo vermelho 2 e uso área natural 2. Como apresentado na Tabela 16.

Tabela 16 - Coeficientes $\beta$ padronizados relativos às variáveis independentes dos modelos da regressão quadrática múltipla que conferiram maior contribuição para a variável sódio em determinado mês.

\begin{tabular}{ccc}
\hline Mês & Variável & $\begin{array}{c}\text { Coeficiente } \beta \\
\text { padronizado }\end{array}$ \\
\hline JUL/14 & $\mathrm{x}_{6}$ & 12,13 \\
AGO/14 & $\mathrm{x}_{1}$ & 2,24 \\
SET/14 & $\mathrm{x}_{15}$ & 0,93 \\
OUT/14 & $\left(\mathrm{x}_{4}\right)^{2}$ & 1,98 \\
NOV/14 & $\left(\mathrm{x}_{12}\right)^{2}$ & 4,85 \\
JUN/15 & $\mathrm{x}_{5}$ & 9,37 \\
\hline
\end{tabular}


Legenda: cambissolo $\mathrm{x}_{1}$; latossolo vermelho amarelo $2 \mathrm{x}_{5}$; neossolo quartzarênico $\mathrm{x}_{6}$; declividade $\mathrm{x}_{15}$; latossolo vermelho $2\left(\mathrm{x}_{4}\right)^{2}$; uso área natural $2\left(\mathrm{x}_{12}\right)^{2}$.

\section{CÁLCIO}

Foram gerados 8 modelos para esta variável, no qual obteve diversas interações com as variáveis independentes, sendo com o uso área construída 2, a que mais destas, se repetiu. Entretanto, não apresentou interações com latossolo vermelho, plintossolo, uso agricultura, uso solo exposto e corpo d'água 2 . $\mathrm{O}$ uso área construída 2 também foi o coeficiente $\beta$ padronizado que mais efeito aplicou sobre o cálcio, repetindo se 5 vezes; como exposto na Tabela 17.

Tabela 17 - Coeficientes $\beta$ padronizados relativos às variáveis independentes dos modelos da regressão quadrática múltipla que conferiram maior contribuição para a variável cálcio em determinado mês.

\begin{tabular}{ccc}
\hline Mês & Variável & $\begin{array}{c}\text { Coeficiente } \beta \\
\text { padronizado }\end{array}$ \\
\hline JUL/14 & $\left(\mathrm{x}_{1}\right)^{2}$ & 4,90 \\
AGO/14 & $\left(\mathrm{x}_{10}\right)^{2}$ & 8,78 \\
SET/14 & $\left(\mathrm{x}_{1}\right)^{2}$ & 3,75 \\
OUT/14 & $\left(\mathrm{x}_{10}\right)^{2}$ & 5,44 \\
DEZ/14 & $\left(\mathrm{x}_{10}\right)^{2}$ & 4,62 \\
JAN/15 & $\left(\mathrm{x}_{10}\right)^{2}$ & 3,61 \\
FEV/15 & $\left(\mathrm{x}_{10}\right)^{2}$ & 8,19 \\
MAR/15 & $\mathrm{x}_{13}$ & 2,59 \\
\hline
\end{tabular}

Legenda: uso corpo d'água $\mathrm{x}_{13}$; cambissolo $2\left(\mathrm{x}_{1}\right)^{2}$; uso área construída2 $\left(\mathrm{x}_{10}\right)^{2}$.

\section{MAGNÉSIO}

As interações entre as variáveis independentes e o magnésio geraram 10 modelos mensais de regressão múltipla, onde o plintossolo, plintossolo 2, neossolo quartzarênico 2, uso agricultura e uso corpo d'água 2 não explicaram/interagiram com o modelo. As variáveis quadráticas uso agricultura 2 e uso pastagem 2 foram as que mais se repetiram nos meses. No mês de julho, o neossolo quartzarênico obteve o maior coeficiente $\beta$ padronizado; 12,17. Como pode ser observado na Tabela 18. 
Tabela 18 - Coeficientes $\beta$ padronizados relativos às variáveis independentes dos modelos da regressão quadrática múltipla que conferiram maior contribuição para a variável magnésio em determinado mês.

\begin{tabular}{ccc}
\hline Mês & Variável & $\begin{array}{c}\text { Coeficiente } \beta \\
\text { padronizado }\end{array}$ \\
\hline JUL/14 & $\mathrm{x}_{6}$ & 12,17 \\
AGO/14 & $\left(\mathrm{x}_{9}\right)^{2}$ & 2,15 \\
SET/14 & $\left(\mathrm{x}_{9}\right)^{2}$ & 2,11 \\
OUT/14 & $\mathrm{x}_{13}$ & 3,54 \\
NOV/14 & $\left(\mathrm{x}_{12}\right)^{2}$ & 4,10 \\
DEZ/14 & $\mathrm{x}_{12}$ & 5,00 \\
JAN/15 & $\mathrm{x}_{1}$ & 3,10 \\
FEV/15 & $\left(\mathrm{x}_{5}\right)^{2}$ & 4,84 \\
MAR/15 & $\left(\mathrm{x}_{5}\right)^{2}$ & 6,99 \\
MAI/15 & $\mathrm{x}_{15}$ & 2,02
\end{tabular}

Legenda: cambissolo $\mathrm{x}_{1}$; neossolo quartzarênico $\mathrm{x}_{6}$; uso área natural $\mathrm{x}_{12}$; uso corpo d'água $\mathrm{x}_{13}$; declividade $\mathrm{x}_{15}$; latossolo vermelho amarelo $2\left(\mathrm{x}_{5}\right)^{2}$; uso pastagem $2\left(\mathrm{x}_{9}\right)^{2}$; uso área natural $2\left(\mathrm{x}_{12}\right)^{2}$.

\section{$\underline{\text { CLORETO }}$}

Esta variável gerou 2 modelos de regressão múltipla, que se referem aos meses de agosto de 2014 e janeiro de 2015. Em decorrência deste fato, as interações com as variáveis independentes ocorreram em menor quantidade sendo elas: área de contribuição; área de contribuição 2; cambissolo; declividade 2; gleissolo; gleissolo 2; latossolo amarelo 2; latossolo vermelho; latossolo vermelho 2; latossolo vermelho amarelo 2; neossolo quartzarênico; neossolo quartzarênico 2; nível; nível 2; plintossolo 2; uso agricultura 2; uso área natural; uso corpo d'água; uso pastagem; uso solo exposto 2. A que mais vezes se repetiu foi área de contribuição e pastagem.

Os coeficientes $\beta$ padronizados que mais influenciaram o cloreto foram as variáveis: uso corpo d'água, no mês de agosto, 8,40 e em janeiro foi o latossolo vermelho 17,40, como exposto na Tabela 19.

Tabela 19 - Coeficientes $\beta$ padronizados relativos às variáveis independentes dos modelos da regressão quadrática múltipla que conferiram maior contribuição para a variável cloreto em determinado mês.

\begin{tabular}{ccc}
\hline Mês & Variável & $\begin{array}{c}\text { Coeficiente } \boldsymbol{\beta} \\
\text { padronizado }\end{array}$ \\
\hline AGO/14 & $\mathrm{x}_{13}$ & 8,40 \\
JAN/15 & $\mathrm{x}_{4}$ & 17,94 \\
\hline
\end{tabular}




\section{POTÁSSIO}

Esta variável também gerou somente 2 modelos de regressão múltipla, que se referem aos meses de julho e agosto de 2014. As interações que não ocorreram foram com as variáveis independentes declividade 2; plintossolo; plintossolo2; neossolo quartzarênico 2; uso corpo d'água; uso corpo d'água 2; uso agricultura, uso área natural 2; uso pastagem 2 e uso solo exposto.

A Tabela 20 exibe os coeficientes $\beta$ padronizados que tiveram maior efeito no potássio foram as variáveis latossolo vermelho $(19,01)$ e cambissolo $(5,28)$; em julho e agosto, respectivamente.

Tabela 20 - Coeficientes $\beta$ padronizados relativos às variáveis independentes dos modelos da regressão quadrática múltipla que conferiram maior contribuição para a variável potássio em determinado mês.

\begin{tabular}{ccc}
\hline Mês & Variável & $\begin{array}{c}\text { Coeficiente } \boldsymbol{\beta} \\
\text { padronizado }\end{array}$ \\
\hline JUL/14 & $\mathrm{x}_{4}$ & 19,01 \\
AGO/14 & $\mathrm{x}_{1}$ & 5,48 \\
\hline \multicolumn{2}{l}{ Legenda: cambissolo $\mathrm{x}_{1 ;}$ latossolo vermelho $\mathrm{x}_{4}}$.
\end{tabular}

\section{$\underline{\text { FLUORETO }}$}

As interações entre as variáveis independentes e o fluoreto geraram 9 modelos mensais e em todos eles o fluoreto interagiu com as variáveis independentes, exceto uso agricultura, neossolo quartzarênico 2 e corpo d'água 2. Sendo as variáveis uso pastagem e uso agricultura 2 as que mais se repetiram ao longo dos meses.

Em cada mês houve uma variável que teve maior efeito sobre o fluoreto e estas estão descritas na Tabela 21. No mês de dezembro o uso área natural obteve o maior coeficiente $\beta$ padronizado; 35,50 .

Tabela 21 - Coeficientes $\beta$ padronizados relativos às variáveis independentes dos modelos da regressão quadrática múltipla que conferiram maior contribuição para a variável fluoreto em determinado mês.

\begin{tabular}{ccc}
\hline Mês & Variável & $\begin{array}{c}\text { Coeficiente } \boldsymbol{\beta} \\
\text { padronizado }\end{array}$ \\
\hline JUL/14 & $\left(\mathrm{x}_{12}\right)^{2}$ & 10,99 \\
AGO/14 & $\left(\mathrm{x}_{9}\right)^{2}$ & 1,89 \\
SET/14 & $\left(\mathrm{x}_{9}\right)^{2}$ & 1,37 \\
OUT/14 & $\mathrm{x}_{13}$ & 3,58 \\
NOV/14 & $\mathrm{x}_{2}$ & 4,33
\end{tabular}




\begin{tabular}{|c|c|c|}
\hline DEZ/14 & $\mathrm{x}_{12}$ & 35,50 \\
\hline FEV/15 & $\left(x_{9}\right)^{2}$ & 1,43 \\
\hline MAI/15 & $\mathrm{x}_{6}$ & 6,26 \\
\hline JUN/15 & $\left(\mathrm{x}_{10}\right)^{2}$ & 3,53 \\
\hline
\end{tabular}

\section{$\underline{\text { NITRATO }}$}

Nos meses de julho, setembro e outubro o nitrato interagiu significativamente com a maioria das variáveis independentes analisados, exceto declividade; declividade 2; plintossolo; plintossolo 2; neossolo quartzarênico 2; uso corpo d'água, corpo d'água 2, uso agricultura; uso área construída 2, uso pastagem 2 e solo exposto. Sendo que os latossolos (vermelho 2 e vermelho-amarelo 2), cambissolo e área natural 2 foram as variáveis que interagiram repetidas vezes.

Nos meses de julho e setembro a variável latossolo vermelho apresentou maior coeficiente de interação com o nitrato; já em outubro foi o latossolo vermelho, como exposto na Tabela 22.

Tabela 22 - Coeficientes $\beta$ padronizados relativos às variáveis independentes dos modelos da regressão quadrática múltipla que conferiram maior contribuição para a variável nitrato em determinado mês.

\begin{tabular}{ccc}
\hline Mês & Variável & $\begin{array}{c}\text { Coeficiente } \beta \\
\text { padronizado }\end{array}$ \\
\cline { 2 - 3 } JUL/14 & $\left(\mathrm{x}_{5}\right)^{2}$ & 8,19 \\
SET/14 & $\left(\mathrm{x}_{5}\right)^{2}$ & 3,23 \\
OUT/14 & $\mathrm{x}_{4}$ & 8,93 \\
\hline Legenda: latossolo vermelho $\mathrm{x}_{4}$; latossolo vermelho amarelo $2\left(\mathrm{x}_{5}\right)^{2}$.
\end{tabular}

\section{$\underline{\text { SULFATO }}$}

O sulfato gerou 4 modelos referente aos meses julho, agosto e setembro de 2014 e janeiro de 2015. As variáveis independentes que mais interagiram com o sulfato foram as quadráticas que são: gleissolo 2; latossolo amarelo 2; latossolo vermelho amarelo $2 \mathrm{e}$ plintossolo 2. A Tabela 23 exibe os coeficientes $\beta$ padronizados que tiveram maior efeito no sulfato, que foram nos respectivos meses neossolo quartzarênico, uso área natural, plintossolo 2 e latossolo vermelho. 
Tabela 23 - Coeficientes $\beta$ padronizados relativos às variáveis independentes dos modelos da regressão quadrática múltipla que conferiram maior contribuição para a variável sulfato em determinado mês.

\begin{tabular}{ccc}
\hline Mês & Variável & $\begin{array}{c}\text { Coeficiente } \boldsymbol{\beta} \\
\text { padronizado }\end{array}$ \\
\hline JUL/14 & $\mathrm{x}_{6}$ & 6,39 \\
AGO/14 & $\mathrm{x}_{12}$ & 14,96 \\
SET/14 & $\left(\mathrm{x}_{7}\right)^{2}$ & 0,92 \\
JAN/15 & $\mathrm{x}_{4}$ & 15,44 \\
\hline Legenda: latossolo vermelho $\mathrm{x}_{4} ;$ neossolo quartzarênico $\mathrm{x}_{6} ;$
\end{tabular}

Os resultados gerados indicam que determinadas variáveis de qualidade da água são mais influenciadas/explicadas pelas características ambientais e antrópicas (variáveis independentes) sendo elas: $\mathrm{pH}$, seguido do fósforo, dureza e magnésio; devido a quantidade de modelos gerados mensalmente para cada variável dependente $(12,11,10$ e 10; respectivamente).

Entretanto, há variáveis como o cloreto e o potássio, que as características naturais e antrópicas não conseguiram explicar a maior parte dos meses, pois foi gerado apenas 2 modelos de regressão para cada; podendo sofrer influência de características que este estudo não abrangeu.

As variáveis independentes resultantes foram bastante variadas ao longo dos meses, não ficando evidente qual exerce mais influência sobre a variável de qualidade de água de forma geral; ou seja, essa resposta é pontual (mensal) como pode ser evidenciado nas Tabelas 11 a 23, a partir do coeficiente $\beta$ padronizado.

Desta forma, para que os modelos estatísticos representem bem um fenômeno, é necessário se conhecer a verdadeira relação entre as variáveis dependente e independente, para que se possam fazer inferências estatísticas precisas com utilidade prática (REGAZZI e LEITE, 1992).

Portanto, em geral, as variáveis independentes que mais vezes apareceram em todos os modelos foram as classes de solo, e os usos agricultura e pastagem. As classes de solo (mais precisamente os latossolos) e estes usos estão fortemente vinculados na área de estudo, pois, o Cerrado, em sua maioria, possui latossolos, porém, estes não são os solos mais férteis para a prática agrícola, além de terem acidez e teores de alumínio elevados. Deste modo, estes fatos contribuem para o aumento do uso de corretivos 
(calcário) e fertilizantes, para que assim, alcancem produtividades satisfatórias (SILVA et al., 2001).

Essa baixa fertilidade do solo ocorre pela deficiência de determinados nutrientes, que são essenciais para o crescimento de cada planta, assim, estes são incrementados por meio da adubação química e orgânica (OLIVEIRA-FILHO; LIMA, 2002).

Segundo Silva et al. (2001), os nutrientes mais importantes para os cultivos são os macronutrientes nitrogênio $(\mathrm{N})$, potássio $(\mathrm{K})$, fósforo $(\mathrm{P})$, cálcio $(\mathrm{Ca})$, magnésio $(\mathrm{Mg})$ e enxofre (S).

Entretanto, estes incrementos e nutrientes podem ter efeitos na qualidade da água. Contudo, as camadas do solo, podem até atenuar determinados contaminantes, porém, se o descarte da carga for feita de maneira inadequada, determinados componentes podem vir a poluir os aquíferos (RIBEIRO et al., 2007).

Assim, há elementos que auxiliam na indicação de possíveis contaminações das atividades agrícolas, pois, refletem na qualidade da água, já que estão presentes em agrotóxicos, corretivos e fertilizantes. Alguns exemplos são o fósforo, sódio, potássio, cálcio, magnésio, ferro, manganês, zinco, cobre, molibdênio e ânions como cloreto, nitrato, bicarbonato e fosfato (ARAÚJO, 2006).

$\mathrm{O}$ nitrogênio, encontrado principalmente na forma de nitrato $\left(\mathrm{NO}_{3}{ }^{-}\right)$, veem se acumulando nas águas subterrâneas, pois sua carga negativa não o permite ficar retido no solo (BERTON, 1992).

Entretanto, quando se comparou os valores medidos com os VMP pela CONAMA $\mathrm{n}^{\text {o }} 396$ deste nutriente, evidenciou que apenas em um dos 38 poços piezométricos verificou-se inconformidade com a legislação.

Assim sendo, por mais que o uso da bacia seja predominantemente agrícola e se utilize incrementos agrícolas, a qualidade da água mostra se adequada, atendendo aos padrões definidos para águas subterrâneas de Classe 1 e 2 da Resolução CONAMA no 396/2008. 


\section{CONCLUSÕES}

1. Os resultados indicam que a qualidade da água do lençol freático (15 parâmetros) na Bacia Experimental do Alto Rio Jardim (38 poços), em geral, é adequada, considerando-se como referência os padrões definidos pela Resolução CONAMA 396/2008 para águas subterrâneas de Classe 1 e 2.

2. Em apenas um dos 38 poços piezométricos verificou-se inconformidade em relação aos valores máximos permitidos para a qualidade da água subterrânea (Resolução CONAMA 396/2008), no caso, a concentração de Nitrato.

3. A hipótese mais provável para a diferenciação da concentração de Nitrato no único poço em desconformidade com a Classe 2 é a presença de horticultura e fruticultura irrigada em seu entorno. No entanto, outros poços com a presença desses usos não apresentaram problemas similares em relação à qualidade da água.

4. Destaca-se que cerca de $80 \%$ da área de contribuição de todos os poços analisados (somatório) é de uso agrícola (agricultura e pecuária).

5. De forma geral, não foi possível identificar uma correlação evidente entre a qualidade da água do lençol freático e o uso e ocupação da terra na Bacia Experimental do Alto Rio Jardim (DF).

6. As análises estatísticas (regressão múltipla) indicam que o tipo de solo, a presença de agricultura e pastagem são as características que mais aparecem nas análises de influência sobre a qualidade da água nos poços. No entanto, ressalta-se mais uma vez, que as alterações verificadas, em geral, não representam problema de qualidade da água. 


\section{REFERÊNCIAS}

ADASA - Agência Reguladora de Águas, Energia e Saneamento Básico do Distrito Federal. Resolução/ADASA $n^{\circ}$ 01, de 28 de fevereiro de 2011. Define as disponibilidades hídricas dos aquíferos subterrâneos no território do Distrito Federal. Brasília: ADASA, 2011.

ADASA - Agência Reguladora de Águas, Energia e Saneamento Básico do Distrito Federal. Plano de Gerenciamento Integrado de Recursos Hídricos do Distrito Federal - PGIRH/DF. Relatório Final - Volume I - Diagnóstico - Jul/ 2012.

APHA - American Public Health Association. Standard methods for the examination of water and wastewater. 20 ed. Washington, DC, 1998. Part 2000, Method 2340B.

APHA (AMERICAN PUBLIC HEALTH ASSOCIATION). Standard methods for the examination of water and wastewater. 20 ed. Washington, DC, 1998. Part 4000, Method 4500-P Phosphorus.

APHA - American Public Health Association. Standard methods for the examination of water and wastewater. 22 ed. Washington, DC. 2005.

ARAL, H.; VECCHIO-SADUS, A. Toxicity of lithium to humans and the environment - A literature review. 2008. In: SAVAZZI, Eduardo Angelino. Sugestão de valores de referência de qualidade para os elementos químicos cobalto, estanho, fósforo, lítio, molibdênio, níquel, prata, tálio, titânio e vanádio em amostras de água subterrânea coletadas nos Aquíferos Bauru e Guarani, confo. Tese de Doutorado. Universidade de São Paulo.

ARAUJO, S. F. Hidroquímica dos aquíferos freáticos da bacia do rio Jardim- DF. 2006. 108p. Dissertação (Mestrado em Geociências) - Instituto de Geociências, Universidade de Brasília, Brasília, DF, 2006.

BERNARDO, S.; SOARES, A. A.; MANTOVANI, E. C. Manual de irrigação. $8^{a}$ edição - Viçosa: Editora UFV, 2006, 625p.

BERTON, R.S. Fertilizantes e poluição. In: Reunião Brasileira de Fertilidade do solo e nutrição de plantas, 20, Piracicaba, 1992. Anais. Campinas, Fundação Cargill, 1992. 425p.

BRASIL. Lei Federal no 9.433, de 8 de janeiro de 1997. Institui a Política Nacional de Recursos Hídricos, cria o Sistema Nacional de Gerenciamento de Recursos Hídricos, regulamenta o inciso XIX do art. 21 da Constituição Federal, e altera o art. $1^{\circ}$ da Lei ${ }^{\circ}$ 8.001, de 13 de março de 1990, que modificou a Lei n n $^{\circ} .990$, de 28 de dezembro de 1989. Brasília, DF, 1997.

BRASIL. Ministério da Saúde. Portaria $n^{\circ}$ 518, de 25 de março de 2004. Estabelece as responsabilidades por parte de quem produz a água, a quem cabe o exercício do controle de qualidade da água e das autoridades sanitárias e dá outras providências. 2004.

BUSSAB, W. O. Análise de variância e de regressão. São Paulo: Atual, 1986. 147p.

CABRAL, N. M. T. Teores de nitrato $\left(\mathrm{NO}_{3}{ }^{-}\right)$e amônio $\left(\mathrm{NH}_{4}{ }^{+}\right)$nas águas do aquiífero Barreiras nos bairros do Reduto, Nazaré e Umarizal - Belém/PA. Química Nova, Vol. 30, No. 8, 2007. 18041808 p.

CAMPOS, J. E. G. Hidrogeologia do Distrito Federal: bases para a gestão dos recursos hídricos subterrâneos. Revista Brasileira de Geociências, Volume 34, 2004. 34(1), março de 2004, 41- 48p.

CARMO, M.S., BOAVENTURA, G.R., OLIVEIRA, E.C. Geoquímica das Águas da Bacia Hidrográfica do Rio Descoberto, Brasília/DF - Brasil. Quimica Nova, 28, 2005. 565 -574p.

CEDERSTROM, D. J. Água subterrânea: Uma introdução. Centro de Publicações técnicas da aliança. Missão Norte-americana de cooperação econômica e técnica no Brasil - USAID. Rio de Janeiro, 1964. 
CETESB - Companhia Ambiental do Estado de São Paulo. Guia nacional de coleta e preservação de amostras: água, sedimento, comunidades aquáticas e efluentes líquidos. / Companhia Ambiental do Estado de São Paulo; Organizadores: Carlos Jesus Brandão [et al.]. -- São Paulo: CETESB; Brasília: ANA, 2011, 326p.

Chaves, T. A., GOMES, R. A. T., MARTins, É. D. S., CARVAlhO JÚNiOR, O. A. D., GUIMARÃES, R. F., \& REATTO, A. Comparação da perda de solo atual em relação ao ambiente natural na bacia do Rio Jardim - DF. Espaço \& Geografia, Vol.14, No 1, 95:125. Brasília, 2011. 31p.

CODEPLAN - Companhia de Planejamento do Distrito Federal. Sistema Cartográfico do Distrito Federal - SICAD. Cartas planialtimétricas em formato vetorial, na escala 1:10.000. Brasília, 1991.

CONAMA - Conselho Nacional do Meio Ambiente. Resolução CONAMA no 357, de 17 de março de 2005. Dispõe sobre a classificação dos corpos de água e diretrizes ambientais para o seu enquadramento, bem como estabelece as condições e padrões de lançamento de efluentes, e dá outras providências. Brasília: CONAMA, 2005.

CONAMA - Conselho Nacional do Meio Ambiente. Resolução CONAMA ñ 396, de 3 de abril de 2008. Dispõe sobre a classificação e diretrizes ambientais para o enquadramento das águas subterrâneas e dá outras providências. Brasília: CONAMA, 2008. 2350p.

CUSTÓDIO, E., LLAMAS, M. R. Hidrologia Subterrânea. Barcelona: Omega, 2a ed., vol. 1, 1983.

DEUTSCH, W. J. Groundwater Geochemistry: Fundamentals and Applications to Contamination. Lewis Publishers, Boca Raton, New York, 1997.

DOLABElla, R. H. C. Caracterização agroambiental e avaliação da demanda e da disponibilidade dos recursos hídricos para a agricultura irrigada na bacia hidrográfica do rio Jardim - DF. Brasília: UnB, Dissertação Mestrado, 1996, 106p.

EMATER-DF - Empresa de Assistência Técnica e Extensão Rural do DF. Conjuntura Socioeconômica Rural - RA VI Planaltina: Unidades Locais: Rio Preto Taquara, Tabatinga, Planaltina e Pipiripau. Secretaria de estado de Agricultura, Pecuária e Abastecimento/SEAPA-DF, EMATER - DF, 2009.

EMBRAPA - EMPRESA BRASILEIRA DE PESQUISA AGROPECUÁRIA. Centro de Pesquisa Agropecuária dos Cerrados, Planaltina, DF. Relatório Técnico anual 1975 - 1976. Brasília, DF, 1976 V. 1. 154p.

EMBRAPA - EMPRESA BRASILEIRA DE PESQUISA AGROPECUÁRIA. Centro de Pesquisa Agropecuária dos Cerrados, Planaltina, DF. Relatório Técnico anual 1976 - 1977. Brasília, DF, 1978 V. 1. 184p.

FARIA, G.; ZAMBERLAN, C. O.; DIAS, E. P.; CASTAGNA, G. Expansão da Fronteira Agrícola: Impacto das Políticas de Desenvolvimento Regional do Centro-oeste Brasileiro. Sociedade Brasileira de Economia, Administração e Sociologia Rural. Campo Grande: 2009. 12p.

FEITOSA, F. A. C.; MANOEL FILHO, J. Hidrogeologia: Conceitos e aplicações. $2^{a}$ edição Fortaleza: CPRM/ REFO, LABHID-UFPE, 2000, 391p.

FOSTER, S. S. D.; HIRATA, R. C. Evaluación del riesgo de contaminación de las aguas subterráneas - metodo de reconocimiento basado en datos existentes. CEPIS-OPS, Lima, Perú; Versión preliminar, 1988, 84p.

FORMAGGIO, L. F. Estudo da variabilidade da piezometria dos aquíferos freáticos na bacia do Alto rio Jardim - Distrito Federal. Dissertação de mestrado, Publicação IG - 2007, Instituto de Geociências, Universidade de Brasília, DF, 112p.

FORSYTHE, W. Fisica de suelos. Manual de laboratório. In: FERRARESI, T. M., et al. Espectroscopia de infravermelho na determinação da textura do solo. Revista Brasileira de Ciência do Solo, 2012, 36:1769-1777p. 
FOSTER, S. S. D.; HIRATA, R; GOMES, D; D’ELIA, M; PARIS, M. Proteção da Qualidade da Água Subterrânea: um guia para empresas de abastecimento de água, órgãos municipais e agências ambientais. São Paulo, Servemar. 2006.

FRANCO, J. B. S. O papel da Embrapa nas transformações do Cerrado. Caminhos de Geografia 2(3), mar/ 2001, 31 - 40p.

FRANKENBERGER JR, W. F.; MEHRA, H. C.; GJERD, D. T. Environmental applications of ion chromatography. J. Chrom., 504. 1990, 211-245p.

FREITAS-SILVA, F. H. \& CAMPOS J. E. G. Geologia do Distrito Federal. In: IEMA/SEMATEC/UnB 1998. Inventário Hidrogeológico e dos Recursos Hídricos Superficiais do Distrito Federal. Brasília. IEMA/SEMATEC/UnB. Vol. 1, Parte I, 1998, 86p. (Relatório Inédito).

GUERRA, A. T. \& GUERRA, A. J. T. Novo Dicionário Geológico-geomorfológico. Rio de Janeiro: Beltrand Brasil, 1997.

HAGER, F. P. V.; D’ALMEIDA, M. L. Legislação aplicada às águas subterrâneas. XV Congresso Brasileiro de Águas Subterrâneas. 2008.

HELENA, B.; PARDO, R.; VEGA, M.; BARRADO, E.; FERNANDEZ, J. M; FERNANDEZ, L. Temporal evolution of groundwater composition in an alluvial aquifer (Pisuerga river, Spain) by principal component analysis. Wat. Res. Vol. 34, No. 3, 2000, 807-816p.

HILDEBRANDT, A.; GUILLAMÓN, M.; LACORTE, S.; TAULER, R.; BARCELÓ, D. Impact of pesticides used in agriculture and vineyards to surface and groundwater quality (North Spain). Water Research. Vol. 42, 2008, 3315 - 3326p.

IBGE. Censo Demográfico 2000 - Características Gerais da População. Resultados da Amostra. IBGE, 2003.

IPEA - INSTITUTO DE PESQUISA ECONÔMICA APLICADA. Quatro Décadas de Crescimento Econômico no Centro-Oeste Brasileiro: Recursos Públicos em Ação. Texto para discussão no 712. ISSN 1415-4765. Brasília: 2000. 27p.

JÚNIOR, A. S. de A.; SILVA, Ê. F. de F. e; BASTOS, E. A.; MELO, F. de B.; LEAL, C. M. Uso e qualidade da água subterrânea para irrigação no Semi- Árido Piauiense. Revista Brasileira de Engenharia Agrícola e Ambiental. Vol.10, n.4, 2006, 873-880p.

KOLPIN, D. W.; BARBASH, J. E.; GILLIOM, R. J. Occurrence of pesticides in shallow groundwater of the United States: Initial results from the National Water-Quality Assessment Program. Environmental Science \& Technology / Vol. 32, No. 5, 1998, 558-566p.

KOLPIN, D. W.; THURMAN, E. M.; GOOLSBY, D. A. Occurrence of selected pesticides and their metabolites in near-surface aquifers of the Midwestern United States. Environmental science \& technology. Vol. 30, No. 1, 1996, 335-340p.

LIMA, C. V. Quantificação de taxa erosiva e estudo de perfis lateríticos da bacia do rio Jardim - DF. Tese de Doutorado em Geologia - Universidade de Brasília, Brasília, DF, 2002.115p.

LIMA, J. E. F. W. Modelagem numérica do fluxo da água no solo e do escoamento de base em uma bacia experimental em área agrícola no Cerrado. 2010. 312p. Tese (Doutorado em Engenharia Civil e Ambiental - PTARH Tese de Doutorado, Publicação PTARH. TD - 08/10, Departamento de Engenharia Civil e Ambiental, Universidade de Brasília, Brasília, DF, 2010. 312p.

LIMA, J. E. F. W.; SILVA, E. M. da; EID, N. J.; MARTINS, E. de S.; KOIDE, S.; REATTO, A. Desenvolvimento e verificação de métodos indiretos para a estimativa da erodibilidade dos solos da bacia experimental do Alto Rio Jardim - DF. Revista Brasileira de Geomorfologia, v. 8, n. 2, 2007, 21-34p.

LIMA, S. C. As veredas do Ribeirão Panga no Triângulo Mineiro e a evolução da paisagem. São Paulo: USP, 1996. 260p. (Tese, Doutorado em Geografia Física). 
MELIAN, R.; MIRLEAN, N.; GOURIEV, A.; MOURARU, K.; RADSTAKE, F. Ground water qualirty and rural drinjking-water supply in the Republic Moldova. Hydrogeology Journal. Springer, v. 7, n. 2, 1999, 188-196p.

MOURA, L. H. A. Estudo geoquímico da Bacia do Gama e avaliação da qualidade da água. Dissertação (mestrado), IG/UNB, Brasília, 2008. 129p.

MUNIZ, D. H. F.; MORAES, A. S.; FREIRE, I. S.; CRUZ, C. J. D.; LIMA, J. E. F. W.;OLIVEIRAFILHO, E. C. Avaliação dos impactos urbano e agrícola sobre a qualidade da água de rios do Distrito Federal. XIX Simpósio Brasileiro de Recursos Hídricos. 2011.

MYERS, R. H. Classical and modern regression with applications. 2. ed. Duxbury Classic: Boston, MA, 2000.

OLIVEIRA-FILHO E. C.; LIMA, J. E. F. W. Impacto da agricultura sobre os recursos hídricos na região do cerrado. Planaltina, DF: Embrapa Cerrados, Documentos Embrapa Cerrados. 2002, 50p.

OLIVEIRA, P. T. S. de; SOBRINHO, T. A.; STEFFEN, J. L.; RODRIGUES, D. B. B. Caracterização morfométrica de bacias hidrográficas através de dados SRTM. Revista Brasileira de Engenharia Agrícola e Ambiental, v.14, n.8, 2010, 819-825p.

PARRON, L. M.; LIMA, J. E. F. W.; CRUZ, C. J. D.; FRANCISCON, L. Qualidade da água subterrânea como indicador ambiental de mudanças no uso do solo na bacia experimental do alto rio Jardim - DF. In: Anais do Congresso Iberoamericano e do Caribe sobre Restauração Ecológica. Curitiba: SOBRADE - Sociedade Brasileira de Recuperação de Áreas Degradadas, 2009, 1-5p.

PEARSON, K. The grammar of science. London, J. M. Dent and Company. 1892.

PEIXOTO, J.P. OORT, A.H. Lê cycle de l'eau et le. La Recherche. Spé- cial: L'eau. v.21, p. 57079, 1990. In: REBOUÇAS, A. C. Água doce no mundo e no Brasil. Em Águas doces no Brasil: capital ecológico, uso e conservação. (Orgs. Rebouças, A. C., Braga, B. \& Tundisi, J.G.). São Paulo, Escrituras Editora. 1999. 717p.

PIMENTEL GOMES, F. Curso de Estatística Experimental. São Paulo: Nobel, 1985. 467p.

PONTES, C. H. C.; LASTORIA, G.; PEREIRA, J. S. Panorama atual da Legislação Brasileira com referência à gestão da Água Subterrânea. XVII Simpósio Brasileiro de Recursos Hídricos. 2007.

PROCEL, S. Contaminação por Nitrato e sua relação com o crescimento urbano no Sistema Aquífero Bauru em Presidente Prudente (SP). 2011. 132 f. Dissertação (Mestrado em Recursos Minerais e Hidrogeologia) - Instituto de Geociências, Universidade de São Paulo, São Paulo, 2011.

QUEIRÓZ, G. J. F. O papel do setor público na pesquisa agrícola de Goiás. In. PEREIRA, S. L.; XAVIER, C. L. (Org.). O agronegócio nas terras de Goiás. Uberlândia: EDUFU, 2003.

REATTO, A.; CORREIA, J. R.; SPERA, S. T.; CHAGAS, C. S.; MARTINS, E. S.; ANDAHUR, J. P.; GODOY, M. J.; ASSAD, M. L. C. L. Levantamento semidetalhado dos solos da Bacia do rio Jardim - DF, escala 1:50.000. Planaltina: Embrapa Cerrados. Boletim de pesquisa/ Embrapa Cerrados, ISSN 1518-0417; n. 18, 2000, 1-63p.

REGAZZI, A. J.; LEITE, H. G. Análise de regressão: teoria às aplicações em manejo florestal. Viçosa: UFV, 1992, 236p.

REIMANN, C.; FILZMOSER, P.; GARRETT R.; DUTTER R. Statistical data analysis explained. Applied environmental statistics with R. 1 ed. Chichester. Ed. John Wiley \& Sons, 2008. 362 p.

RESENDE, A. V. de. Agricultura e qualidade da água: contaminação da água por nitrato. Documentos/Embrapa Cerrados, ISSN 1517-5111; n.57 - Planaltina: Embrapa Cerrados, 2002. 29p.

RIBEIRO, A. L.; LOURENCETTI, C.; PEREIRA, S. Y.; MARCHI, M. R. R. de. Contaminação de águas subterrâneas por pesticidas: avaliação preliminar. Química Nova, Vol. 30, No. 3, 2007, 688$694 \mathrm{p}$. 
RIBEIRO, C. A. A. S.; SOARES, V. P.; SANTOS, R. M.; SOARES, C. P. B. Estruturação topológica de grandes bases de dados de bacias hidrográficas. Revista Árvore, v.32, n.4, 2008, 687$696 \mathrm{p}$.

SANTOS, G. A.; PEREIRA, A. B. \& KORNDÖRFER, G. H. Uso do sistema de análises por infravermelho próximo (NIR) para análises de matéria orgânica e fração argila em solos e teores foliares de silício e nitrogênio em cana-de-açúcar. In: FERRARESI, T. M., et al. Espectroscopia de infravermelho na determinação da textura do solo. Revista Brasileira de Ciência do Solo, 2012, 36:1769$1777 \mathrm{p}$.

SENRA, J. B.; VILELlA, W. M. C.; ANDRÉ, M. A. S. Legislação e Política Nacional de Recursos Hídricos. Simpósio Nacional sobre o Uso da Água na Agricultura. 2004.

SHALHEVET, J.; KAMBUROV, J. Irrigation and salinity: A worldwide Survey, 1976. In: JÚNIOR, A. S. de A.; SILVA, Ê. F. de F. e; BASTOS, E. A.; MELO, F. de B.; LEAL, C. M. Uso e qualidade da água subterrânea para irrigação no Semi- Árido Piauiense. Revista Brasileira de Engenharia Agrícola e Ambiental. Vol.10, n.4, 2006, 873-880p.

SILVA, D. B.; SIlVA, J. A; JUNQUEIRA, N. L. V.; ANDRADE, L. R. M. Frutas do Cerrado. Brasília: Embrapa Informação Tecnológica, 2001. 178p.

SOBRINHO, T. A.; OLIVEIRA, P. T. S.; RODRIGUES, D. B. B.; AYRES; F. M. Delimitação automática de bacias hidrográficas utilizando dados SRTM. Engenharia Agrícola, Jaboticabal, v.30, n.1, jan./fev. 2010, 46-57p.

SPERA, S. T. REATTO, A.; MARTINS, E. S.; CORREIA, J. R. Aptidão Agrícola das terras da bacia do rio Jardim, DF. Planaltina, DF: Embrapa Cerrados. Boletim de pesquisa e desenvolvimento/ Embrapa Cerrados, n. 27, 2002, 38p.

TARBOTON, D. G.; MOHAMMED, I. N. TauDEM 5.0. Terrain analysis using digital elevation models. Disponível em: <http://hydrology.usu.edu/taudem/taudem5/index.html>. Acessado em: 15.ago.2015.

TITO, F. M. P.; CANTO, E. L. do. Química na abordagem do Cotidiano. Volume único - 2. Ed. São Paulo: Moderna, 2002, 584p.

TODD, D. K. Hidrologia de águas subterrâneas. Editora Edgard Blucher LTDA. Missão Norteamericana de cooperação econômica e técnica no Brasil - USAID. São Paulo, 1959.

TUCCI, C. E. M.; CLARKE R. T. Impacto das mudanças da cobertura vegetal no escoamento: revisão. RBRH - Revista Brasileira de Recursos Hídricos, v. 2, n.1 Jan/Jun 1997, 135-152p.

TUNDISI, J. G. Limnologia no Século XXI: Perspectivas e Desafios. São Carlos, I. I. E. $7^{\circ}$ Congresso Brasileiro de Limnologia - SBL, Florianópolis, SC. 1999, 24p.

VALERIANO, M. M. Mapeamento da declividade em microbacias com sistemas de informação geográfica. Revista Brasileira de Engenharia Agrícola e Ambiental, v.7, n.2, 2003, 303-310p.

VASCONCELOS, N. S.; DANTAS NETO, J.; MEDEIROS, J. F. de; LIMA, C. J. G. S. Qualidade das águas subterrâneas de área irrigada da comunidade de Pau Branco em Mossoró (RN). HOLOS, Ano 29, Vol. 1, 2013.

VON SPERLING, M. Introdução à qualidade das águas e ao tratamento de esgotos. 3. Ed. Belo Horizonte: Departamento de Engenharia Sanitária e Ambiental, Universidade Federal de Minas Gerais, 2005. 452p.

YARON, B. Water suitability for irrigation, 1973. In: JÚNIOR, A. S. de A.; SILVA, Ê. F. de F. e; BASTOS, E. A.; MELO, F. de B.; LEAL, C. M. Uso e qualidade da água subterrânea para irrigação no Semi- Árido Piauiense. Revista Brasileira de Engenharia Agrícola e Ambiental. Vol.10, n.4, 2006, $873-880 \mathrm{p}$ 
ZENG, X., RASMUSSEN, T.,C. Multivariate statistical characterization of water quality in lake Lanier, Georgia, USA. J. Environ. Qual., 34, 2005. 1980-1991p.

ZUIN, V. G.; IORIATTI, M. C. S.; MATHEUS, C. E. O emprego de parâmetros físicos e químicos para a avaliação da qualidade de águas naturais. Química Nova na escola, 31 (1), 2009, 3$8 p$. 